Eduardo Terenzi Stuchi

\title{
INTERFERÊNCIAS DE OBRAS DE SERVIÇO DE ÁGUA E ESGOTO SOBRE O DESEMPENHO DE PAVIMENTOS URBANOS.
}

Dissertação apresentada à Escola de Engenharia de São Carlos, da Universidade de São Paulo, como parte dos requisitos para a obtenção do título de Mestre em Engenharia Civil: Transportes.

Orientador: Prof. Dr. José Leomar Fernandes Júnior

São Carlos 2005 
Aos meus pais,

a quem devo tudo o que sou na vida, e às minhas irmãs e cunhado pelo apoio na construção do meu futuro. 


\section{AGRADECIMENTOS}

Ao Prof. Dr. José Leomar Fernandes Júnior, a sabedoria, atenção e amizade na orientação desta pesquisa.

À Profa. Dra. Eliane Viviani e ao Prof. Dr. Wellington Cyro de Almeida Leite, pelas valiosas sugestões quando do Exame de Qualificação.

Ao Conselho Nacional de Desenvolvimento Científico e Tecnológico - CNPq, pela bolsa de estudo concedida.

Ao Serviço Autônomo de Água e Esgoto (SAAE) de São Carlos, em especial ao Engenheiro Frank Willian Buzzérif, e ao Departamento Autônomo de Água e Esgoto (DAAE) de Araraquara, em especial ao Gerente de Manutenção e Obras Arnaldo Salvador Felício, pelo fornecimento dos dados.

Aos amigos da Pós-Graduação, em especial Fabio, Marcos, Frederico, Deise, Josiane, Simone, Leonardo, Ernesto, Marcelo, Pablo e Shirley.

Aos alunos da Graduação Laura e João, pela amizade e ajuda direta para a realização deste trabalho.

Aos amigos Caio Rubes, Ana Paula Furlan e Cira Pitombo pelo caráter e pela duradoura e inabalável amizade. 
Aos Professores do Departamento de Transportes, que muito contribuíram para minha formação, em especial aos professores Glauco, Parreira e Manoel.

Aos funcionários do STT: Heloisa, Beth, Magali, Carlos (Toco), Gigante, Paulo e João pela cooperação e incentivo.

A todos os outros que direta ou indiretamente colaboraram para a execução desse trabalho e por algum motivo não foram lembrados. 
"Algo só é impossível até que alguém duvide e acabe provando o contrário." (Albert Einstein)

"A mente que se abre a uma nova idéia jamais voltará a seu tamanho original." (Albert Einstein)

"O que sabemos é uma gota, o que ignoramos é um oceano."

(Isaac Newton) 


\section{RESUMO}

STUCHI, E.T. (2005). Interferências de obras de serviço de água e esgoto sobre o desempenho de pavimentos urbanos. Dissertação (Mestrado) - Escola de Engenharia de São Carlos, Universidade de São Paulo, São Carlos, 2005.

Apresenta-se um estudo de caso realizado nas cidades de São Carlos e Araraquara, Estado de São Paulo, em que são analisados problemas nos pavimentos associados aos serviços de manutenção da infra-estrutura de água e esgoto, tanto em nível de rede como em nível de projeto. Investiga-se a possibilidade de compatibilização da gerência de pavimentos com a gerência de outras infra-estruturas e analisam-se as normas dos serviços, os métodos de execução efetivamente utilizados e os procedimentos de controle e garantia da qualidade. Os resultados mostram a necessidade de implementação de sistemas racionais de gerenciamento de infra-estruturas pelas prefeituras e concessionárias de serviços públicos e o desenvolvimento de regulamentações, manuais e guias para restauração dos pavimentos após os serviços de manutenção das redes, com um controle mais rigoroso dos procedimentos técnicos.

Palavras-chave: sistemas de gerência; infra-estrutura urbana; pavimentos; sistemas de água e esgoto; 


\section{ABSTRACT}

STUCHI, E.T. (2005). Effects of the Maintenance of Water and Sewer Networks on Urban Pavement Performance. M.Sc. Dissertation - Escola de Engenharia de São Carlos, Universidade de São Paulo, São Carlos, 2005.

It is presented a case study performed in the cities of Sao Carlos and Araraquara, State of Sao Paulo, Brazil. It analyses pavement problems associated to the maintenance of water and sewer infrastructure networks at both network and project levels. It investigates the possibilities of integration of the pavement management to the management of other infrastructures and it analyses the service regulations, the construction methods effectively used and the quality control/quality assurance (QC/QA) procedures. The results show the necessity of the implementation of a rational infrastructure management system by the cities and urban agencies, and the development of regulations, manuals and guidelines for pavement restoration after the maintenance of water and sewer networks, which will allow a more effective enforcement of the technical standards.

Keywords: management systems; urban infrastructure; pavements; water and sewer networks 


\section{LISTA DE FIGURAS}

Figura 2.1 - Exemplos de interferências das infra-estruturas urbanas na via pública (adaptada de AL-SWAILMI, 1994).

Figura 2.2- Sistema viário (COMGAS, 2004).

Figura 2.3- Redes e equipamentos de infra-estrutura (COMGAS, 2004).

9

Figura 2.4 - Plataforma para um sistema de manutenção da infraestrutura urbana (adaptada de AL-SWAILMI, 1994).

Figura 2.5 - Exemplo de utilização desordenada do subleito de uma via urbana (MISAWA et al., 1975).

Figura 3.1 - Intervenções sucessivas no pavimento, relacionadas às infra-estruturas urbanas.

Figura 3.2 - Execução de sinalização de segurança (ABES, 1978).

Figura 3.3 - Sinalizações utilizadas nas obras em vias públicas urbanas (ABES, 1978).

Figura 3.4 - Marcação de vala para ligação de água (ABES, 1978).

Figura 3.5 - Rompimento e remoção de pavimento (ABES, 1978).

Figura 3.6 - Abertura de vala (ABES, 1978).

Figura 3.7 - Esgotamento: lastro de brita e canaletas (Nina, 1966).

Figura 3.8 - Caixa de segurança (Nina, 1966). 
Figura 3.9 - Reaterro de vala (ABES, 1978).

Figura 3.10 - Reposição do pavimento (ABES, 1978).

Figura 3.11 - Procedimentos para execução de um remendo permanente (SHRP, 1993a).

Figura 3.12 - Exemplo de gráfico para comparação do desempenho de diferentes formas de deterioração (SHRP, 1993a).

Figura 3.13 - Defeitos devidos à execução inadequada (Augusto Jr. et al., 1992).

Figura 4.1 - Fluxograma dos componentes de um sistema de gerência de pavimentos em nível de rede e projeto (Haas et al. 1994).

Figura 4.2- Etapas da implantação de um SGPU (MAPC, 1986).

Figura 4.3 - Conceito de serventia-desempenho (CAREY \& IRICK, 1960).

Figura 4.4 - Mapa temático contendo índices de prioridades de algumas seções da cidade de São Carlos (Zanchetta, 2005).

Figura 4.5 - Excesso de interferência do SAAE. (Zanchetta, 2005).

Figura 5.1- Localização das Cidades de São Carlos e Araraquara.

Figura 5.2- Sistema viário de São Carlos.

Figura 5.3 - Demarcação do corte.

Figura 5.4 - Corte do revestimento asfáltico.

Figura 5.5 - Remoção do material existente.

Figura 5.6 - Regularização da área.

Figura 5.7 - Colocação da brita, após compactação.

Figura 5.8 - Compactação da brita graduada.

Figura 5.9 - Aplicação da pintura de ligação.

Figura 5.10 - Aplicação do revestimento.

Figura 5.11 - Regularização do revestimento. 
Figura 5.13 - Compactação das laterais do revestimento. 70

Figura 5.14 - Resultado final da execução. 70

Figura 5.15- Sistema viário de Araraquara. $\quad 71$

Figura 5.16 - Sistema de Informações Geográficas para Empresas de Saneamento (Geoprocessamento). 73

Figura 5.17 -Geração automática de Overlays (planta-quadra). 75

Figura 5.28 - Nós de rede com fotos das peças e ou símbolos ABNT. 75

Figura 5.19 - Visualização de ortofotocartas. $\quad 76$

Figura 5.20 - Rastreio de veículos operacionais e administrativos via GPS. 76

Figura 5.21 - Visualização dos dados de consumo e pendências de um consumidor a partir da localização no mapa. $\quad 76$

Figura 5.22 - Lista de execução diária de ordens de serviços (SAAE). $\quad 80$

Figura 5.23 - Localização das ligações do SAAE (2002-2004). 82

Figura 5.24 - Recalque do pavimento reconstituído. 84

Figura 5.25 - Deterioração das áreas do pavimento próximo à vala. 85 


\section{LISTA DE TABELAS}

Tabela 2.1 - Participação média, em porcentagem, das diferentes partes nos custos totais dos subsistemas urbanos (Mascaró, 1989).

22

Tabela 2.2 - Participação, em porcentagem, de cada rede no custo total (Mascaró, 1989).

Tabela 4.1 - Identificação de defeitos nos pavimentos (SHRP, 1993b).

Tabela 4.2 - Distribuição percentual da condição dos pavimentos e das estratégias de M\&R (Zanchetta, 2005).

Tabela 4.3 - Resumo dos defeitos presentes na malha urbana de São Carlos (Zanchetta, 2005).

Tabela 4.4 - Intervenção no pavimento (Zanchetta, 2005).

Tabela 5.1 - Ligações executadas pelo SAAE em 2002.

Tabela 5.2 - Ligações executadas pelo SAAE em 2003.

Tabela 5.3 - Ligações executadas pelo SAAE em 2004.

Tabela 5.4 - Ligações executadas pelo SAAE (2002-2004). 


\section{LISTA DE ABREVIATURAS}

ABES - Associação Brasileira de Engenharia Sanitária e Ambiental CBUQ - Concreto Betuminoso Usinado a Quente CONVIAS - Departamento de Controle de Usos das Vias Públicas

DAAE - Departamento Autônomo de Água e Esgoto

DAEE - Departamento de Águas e Energia Estadual

ETE - Estação de Tratamento de Efluentes

ICP - Índice de Condição do Pavimento

IP - Índice de Prioridade

M\&R - Manutenção e Reabilitação

MC - Manutenção Corretiva

MP - Manutenção Preventiva

PEAD - Polietileno de Alta Densidade

PMA - Prefeitura Municipal de Araraquara

PMSC - Prefeitura Municipal de São Carlos

PMF - Pré-Misturado a Frio

PMSP - Prefeitura Municipal de São Paulo

SAAE - Serviço Autônomo de Água e Esgoto

SGP - Sistema de Gerencia de Pavimentos

SGPU - Sistema de Gerencia de Pavimentos Urbanos

SHRP - Strategic Highway Research Program

SIG - Sistema de Informação Geográfica

SMTTVP - Secretaria Municipal de Transporte, Trânsito e Vias Públicas 


\section{SUMÁRIO}

1 - INTRODUÇÃO

$1.1-$ OBJetivos 3

1.2 - ESTRUTURA DO TRABALHO 3

2 - INFRA-ESTRUTURA URBANA

2.1 - INTRODUÇÃO

2.2 - As RedEs SEgundo SUA FunÇÃo

2.2.1 - Sistema Viário 8

2.2.2 - Sistema de Drenagem Pluvial 11

2.2.3 - Sistema de Abastecimento de Água 12

2.2.4 - Sistema de Esgoto Sanitário 14

2.2.5 - Sistema de Energia Elétrica 16

2.2.6 - Sistema de Energia a Gás 18

2.2.7 - Sistema de Comunicações 18

2.3 - As REDES SEGUNDO SUA LOCALIZAÇÃO 19

2.3.1 - Nível Aéreo 19

2.3.2 - Nível da Superfície do Terreno 20

2.3.3 - Nível Subterrâneo 20

2.4 - CUSTOS DOS SISTEMAS DE INFRA-ESTRUTURA URBANA 21

2.5 - GERÊNCIA DE INFRA-ESTRUTURA URBANA 23 
$\begin{array}{ll}3.1-\text { INTRODUÇÃO } & 27\end{array}$

3.2 - AS FASES DA INFRA-ESTRUTURA URBANA 28

3.2.1 - Sinalização $\quad 29$

3.2.2 - Remoção da pavimentação 31

3.2.3 - Abertura de valas 32

3.2.4 - Esgotamento 34

3.2.5 - Escoramento 35

3.2.6 - Instalação 36

3.2.7 - Fechamento das valas $\quad 36$

$\begin{array}{ll}3.2 .8 \text { - Reconstrução do pavimento } & 37\end{array}$

3.3 - EXECUÇÃO DE REMENDOS 38

3.3.1 - Remendo Simples 39

3.3.2 - Remendo Compactado $\quad 39$

3.3.3 - Remendo Permanente $\quad 39$

3.3.4 - Avaliação dos Remendos 40

3.3.5 - Desempenho dos remendos 41

3.4 - DEFEITOS DEVIDO À EXECUÇÃO IMPERFEITA 42

3.5 - PRocesso de REPARO ADEQUADO 44

4 -GERÊNCIA DE PAVIMENTOS URBANOS 45

4.1 - INTRODUÇÃO

4.2 - DeSENVOLVIMENTO DE UM SGPU 47

4.2.1 - Inventário 48

4.2.2 - Avaliação da condição dos pavimentos $\quad 49$

4.2.3 - Priorização 51

4.2.4 - Atividades de manutenção e reabilitação 53

4.3 - SGPU NA CIDADE DE SÃo CARLOS - SP 53

5 - ESTUDO DE CASO 57

5.1 - INTRODUÇÃO

5.2 - A CIDADE DE SÃo CARLOS $\quad 59$ 
5.2.1 - Secretaria Municipal de Transporte, Trânsito e Vias Públicas

5.2.2 - Serviço Autônomo de Água e Esgoto

5.2.3 - Coleta dos dados - SAAE São Carlos

5.3 - A CIDADE DE ARARAQUARA

5.3.1 - Departamento Autônomo de Água e Esgoto 72

5.3.2 - Coleta dos dados - DAAE Araraquara 77

5.4 - ANALISE DOS DADOS $\quad 79$

5.4.1 - Nível de Rede $\quad 80$

5.4.2 - Nível de Projeto $\quad 83$

6 - CONCLUSÕES E CONSIDERAÇÕES 87

$\begin{array}{ll}6.1-\text { CONCLUSÕES } & 87\end{array}$

6.2 - SUGESTÕES PARA TRABALHOS FUtUROS 89

7 - REFERÊNCIA BIBLIOGRÁFICA 90

ANEXO A - INSTRUÇÕES DE REPARAÇÃO DE PAVIMENTOS FLEXÍVEIS DANIFICADOS POR ABERTURA DE VALAS 96

ANEXO B - INSTRUÇÕES DE REPARAÇÃO DE PAVIMENTOS DE CONCRETO DANIFICADOS POR ABERTURA DE VALAS 108

ANEXO C - INSTRUÇÕES DE REPARAÇÃO DE PAVIMENTOS ARTICULADOS DANIFICADOS POR ABERTURA DE VALAS 118 


\section{1 - INTRODUÇÃO}

As atividades de pavimentação surgiram com a necessidade de se melhorar o tráfego nas estradas e ruas sob qualquer condição climática. Com a evolução dos veículos e o aumento do tráfego, tornou-se inevitável o aperfeiçoamento da técnica de pavimentação. Acrescentaram-se às funções iniciais de conforto e segurança, as funções estruturais, de resistir às cargas por tempos cada vez maiores.

Motta (1995) considera que a importância da pavimentação das vias urbanas é bastante clara, para a maioria dos técnicos, políticos ou usuários, embora por motivações diversas. No entanto, a importância da fase seguinte, que é a manutenção das vias construídas, não é tão evidente para a maioria daqueles que têm o poder decisório nas mãos, apesar de representar vida nova às obras, preservação de vidas humanas, ao evitar acidentes, e preservação ecológica, em função de menores gastos com combustível.

Segundo Fernandes Jr., Margarido e Zerbini (1996), os recursos para manutenção e reabilitação de pavimentos são geralmente inferiores às necessidades. Dessa forma, devem ser utilizados da maneira mais eficiente possível. Um sistema de gerência de pavimentos (SGP) é a ferramenta que pode ajudar os organismos rodoviários na melhor utilização dos recursos.

Conforme apresentado por Haas, Hudson e Zaniewski (1994), um sistema de gerência de pavimentos consiste de um elenco de atividades 
coordenadas, relacionadas com o planejamento, projeto, construção, manutenção, avaliação e pesquisa de pavimentos.

Embora os princípios da gerência de pavimentos sejam os mesmos para todos os organismos rodoviários, as agências municipais têm, normalmente, menos recursos. Os sistemas de gerência de pavimentos urbanos utilizam, geralmente, a técnica de priorização para a seleção de projetos e não a otimização, normalmente utilizada pelas agências federais e estaduais, e são menos sofisticados, o que facilita o entendimento e utilização por parte dos engenheiros municipais.

Dentre as diferenças entre os pavimentos de vias interurbanas e os pavimentos urbanos, merecem destaques ainda:

- menores velocidades de tráfego;

- paradas freqüentes nas interseções;

- interferências de instalações subterrâneas de outras modalidades de infra-estrutura urbana (concessionárias de serviço público).

Para Paolucci e Carvalho (1995), a pavimentação de vias urbanas é, normalmente, o alvo das atenções e fica em primeiro plano no cronograma de execução. Já as redes de esgoto e de abastecimento de água, por serem obras enterradas e, portanto, não visíveis aos olhos da população, são sempre colocadas em segundo plano. No entanto, as obras de saneamento tornam-se, com o tempo, indispensáveis, acabando por serem implementadas e fazendo com que o pavimento muitas vezes há pouco executado, seja parcialmente destruído, o que gera custos de recuperação e diminui a sua função operacional e estrutural.

Não só em São Carlos e Araraquara, mas em quase todas as cidades de médio porte do interior do Estado de São Paulo, grande parte dos problemas dos pavimentos está diretamente associada à má qualidade dos serviços de reparo de outras infra-estruturas urbanas, que dão ao usuário uma sensação de grande desconforto, além de enfraquecer a estrutura do pavimento.

Este trabalho fundamenta-se em uma avaliação de intervenções feitas nos pavimentos por obras de serviço de água e esgoto, a partir da análise de dados coletados através do acompanhamento dos serviços de ligação e 
manutenção feitos pelo Serviço Autônomo de Água e Esgoto (SAAE) na cidade de São Carlos, e pelo Departamento Autônomo de Água e Esgoto (DAAE) na cidade de Araraquara. Optou-se por esse tipo de rede devido ao grande número de interferência que são realizadas quando comparadas com as outras redes de infra-estrutura urbana.

\section{1 - OBJETIVOS}

O objetivo do trabalho consiste em identificar alternativas para solucionar os problemas de pavimentação urbana causados por intervenções dos sistemas de infra-estrutura. Em nível de rede, pretende-se analisar possibilidades de compatibilizar a gerência de pavimentos com a gerência de outras infra-estruturas urbanas. E, em nível de projeto, analisar as normas de execução dos serviços, os métodos de execução efetivamente utilizados e os critérios de recebimento dos serviços.

\section{2 - ESTRUTURA DO TRABALHO}

O presente trabalho encontra-se dividido em 6 capítulos. Após a introdução apresentada nesta seção, o Capítulo 2 trata das redes de infraestrutura urbana, classificando-as segundo sua função e localização, sendo feita uma análise de custo desses sistemas. É feito ainda um breve comentário sobre gerência de infra-estrutura urbana, levando-se em consideração o controle de uso das vias públicas. Descrevem-se, no Capítulo 3, alguns detalhes sobre as interferências de infra-estrutura urbana, apresentando-se fases da interferência de infra-estrutura desde a abertura da vala até a reposição da pavimentação. No Capítulo 4, discutem-se aspectos gerais da Gerência de Pavimentos Urbanos. Apresenta-se, no Capítulo 5, o estudo de caso conduzido nas cidades de São Carlos e Araraquara, seguido das conclusões e recomendações, contidas no Capítulo 6. Finalmente, são apresentadas as referências bibliográficas. 
Deste trabalho constam, ainda, três anexos: no Anexo A são mostradas instruções de reparação de pavimentos flexíveis danificados por abertura de valas; no Anexo B são mostradas instruções de reparação de pavimentos de concreto danificados por abertura de valas; e no Anexo C são mostradas instruções de reparação de pavimentos articulados danificados por abertura de valas. 


\section{2 - INFRA-ESTRUTURA URBANA}

\section{1 - INTRODUÇÃO}

O espaço urbano não é constituído simplesmente pela tradicional combinação de áreas edificadas e áreas livres, interligadas através dos sistemas viários. As redes de infra-estrutura também fazem parte do espaço urbano e o pleno desenvolvimento das cidades está diretamente relacionado a elas. Através da sua existência, melhoram-se as condições ambientais e de produção e, conseqüentemente, a qualidade de vida da população.

A rede viária, de drenagem pluvial, de abastecimento de água e a de esgoto sanitário são as redes básicas que fazem com que um determinado núcleo urbano se torne operacional. Historicamente, essas redes foram as primeiras a surgir e tiveram origem praticamente na mesma época do surgimento das cidades.

No caso do saneamento, é evidente que a implantação de redes de abastecimento de água e coleta de esgotos é imprescindível. Segundo Nucci (1983), a demanda por água pode ser estipulada pela necessidade de saúde, insumo de produção ou bem de consumo, assim como a coleta de esgotos funciona como um agente de qualidade ambiental.

As redes de energia, tanto a gás como a elétrica, surgiram no século XIX. As de gás primeiramente com a função de iluminação e, posteriormente, de consumo nos fogões e aquecimento. As redes de energia elétrica surgiram 
em fins do século XIX, a princípio para fins de iluminação, substituindo as instalações a gás, e posteriormente ampliando sua utilização para eletrificação de meios de transporte e na indústria.

O uso da energia elétrica e a gás canalizado, além de favorecer aspectos de comodidade e segurança, é a base de apoio à produção, alimentando indústrias e o comércio. Conforme enfatiza Mascaro (1987), as redes de gás e eletricidade permitem que as cidades mudem de função e passem de centros administrativos ou de intercâmbio a centros de produção.

O século $X X$ caracterizou-se como o século das telecomunicações. As redes de telefonia, a invenção da fibra ótica, a televisão convencional e a televisão a cabo são reflexos dos meios modernos de redes que ampliam o espaço urbano e vão além deles.

A expansão da rede de telefonia fixa e móvel e dos telefones públicos capazes de receber chamadas diminuiu a distância entre pessoas, possibilitando, até aos menos favorecidos, a sensação de estar incluídos no processo de desenvolvimento tecnológico.

O sistema de cabos óticos, base do funcionamento das televisões a cabo e da Internet, vem assumindo importante papel na inserção do país em negócios com o mundo e traz, aos que podem usufruir de seus serviços, mais informação e cultura. Esse sistema também propicia a substituição dos cabos convencionais para ligações de energia elétrica e telefonia, diminuindo o diâmetro e número de cabos utilizados para a expansão dessas redes.

Segundo Zmitrowicz e Angelis Neto (1997), a infra-estrutura urbana pode ser conceituada como um sistema técnico de equipamentos e serviços necessários ao desenvolvimento das funções urbanas, podendo essas funções ser vistas sob os aspectos social, econômico e institucional. Sob o aspecto social, a infra-estrutura urbana visa promover adequadas condições de moradia, trabalho, saúde, educação, lazer e segurança. No que se refere ao aspecto econômico, a infra-estrutura urbana deve propiciar o desenvolvimento das atividades produtivas, isto é, a produção e comercialização de bens e serviços. E sob o aspecto institucional, entende-se que a infra-estrutura urbana 
deva propiciar os meios necessários ao desenvolvimento das atividades político-administrativas, entre as quais se inclui a gerência da própria cidade.

$\mathrm{Na}$ realidade, o sistema de infra-estrutura urbana é composto de subsistemas e cada um deles tem como objetivo final a prestação de um serviço, o que é fácil de perceber quando se nota que qualquer tipo de infraestrutura requer, em maior ou menor grau, algum tipo de operação e alguma relação com o usuário, o que caracteriza a prestação de um serviço. Por outro lado, ainda que o objetivo dos subsistemas de infra-estrutura seja a prestação de serviços, sempre há a necessidade de investimentos em bens ou equipamentos, que podem ser edifícios, máquinas, redes de tubulações ou galerias, túneis e vias de acesso, entre outros.

O sistema de redes de infra-estrutura de uma cidade pode ser dividido, para sua melhor compreensão, em vários subsistemas ou sistemas parciais. Um critério de classificação das diferentes redes é o que leva em consideração a sua função, sendo uma classificação alternativa a que as organiza segundo sua posição no espaço urbano.

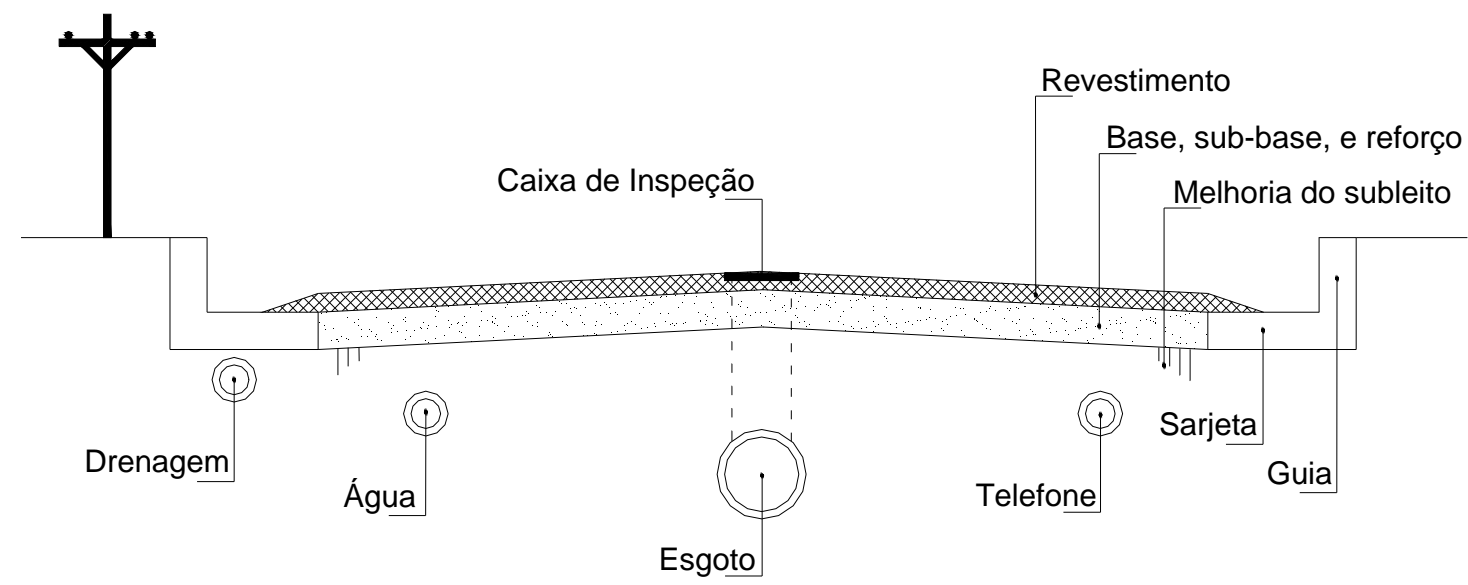

Figura 2.1- Exemplos de interferências das infra-estruturas urbanas na via pública (adaptada de AL-SWAILMI, 1994). 


\section{2 - As REDES SEGUNDO SUA FUNÇÃO}

A engenharia urbana é a arte de conceber, realizar e gerenciar sistemas técnicos. A classificação a seguir reflete a visão de como a cidade funciona e todos os sistemas técnicos a seguir relacionados são denominados, no seu conjunto, de sistemas de infra-estrutura urbana:

- Sistema Viário: consiste das vias urbanas;

- Sistema de Drenagem Pluvial;

- Sistema de Abastecimento de Água;

- Sistema de Esgoto Sanitário;

- Sistema de Energia Elétrica;

- Sistema de Energia a Gás;

- Sistema de Comunicações.

\subsection{1 - SISTEMA VIÁRIO}

Segundo Mascaró (1987), de todos os sistemas, o viário é o mais representativo, merecendo estudos cuidadosos porque: é o mais caro do conjunto de sistemas, já que normalmente abrange mais de $50 \%$ do custo total de urbanização; ocupa uma parcela importante do solo urbano (entre 20 e 25\%); uma vez implantado, é o sistema que mais dificuldade apresenta para aumentar sua capacidade pela área que ocupa, pelos custos que envolve e pelas dificuldades operacionais que cria sua alteração; é o sistema que está mais vinculado aos usuários (conduz pessoas).

O sistema viário (Figura 2.2) é composto de uma ou mais redes de circulação, de acordo com o tipo de espaço urbano (para receber veículos automotores, bicicletas, pedestres, entre outros). Complementa este sistema o sistema de drenagem de águas pluviais (que será visto mais adiante), que assegura ao viário o seu uso sob quaisquer condições climáticas. 


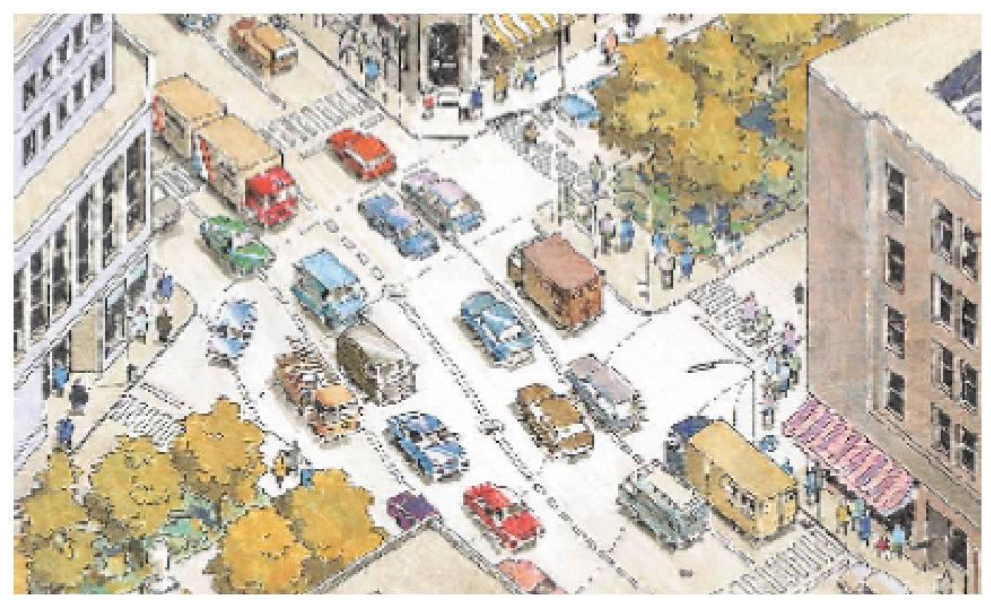

Figura 2.2- Sistema viário (COMGAS, 2004).

Além disso, as vias, que constituem o sistema viário, contêm as redes e equipamentos de infra-estrutura que compõem seus demais sistemas, em menor ou maior escala (Figura 2.3).

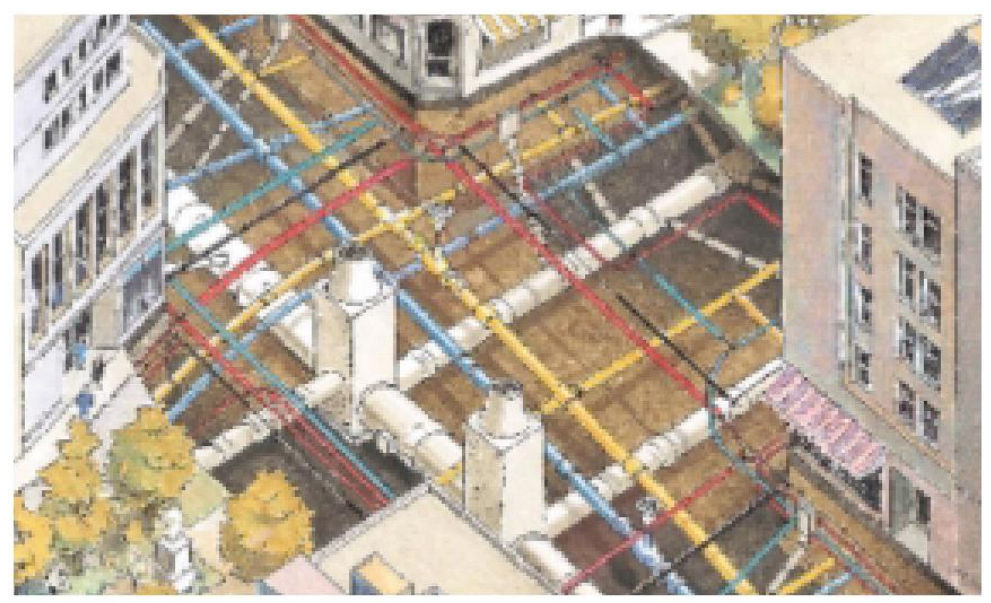

Figura 2.3- Redes e equipamentos de infra-estrutura (COMGAS, 2004).

Podem ser encontradas vias de diversas dimensões e padrões, em função do volume, velocidade e intensidade do tráfego, sentido do fluxo (que pode ser unidirecional ou bidirecional) e das interferências que pode ter 0 tráfego, tais como cruzamentos, estacionamentos e garagens. Em função desses fatores, as vias podem ser classificadas em: Vias Locais; Vias Coletoras; Vias Arteriais; e Vias Expressas (Mascaró, 1987). 
- Vias Locais: apresentam utilização mista, isto é, são utilizadas tanto por veículos como por pedestres, sendo que os veículos são, predominantemente, os dos próprios moradores da rua;

- Vias Coletoras: ligam vias locais de setores ou bairros com as vias arteriais e servem também ao tráfego de veículos de transporte coletivo;

- Vias Arteriais: são, em geral, denominadas avenidas, interligam áreas distantes; podem possuir volume e velocidade de tráfego elevados e suas pistas são unidirecionais;

- Vias Expressas: são de alta velocidade, unidirecionais, possuem poucos cruzamentos e podem ter, também, mais de duas pistas de rolamento e acostamento, não sendo indicadas para tráfego de pedestres.

Deve-se destacar que existem cidades que utilizam mais classes (Porto Alegre, por exemplo, tem 9 classes) e outras, pela falta de estudos mais detalhados, têm apenas três classes (local, coletora e arterial).

Devido ao grande desembolso necessário para a implantação das vias que compõem o sistema viário, a manutenção das mesmas reveste-se de grande importância. A manutenção pode ser considerada de duas formas: Manutenção Preventiva e Manutenção Corretiva.

A Manutenção Preventiva apresenta, geralmente, custos relativamente baixos e visa permitir o bom funcionamento da via durante a vida em serviço projetada. Pinturas periódicas das faixas, verificação e troca de placas de sinalização danificadas, pequenos reparos nas pistas e limpeza da faixa de domínio fazem parte desta forma de manutenção.

Já a Manutenção Corretiva é necessária quando a via se apresenta danificada por agentes de tráfego (automóveis, ônibus, caminhões) ou por agentes naturais (inundações, escorregamentos de aterros) que impeçam ou dificultem o trânsito normal na mesma. As patologias mais comuns são: buracos na pista, destruição das proteções laterais e deterioração dos pavimentos, entre outros. 


\subsection{2 - Sistema DE Drenagem PluVial}

Em relação às outras redes de infra-estrutura urbana, o sistema de drenagem tem uma particularidade: o escoamento de águas pluviais sempre ocorrerá, independentemente de existir ou não sistema de drenagem adequado. A qualidade do sistema é que determinará se os benefícios ou prejuízos à população serão maiores ou menores. Basta dizer que, quando bem projetado, o sistema de drenagem elimina praticamente as inundações na área urbana, evitando as interferências no tráfego de pedestres e veículos, eliminando os danos às propriedades e reduzindo, também, a deterioração dos pavimentos das vias.

As vias pavimentadas, incluindo-se aí as guias e sarjetas, constituem o primeiro elemento de drenagem. Além de sua função primordial, que é permitir o tráfego de veículos e de pedestres, as vias servem a um importante papel na drenagem urbana, que é a coleta e condução das águas pluviais. Um bom projeto de drenagem proporciona benefícios diretos ao tráfego e menores custos de manutenção das vias. A drenagem deve ter a função de complementar a rede viária, protegendo-a e aumentando sua vida útil, pois a remoção eficiente das águas pluviais da superfície do pavimento tem um efeito positivo na manutenção da via.

Segundo Mascaró (1989), os elementos que fazem parte do sistema de drenagem de águas pluviais são: Meios-Fios ou Guias; Sarjetas; Sarjetões; Bocas-de-lobo; Galerias; Poços de Visitas e Bacias de Estocagem.

Os Meios-Fios ou Guias são elementos utilizados entre o passeio e o leito carroçável, dispostos paralelamente ao eixo da rua, formando um conjunto com as sarjetas. É recomendável que possuam uma altura aproximada de $15 \mathrm{~cm}$ em relação ao nível superior da sarjeta, para assegurar a abertura das portas dos automóveis e, além disso, conduzir as águas das vias.

As Sarjetas são faixas do leito carroçável, situadas junto ao meio-fio, formando canais triangulares cuja finalidade é receber e dirigir as águas pluviais para o sistema de captação. 
Os Sarjetões são calhas em forma de "V", situadas nos cruzamentos e que dirigem o fluxo de águas perpendiculares às vias. Um dos pontos críticos do sistema de drenagem pluvial ocorre nos cruzamentos de ruas, onde as águas, dentro do possível, não devem atrapalhar o tráfego.

As Bocas-de-lobo são caixas de captação das águas, colocadas ao longo das sarjetas, com a finalidade de captar as águas pluviais em escoamento superficial e conduzi-las ao interior das galerias. Normalmente, são localizadas nos cruzamentos das vias, a montante da faixa de pedestres, ou em pontos intermediários, quando a capacidade do conjunto meio-fio sarjeta fica esgotada.

As Galerias são canalizações destinadas a receber as águas pluviais captadas na superfície e encaminhá-las ao seu destino final.

Os Poços de Visitas são elementos do subsistema de drenagem de águas pluviais que possibilitam o acesso às canalizações, para limpeza e inspeção. São necessários quando há mudança de direção ou declividade na galeria, nas junções de galerias, na extremidade de montante, ou quando há mudança de diâmetro das galerias.

As Bacias de Estocagem são reservatórios superficiais ou subterrâneos que, ao acumular o excesso de água proveniente de chuvas fortes, permitem o escoamento pelas galerias ou canais existentes, em fluxos compatíveis com as capacidades, evitando extravasamentos sobre os leitos viários nos fundos de vale.

\subsection{3 - Sistema de AbAstecimento de ÁguA}

O sistema de abastecimento de água tem a função de suprir as necessidades diárias de água potável dos habitantes. Segundo Puppi (1981), a qualidade e a quantidade da água são as duas condições primordiais a serem observadas. A água potável, isto é, a que perfaz determinados requisitos físicos, químicos e biológicos, no Brasil, é praticamente a única a ser oferecida 
à população, para todos os usos, mesmo para aqueles em que águas de qualidade inferior poderiam ser admitidas sem riscos sanitários.

Segundo Mascaró (1987), a água destinada à bebida e alimentação é a que apresenta maior exigência de qualidade, sendo elevado seu custo de potabilização. Este problema tem sido resolvido, em alguns casos, pelo uso de purificadores domiciliares, solução parcial e elitista do problema. Em outros casos (pouco comum no Brasil), pela construção de duas redes de água, uma potável e outra para rega, enchimento de piscinas, uso industrial, incêndio, entre outros.

O sistema de abastecimento de água compõe-se, geralmente, das seguintes partes: Captação; Adutora; Estação Elevatória; Estação de Tratamento; Reservatórios e Redes de Distribuição.

O processo de Captação consiste de um conjunto de estruturas e dispositivos construídos junto a um manancial para a captação de água destinada a esse subsistema. Os mananciais utilizados para o abastecimento podem ser as águas superficiais (rios, lagos e córregos) ou subterrâneas.

A Adutora é constituído pelo conjunto de peças especiais e obras de arte destinadas a ligar as fontes de água bruta (mananciais) às estações de tratamento, e estas aos reservatórios de distribuição. Os materiais normalmente utilizados em adutoras são concreto, ferro fundido ou aço.

A Estação Elevatória é a unidade destinada a abrigar os conjuntos de recalque (bombas) e dispositivos complementares, tais como salão de máquinas, poços de sucção, tubulações, equipamento elétrico etc. É através dessas instalações que a água é conduzida a pontos distantes ou elevados.

É na Estação de Tratamento que a água se torna adequada ao consumo, ao passar por processos de purificação, até a obtenção da qualidade desejada.

Os Reservatórios destinam-se a armazenar a água já tratada e que será distribuída a setores específicos da cidade.

A Rede de Distribuição é a parte propriamente urbana e a mais dispendiosa de todo esse subsistema. Com os seus ramais instalados ao longo 
das ruas e logradouros públicos, a interdependência entre a rede hidráulica e a rede viária requer um cuidadoso estudo no planejamento urbanístico. Geralmente, sua instalação ocorre em uma cidade ou zona urbana préexistente, ficando seu traçado subordinado à configuração das vias públicas, nem sempre favorável a um melhor escoamento. As redes são constituídas por uma seqüência de tubulações de diâmetros decrescentes, com início no reservatório de distribuição. Peças de conexão dos trechos ou ramais, válvulas, registros, hidrantes, aparelhos medidores e outros acessórios completam-na.

Os materiais mais freqüentemente empregados nas tubulações que compõem o subsistema de distribuição são o ferro fundido e o PVC. Eles são utilizados em função das qualidades mínimas necessárias ao funcionamento das redes (pressões interna e externa, qualidade da água transportada, principalmente antes do tratamento, entre outras), acarretando, assim, menores custos de instalação e operação. Outro aspecto importante para se obter economia na execução e manutenção das redes é a profundidade de colocação das tubulações. Recomenda-se que as tubulações não sejam colocadas em grandes profundidades, já que as de esgotos devem estar sempre abaixo da rede de distribuição de água, por razões de segurança e higiene (Puppi,1981).

\subsection{4 - SISTEMA DE ESGOTO SANITÁRIO}

O sistema urbano de esgotos sanitários é um melhoramento que se impõe como seqüência lógica da implantação do serviço de abastecimento de água. Enquanto não é feita a distribuição de água, as condições de vida são precárias e a população é obrigada a adotar soluções mais elementares, tais como fossas séptica, para a disposição dos resíduos.

Uma vez utilizada, a água distribuída à população se deteriora, tornando-se repulsiva aos sentidos, imprestável mesmo a usos secundários, e nociva, em conseqüência da poluição e da contaminação. O seu imediato afastamento e um destino tal que não venha a comprometer a salubridade ambiental são providências que não podem ser postergadas (Puppi, 1981). 
Nas cidades modernas, os problemas de abastecimento de água e de esgotamento das águas servidas, pela própria importância sanitária e devido às deficiências ainda hoje encontradas em uma boa parte das cidade brasileiras, devem ser considerados prioritários para o planejamento.

Este sistema constitui-se no complemento necessário do sistema de abastecimento de água. Porém, as divergências são flagrantes e profundas, considerando que funcionam em sentido inverso, iniciando um onde o outro termina. A cada trecho da rede de distribuição de água deve corresponder o da rede coletora de água servida, ambas com exercício em marcha. Os fluxos, contudo, são opostos e de características diversas: o de água potável sob pressão, em conduto forçado e com vazão decrescente; o de esgoto, sob pressão atmosférica, em conduto livre e com vazão crescente.

O sistema de esgoto sanitário compreende, geralmente, a rede de canalizações e órgãos acessórios, órgãos complementares e dispositivos de tratamento dos esgotos, antes de seu lançamento no destino final. Assim, temse: Rede de Esgoto Sanitário; Ligação Predial; Poço de Visita; Estação Elevatória e Estação de Tratamento.

A Rede de Esgoto Sanitário é um conjunto de condutos ramificados, com traçado que lembra, no seu funcionamento, um sistema fluvial. $O$ desenvolvimento das tubulações é sempre feito dos pontos mais altos e trechos de menores dimensões até os pontos mais baixos, onde estão os trechos de maiores dimensões. Os condutos de pequenas dimensões afluem para condutos cada vez maiores, até atingirem os condutos principais do sistema de esgoto.

A Ligação Predial é um conjunto de elementos que têm por finalidade estabelecer a comunicação entre a instalação predial de esgotos de um edifício e o sistema público correspondente.

O Poço de Visita destina-se à concordância, inspeção, limpeza e desobstrução dos trechos dos coletores. Devem ser construídos em pontos críticos ou convenientes das instalações, tais como mudanças de direção ou declividade. 
A Estação Elevatória é indispensável em cidades ou áreas de pequena declividade e onde o ponto de lançamento se encontra em locais distantes. Em cidades médias e grandes, raramente os sistemas funcionam inteiramente por gravidade.

A Estação de Tratamento é responsável pela recuperação total ou parcial das águas servidas, por meio de processos que retiram as matérias orgânicas ou de outros tipos. Devido a problemática da poluição dos rios, esse é um elemento que tem papel cada vez mais importante no sistema.

A escolha dos materiais utilizados nas tubulações deve levar em consideração as condições locais (solo), as facilidades de obtenção e disponibilidade dos tubos e os custos dos mesmos. Normalmente, são utilizados tubos de seção circular, cujos materiais mais comuns são: cerâmica, concreto simples ou armado, ferro-fundido e PVC.

\subsection{5 - SISTEMA DE ENERGIA ELÉTRICA}

Para Mascaró (1989), o uso da energia elétrica, entre outros fatores, fez com que as cidades mudassem de tamanho, morfologia e função. Permitiu a verticalização das cidades ao propiciar a eletrificação dos sistemas de transporte vertical de pessoas, cargas e elevação de água.

Para se conseguir um completo fornecimento de energia elétrica é necessário um conjunto de elementos interligados, com a função de captar energia primária, convertê-la em elétrica, transportá-la até os centros consumidores e distribuí-la, onde é consumida por usuários residenciais, industriais, serviços públicos, dentre outros. O sistema de energia elétrica se subdivide em: Sistema de Geração; Sistema de Transmissão e Sistema de Distribuição.

O Sistema de Geração pode ser agrupado, de uma maneira geral, em sistemas convencionais (hidrelétricas, a vapor, motores diesel, termonucleares), sistemas não-convencionais (solares, eólicas, geotérmicas) e sistemas em desenvolvimento (pilhas de combustível, termiônicas). 
O Sistema de Transmissão geralmente é dividido em duas partes, transmissão através da zona rural e transmissão dentro do espaço urbano (subtransmissão). Apresenta-se, na maioria dos casos, interligado regional ou até mesmo nacionalmente entre si e entre os sistemas de geração de energia, possibilitando, assim, o aumento da confiabilidade de abastecimento em situações anormais ou de emergência. Os sistemas de transmissão são responsáveis por cerca de $80 \%$ das interrupções acidentais no fornecimento da energia elétrica, sendo assim a parte do fornecimento de energia mais vulnerável.

O Sistema de Distribuição é composto, basicamente, por: Redes de Distribuição; Sistema de Posteamento; e Ligações Prediais.

A Rede de Distribuição tem duas partes fundamentais: uma rede primária que alimenta os usuários através de uma rede secundária. Pode ser aérea ou subterrânea, dependendo principalmente da densidade populacional da região a ser atendida. A rede aérea, mais comum e mais econômica, utilizada no Brasil (geralmente composta por três ou quatro fios) possui o inconveniente de causar conflitos com a arborização urbana (curtos-circuitos por ocasião de ventos ou tempestades) além da falta de estética. Problemas também poderão ocorrer quando da utilização da rede subterrânea, pois poderá haver conflito com as raízes das árvores.

O Sistema de Posteamento, normalmente utilizado para sustentação da rede aérea, é de concreto tubular ou de madeira, empregando-se, em geral, postes de 9,0 m de comprimento para redes secundárias e de $11,0 \mathrm{~m}$ para as primárias, além dos elementos para iluminação pública.

As Ligações Prediais consistem, no conjunto de dispositivos que têm por finalidade estabelecer comunicação entre a rede de distribuição e a instalação elétrica dos prédios, sendo, geralmente, constituída de entrada da instalação consumidora (entre o poste e o medidor de consumo) e o ramal de serviço. 


\subsection{6 - SistemA DE ENERGIA A GÁS}

O gás natural possui grandes reservas mundiais, superiores até às de petróleo, e tem qualidade sempre uniforme. É uma fonte de energia econômica, confiável e versátil. A aplicação do gás natural proporciona maior segurança, produtos de melhor qualidade, abastecimento contínuo e, principalmente, respeito pela natureza e pelo meio ambiente. São benefícios que se transferem para o seu dia-a-dia, representando um ganho substancial de qualidade de vida, conforto e praticidade.

O fornecimento de energia a partir do gás combustível é bastante parecido, na morfologia, com o de energia elétrica, sendo composto, basicamente, por uma usina de produção ou jazidas de gás natural, com os respectivos sistemas de extração; instalações de armazenamento, compressoras, odorizadoras, misturadoras e filtradoras; estações reguladoras de pressão e rede de distribuição. As características dos elementos componentes do fornecimento de energia a gás combustível dependem do tipo de gás a ser distribuído e do tipo de usuário.

A rede de gás é sempre subterrânea e apresenta estruturas, materiais e diâmetros de tubulações similares aos da rede de água. Devido à sua periculosidade, sua localização é a mais isolada possível em relação às demais redes subterrâneas e às edificações.

\subsection{7 - SISTEMA DE COMUNICAÇÕES}

O sistema de comunicações é constituído, fundamentalmente, por dois tipos de rede: a rede telefônica e a rede de televisão a cabo. As conexões deste sistema são feitas por condutores metálicos, e, mais recentemente, de fibras óticas, cabos (terrestres ou submarinos) e satélites. As redes de infraestrutura que compõem este sistema (cabeamento e fios) seguem especificações similares do sistema energético. Já os satélites fazem parte da engenharia aeroespacial. 
Sem dúvida, este sistema é o que mais se desenvolve atualmente, a uma velocidade muito grande. A substituição dos deslocamentos humanos pela transferência de arquivos digitais levou à criação do termo superestrada da informação ou superinfovia. Por ela trafegam vídeos, músicas, serviços de diversos tipos e mensagens.

Segundo Toni (1995), a Era da Informação - expressão cunhada para caracterizar o aumento da importância dos novos meios de comunicação deve muito ao computador, à indústria de informática e aos satélites de comunicação.

\section{3 - AS REDES SEGUNDO SUA LOCALIZAÇÃO}

A desarticulação entre empresas de serviços públicos é grande e se traduz em uma séria desordem do subsolo urbano e efeitos estéticos e urbanísticos desagradáveis, acarretando maiores custos de implantação e operação e dificultando as necessárias renovações e ampliações próprias de cada rede. Essa desarticulação ocorre, principalmente, devido à falta de um cadastro geral, que contenha as localizações, precisas, de todas as redes e seus equipamentos complementares.

Mascaró (1987) assegura que uma das maneiras de se evitar problemas é localizar as redes a diferentes níveis e em diferentes faixas, segundo suas características. Os níveis usados para localizar as redes, que dão origem à classificação por localização das mesmas, são os seguintes: Nível Aéreo; Nível da Superfície do Terreno; Nível Subterrâneo.

\subsection{1 - Nível AÉREO}

Neste nível, são localizadas, normalmente, as redes de distribuição de energia elétrica, telefonia e TV a cabo. Há casos (e em muitos países essa é a norma) em que essas redes são subterrâneas. A localização subterrânea traz 
muitas vantagens, pois evita a exposição das redes aéreas às intempéries (ventos fortes e raios), a interferência com árvores, com veículos e até mesmo com pessoas. A escolha das posições relativas dessas redes, de suas alturas em relação à copa das árvores e à direção dos ventos dominantes merece considerações específicas para reduzir ao mínimo a interferência.

\subsection{2 - NÍVEL dA SUPERFÍCIE do TERRENO}

Este nível é ocupado pelos pavimentos do sistema viário, as calçadas para pedestres e as ciclovias (entre outras formas de vias de tráfegos), além das redes superficiais que compõem o sistema de drenagem pluvial (meiosfios, sarjetas, bocas-de-lobo, canais). É necessário ressaltar que este nível pode ser considerado o mais importante, pois a pavimentação é o mais caro dos elementos das redes que compõem os subsistemas de infra-estrutura urbana, representando cerca de $50 \%$ do custo total do conjunto e ocupando uma parcela importante do solo urbano.

O sistema viário e de drenagem das águas pluviais, uma vez implantados, são os que mais dificuldades apresentam para sua ampliação ou modificação, devido aos custos e às interferências que acarretam no meio urbano, razão pela qual suas boas ou más condições são imediatamente percebidas.

Este nível não interfere com os demais, mas sofre influência do nível subterrâneo, já que as reparações e ampliações das redes localizadas no subsolo são executadas com a quase inevitável destruição dos pavimentos (seja nas calçadas para pedestres ou nas vias para veículos).

\subsection{3 - NÍVEL SUBTERRÂNEO}

Neste nível localizam-se as redes profundas do sistema de drenagem pluvial, de água, de esgoto, de gás canalizado e, eventualmente, energia 
elétrica e comunicações, assim como de parte do sistema viário (metrô e passagens subterrâneas para pedestres). É o nível mais difícil de ser organizado devido às possibilidades de congestionamento e interferências recíprocas entre os diversos sistemas (ou suas partes) nele localizados. Além disso, a organização deste espaço exige articulação institucional, já que cada um dos sistemas que compõe a infra-estrutura urbana é, em geral, gerido por diferentes órgãos, de distintas instâncias do governo, que nem sempre atuam de forma coordenada.

Neste nível devem ser equacionadas, também, as interferências técnicas entre os diversos sistemas, como o de água e o de esgoto (possibilidade de contaminação da rede de água pelo vazamento de esgotos) e os de energia elétrica e gás canalizado (explosões ocasionadas por faíscas da rede elétrica na presença de vazamentos nas tubulações de gás).

Ficam evidentes os benefícios sócio-econômicos resultantes de uma boa organização dos três níveis de localização dos subsistemas que compõem a infra-estrutura urbana, por exemplo, por meio da fixação de faixas, horizontais e verticais, aéreas e subterrâneas, nas quais seriam localizadas as redes, devidamente compatibilizadas com a presença da arborização urbana.

\section{4 - CUSTOS DOS SISTEMAS DE INFRA-ESTRUTURA URBANA}

Conforme visto anteriormente, os sistemas que compõem a parte física da infra-estrutura urbana possuem os seguintes elementos básicos: Redes de Serviço; Ligações Domiciliares e Equipamentos Complementares.

As Redes de Serviço são compostas pela malha de tubulações, cabos, ou pavimentos, que se distribuem pela cidade, viabilizando os serviços. Os traçados urbanos e outros aspectos morfológicos das cidades influenciam fortemente em seus custos, razão pela qual os custos dos elementos dependem, em grande parte, dos urbanistas.

As Ligações Domiciliares são ramais que ligam as redes de serviços às instalações prediais. Seus custos vinculam-se intimamente com a tipologia 
adotada para as redes pelas empresas de serviços e pela tipologia de edifícios escolhida pelos usuários.

Os Equipamentos Complementares são partes individualizadas e importantes dos diferentes subsistemas. Tem-se, por exemplo, no abastecimento de água, a adução, a potabilização e a reservação; no de esgoto, os emissários e as plantas depuradoras, no de gás encanado, as fábricas de gás artificial ou os poços de gás natural, os gasodutos e a rede de armazenagem; no de abastecimento de energia elétrica e iluminação pública, as centrais, termo ou hidroelétricas, suas redes de transmissão e as estações para média tensão.

O custo de implantação desses elementos depende pouco das decisões dos urbanistas, a não ser quando trabalham na criação de uma cidade, pois exercem influência com a escolha de localizações que afetam os custos de transmissão, adução, emissão, entre outros, além da forma dos lotes.

Na Tabela 2.1 é indicada, para cada subsistema, a participação percentual de cada uma das redes, ligações e equipamentos complementares no custo de cada um, com base em dados dos Estados Unidos. Pode-se observar que as decisões de desenho urbano afetam totalmente as duas primeiras redes e, de forma parcial e variável, as restantes.

Tabela 2.1 - Participação média, em porcentagem, das diferentes partes nos custos totais dos subsistemas urbanos (Mascaró, 1989).

\begin{tabular}{lcccc}
\hline \multicolumn{1}{c}{ Sistema } & Rede & $\begin{array}{c}\text { Ligação } \\
\text { Domiciliar }\end{array}$ & $\begin{array}{c}\text { Equipamento } \\
\text { Complementar }\end{array}$ & Total \\
\hline Pavimento & 100,0 & - & - & 100,0 \\
Drenagem Pluviais & 100,0 & - & - & 100,0 \\
Abastecimento de Água & 15,5 & 25,5 & 59,0 & 100,0 \\
Esgoto Sanitário & 39,0 & 3,0 & 58,0 & 100,0 \\
Gás Encanado & 19,0 & 12,0 & 69,0 & 100,0 \\
Energia Elétrica & 20,5 & 15,0 & 64,5 & 100,0 \\
Iluminação Pública & 26,5 & - & 73,5 & 100,0 \\
\hline
\end{tabular}


Nota-se na Tabela 2.2 que a pavimentação e a drenagem são responsáveis por mais da metade do custo do sistema total. Nela é indicada a participação de cada uma das redes de infra-estrutura urbana no custo total de implantação das redes.

Tabela 2.2 - Participação, em porcentagem, de cada rede no custo total (Mascaró, 1989).

\begin{tabular}{lcc}
\hline \multicolumn{1}{c}{ REDE } & Área de baixa densidade & Área de alta densidade \\
\hline Pavimento & $42 \%$ & $44 \%$ \\
Drenagem Pluvial & $14 \%$ & $16 \%$ \\
Abastecimento de Água & $4 \%$ & $3 \%$ \\
Esgoto Sanitário & $17 \%$ & $20 \%$ \\
Gás Encanado & $9 \%$ & $9 \%$ \\
Energia Elétrica & $13 \%$ & $7 \%$ \\
Iluminação Pública & $1 \%$ & $1 \%$ \\
\hline
\end{tabular}

\section{5 - GERÊNCIA DE INFRA-ESTRUTURA URBANA}

A gerência de infra-estrutura urbana é um processo de coordenação, avaliação sistemática e manutenção efetiva da infra-estrutura relacionada com os serviços básicos (ZHANG et al., 1994).

Um sistema de gerência da infra-estrutura une as atividades necessárias para as ações de planejamento, projeto, construção, manutenção, reabilitação e avaliação através de uma série de procedimentos de análises racionais e bem ordenados.

Uma manutenção efetiva do pavimento e das outras infra-estruturas na área urbana pode aumentar muito a vida em serviço dessas infra-estruturas e reduzir o custo para os usuários. Porém, o que se tem observado, na maioria das cidades, é a ausência de trabalho integrado entre as diversas áreas do serviço público municipal que interferem no espaço da via pública.

Em outras palavras, com o crescimento das cidades são necessárias novas aberturas de trincheiras para a ampliação e manutenção das instalações 
existentes, sendo que os remendos, muitas vezes executados de forma inadequada, geralmente resultam na diminuição da qualidade de rolamento e da integridade estrutural dos pavimentos.

A coordenação das atividades de manutenção do pavimento com as atividades de manutenção da infra-estrutura pública urbana (água, esgoto, energia elétrica, telefone, gás etc.), apesar das dificuldades, é indispensável quando se deseja implantar um sistema de gerência para as atividades de manutenção da infra-estrutura urbana.

É necessário, portanto, o desenvolvimento de um sistema de manutenção da infra-estrutura pública urbana capaz de proteger os pavimentos urbanos e determinar os direitos e responsabilidades de cada subsistema de infra-estrutura urbana (Figura 2.4).

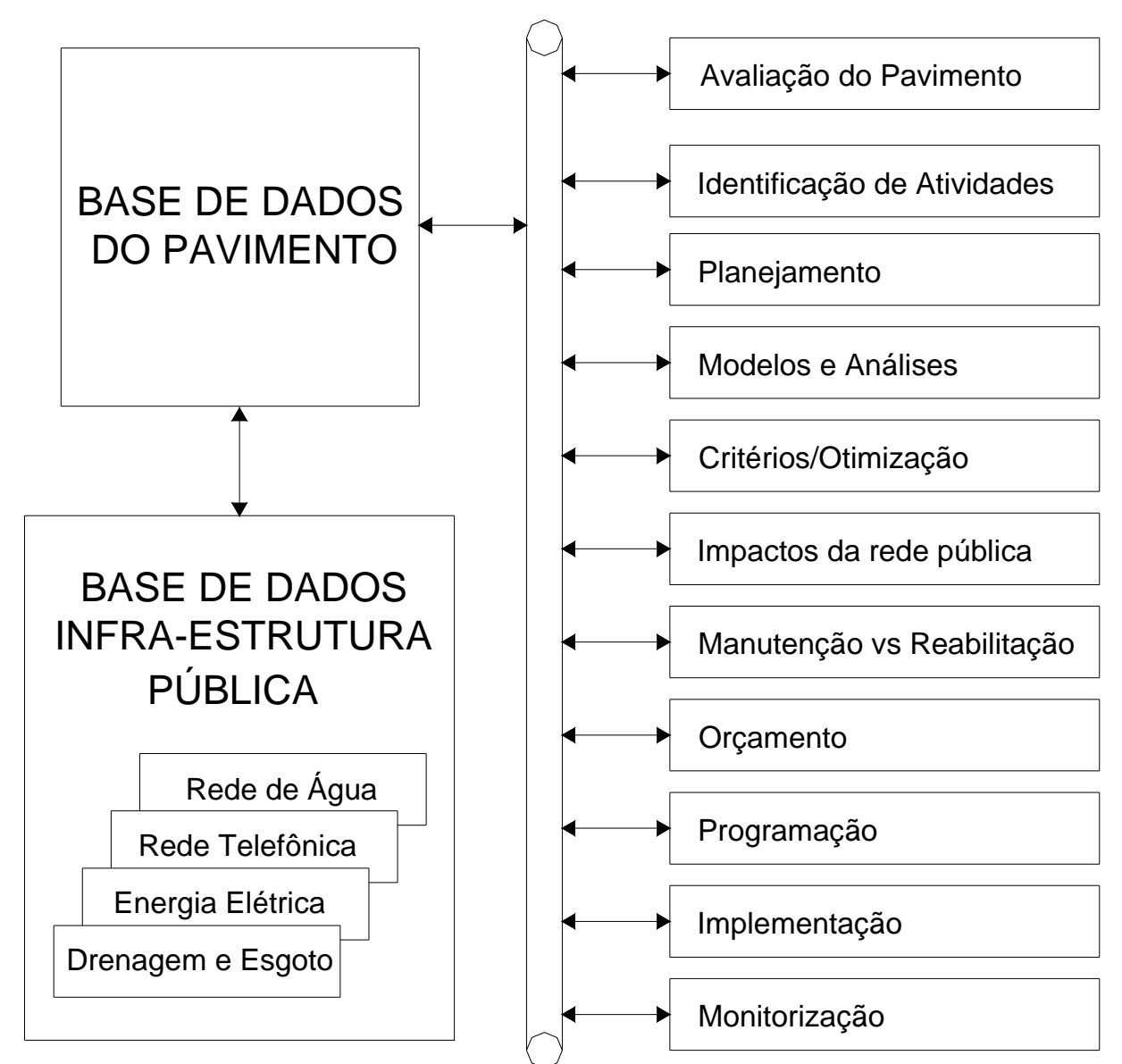

Figura 2.4 - Plataforma para um sistema de manutenção da infra-estrutura urbana (adaptada de AL-SWAILMI, 1994). 
Tal sistema global de manutenção de infra-estrutura pública deve permitir a coordenação e comunicação ao invés da situação tradicional, caracterizada pelo trabalho fragmentado e independente dos diferentes subsistemas da infra-estrutura pública.

Os órgãos que administram os serviços de água, esgoto, gás, energia elétrica, telefone e águas pluviais, para considerar apenas os que dizem respeito às cidades brasileiras, utilizam a via pública para suas instalações. $\mathrm{Na}$ maioria das cidades, essa utilização tem sido desordenada e sem um critério geral que possa evitar os inconvenientes da interferência de um sistema no outro, conforme representado na Figura 2.5 (MISAWA et al., 1975).

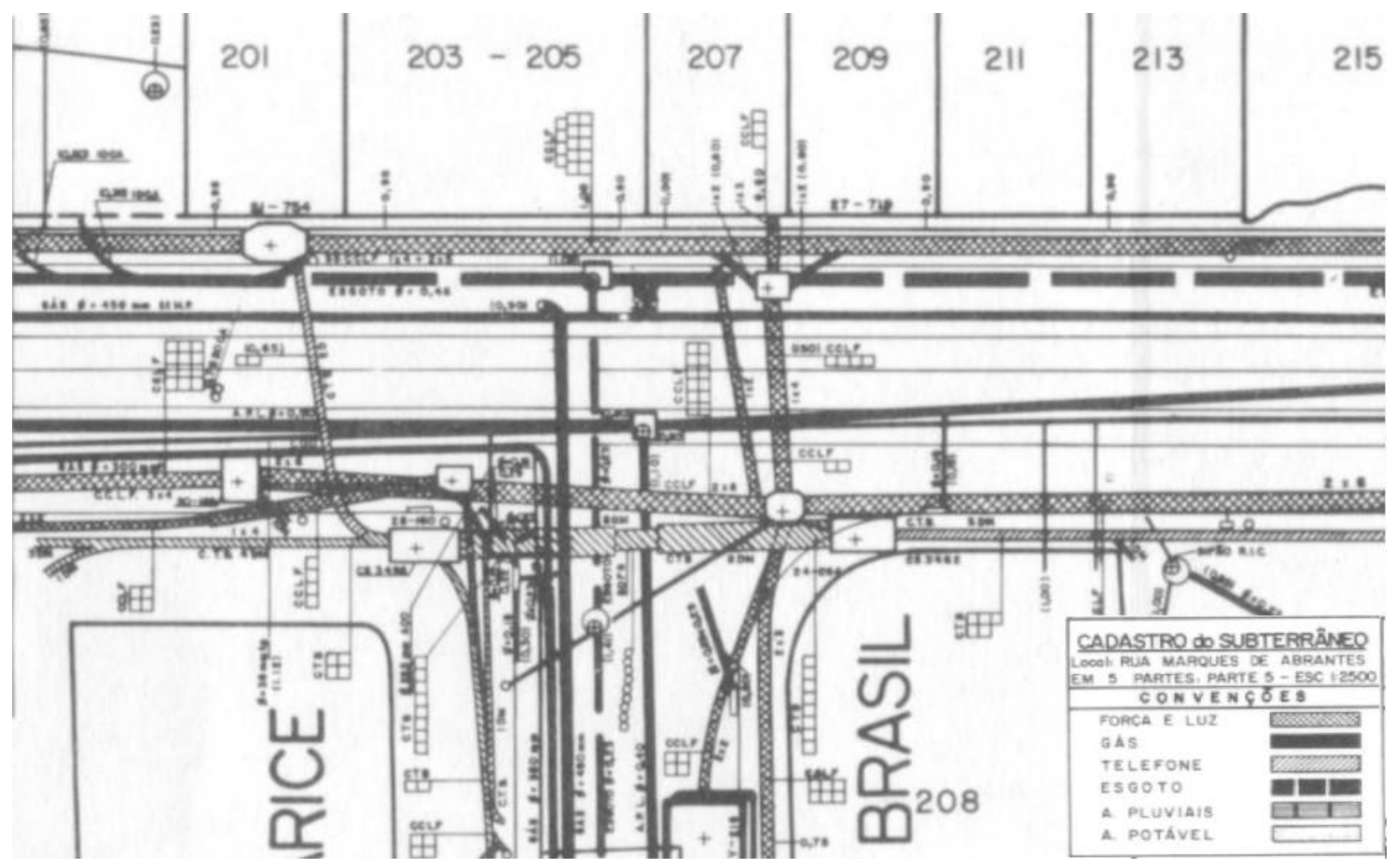

Figura 2.5 - Exemplo de utilização desordenada do subleito de uma via urbana (MISAWA et al., 1975).

São muitos os casos em que o primeiro serviço público a se instalar na via quase impede o aproveitamento da mesma pelos demais serviços. Esta situação caótica acaba por prejudicar todos os órgãos interessados e, principalmente, os próprios usuários dos serviços. 
Na cidade de São Paulo, várias tentativas já foram efetuadas, como a criação do Departamento de Controle de Uso das Vias Públicas (CONVIAS), visando regulamentar a questão mediante adoção de normas rígidas para construção de dutos, sob o passeio e pistas. As dificuldades para se estabelecer um acordo entre os vários órgãos interessados encontram-se no fato de os diversos sistemas já estarem em funcionamento.

Segundo Misawa (1975), a maioria dos centros urbanos necessita de um órgão coordenador dos serviços de utilidade pública. A esse órgão, com representação de todos os interessados, competiria a adoção de normas de utilização das vias, além de regular, de modo conjunto, a expansão dos vários serviços públicos.

Com o planejamento global da expansão e a melhoria de todos os serviços públicos, seria evitado o esburacar constante de uma via, ora pelo serviço de água ora pelos demais serviços.

Essa coordenação geral reuniria esforços e preservaria, em condições tecnicamente recomendáveis, a atuação de todos os órgãos, com a conseqüente melhoria dos serviços, de um modo geral, e redução dos gastos operacionais em benefício da coletividade. 


\section{3 - INTERFERÊNCIAS DE INFRA-ESTRUTURA URBANA}

\section{1 - INTRODUÇÃO}

No subleito de uma via urbana quase sempre se encontram redes de água potável e de esgoto. Dependendo da demanda, geometria da via e outras interferências, essas redes podem ser duplas, uma de cada lado da via. Além disso, podem ocorrer, também, redes de águas pluviais. Esses tipos de canalizações sempre são acompanhadas de acessórios, tais como registros e poços de inspeção ou visita. A partir da privatização de vários serviços, ocorrida na década de 90, as concessionárias de gás, energia elétrica, telefone e petróleo aumentaram as interferências no subleito das vias.

O ideal é que essas redes sejam construídas antes que se pavimente a via. Contudo, o que se observa é um verdadeiro ataque ao pavimento após a sua execução (Figura 3.1) e, por melhor que sejam executados os remendos, sempre causam desconforto, aumentam as cargas dinâmicas e tornam-se pontos frágeis e preferenciais para a infiltração de água.

Uma solução para o problema seria passar todas as redes sob a calçada. Infelizmente, as condições observadas em nossas cidades são desfavoráveis. Por exemplo, na Grande São Paulo os passeios variam de 1,50 a 2,00 metros de largura, enquanto seriam necessários pelo menos 3 metros de cada lado da via para a implantação dos serviços das concessionárias. 
Além disso, construtivamente é difícil devido à existência de postes de energia elétrica e de sinalização, árvores etc.

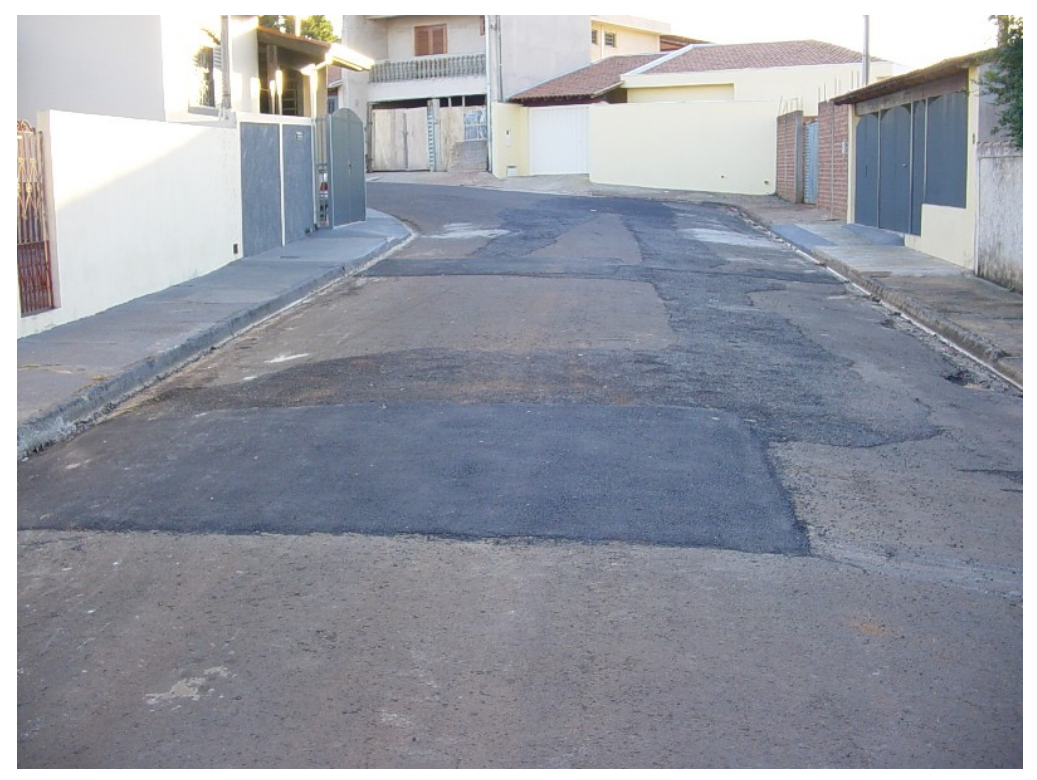

Figura 3.1 - Intervenções sucessivas no pavimento, relacionadas às infra-estruturas urbanas.

Porém, nos novos loteamentos apesar de tais dificuldades não existirem, ainda assim, os problemas também se manifestam devido a planejamentos deficientes e legislações ineficazes. Estes problemas já foram resolvidos em países europeus, como Portugal, que tem área territorial reduzida e cidades muito antigas, enquanto no Brasil, país com dimensões continentais e processo de urbanização recente, insiste-se em perpetuar o problema.

\section{2 - AS FASES DA INTERFERÊNCIA DE INFRA-ESTRUTURA URBANA}

Em qualquer serviço executado nas vias públicas, o órgão executor deve garantir a segurança dos pedestres, trabalhadores e veículos. Para atingir tal objetivo são necessários espírito de compreensão e cooperação entre os órgãos executores, trabalhadores e usuários de vias públicas, além de desvio do trânsito, se necessário, e principalmente o uso de sinalização adequada.

Para a construção de condutos, pode-se considerar as seguintes fases: 
- sinalização

- remoção da pavimentação;

- abertura da vala;

- esgotamento;

- escoramento;

- assentamento;

- preenchimento da vala;

- reposição de pavimentação.

\subsection{1 - SINALIZAÇÃO}

As obras e serviços em vias públicas devem ser executados com indispensável cuidado de boa sinalização, quer durante o dia, quer durante a noite, e de acordo com os elementos de sinalização diurna e noturna, recomendados e descritos nas normas de sinalização de obras em vias públicas.

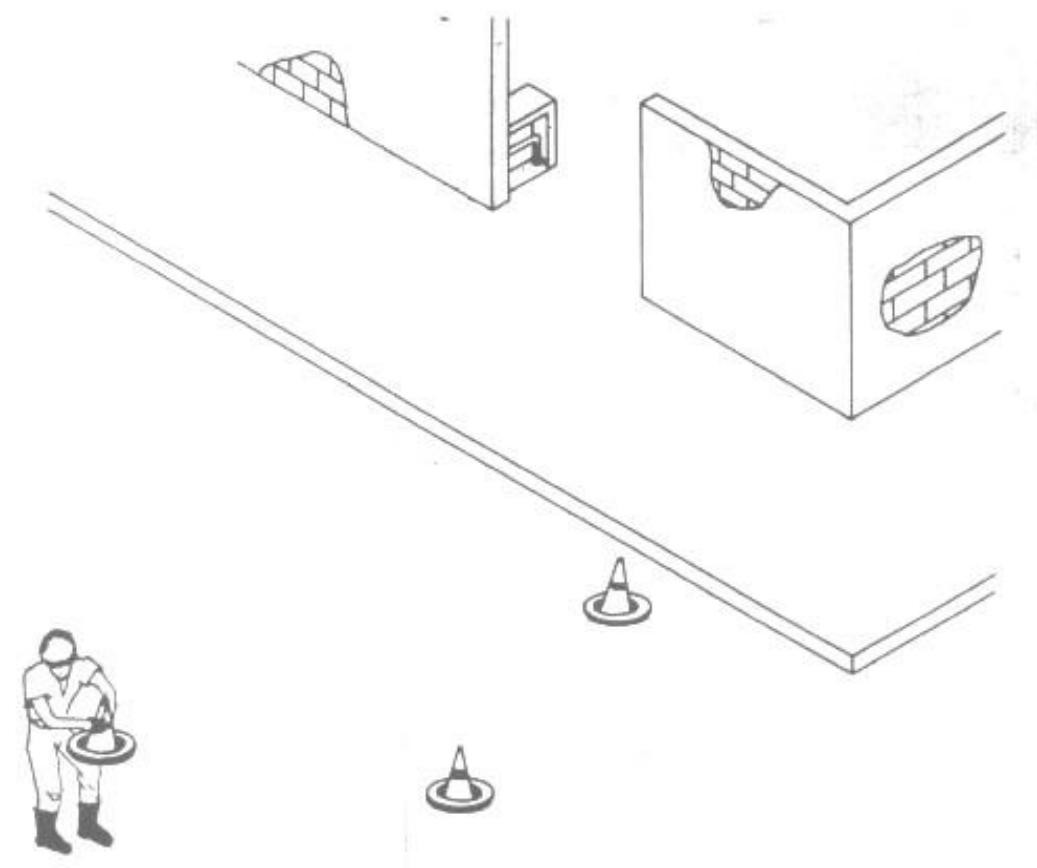

Figura 3.2 - Execução de sinalização de segurança (ABES, 1978). 
Os sinais de trânsito podem ser classificados em três classes principais:

- Sinais de Advertência: cuja finalidade é avisar aos motoristas e pedestres sobre a existência de algum perigo na rua (por exemplo: "Homens Trabalhando", "Obras a 50m");

- Sinais de Regulamentação: têm por objetivo informar aos motoristas e pedestres sobre proibições (por exemplo: "Trânsito Impedido: Obras");

- Sinais de Indicação: têm o objetivo de fornecer informações úteis aos motoristas e pedestres (por exemplo: "Direção a Seguir", "Sentido Obrigatório", "Pedestre, Use a Passarela").

A sinalização noturna é feita com os mesmos sinais usados na sinalização diurna, reunindo ainda as sinalizações refletivas ou luminosas.

Os elementos usados são os seguintes:

- tabuleta indicativa de homens trabalhando (sinal de advertência): é usado como medida de segurança quando não há necessidade de interromper o trânsito (Figura 3.3A);

- cavalete: é usado no fechamento parcial ou total da rua (Figura 3.3B);

- cone de sinalização: os cones de borracha são utilizados para marcação das faixas interditadas ao tráfego (Figura 3.3C).

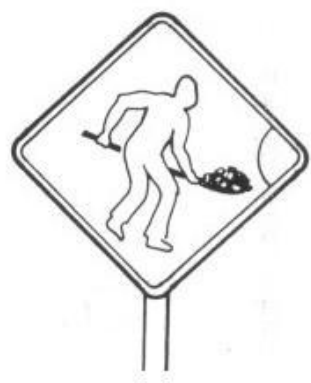

A

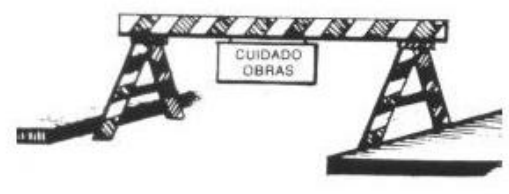

B

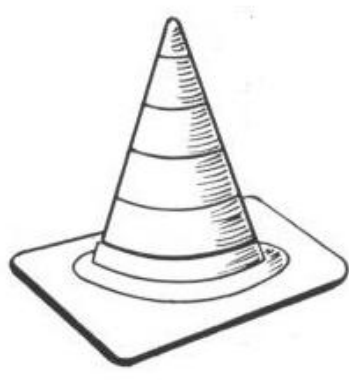

C

Figura 3.3 - Sinalizações utilizadas nas obras em vias públicas urbanas (ABES, 1978). 


\subsection{2 - REMOÇÃO DA PAVIMENTAÇÃO}

Alguns cuidados devem ser tomados antes do início dos trabalhos, como é o caso de se verificar o direcionamento das águas da superfície do pavimento, procurando-se evitar o escoamento para o interior das valas.

A área de trabalho deve ser previamente limpa, devendo-se retirar, quando possível, ou escorar solidamente, árvores, rochas, equipamentos, materiais, muros, edificações vizinhas e todas estruturas que possam ser afetadas. As concessionárias públicas devem ser contatadas para rastrear redes existentes nos locais a serem escavados, desligando-as quando oferecerem risco.

Primeiramente, deve ser feita a marcação dos bordos da vala, por meio de riscos no chão ou linhas de demarcação.

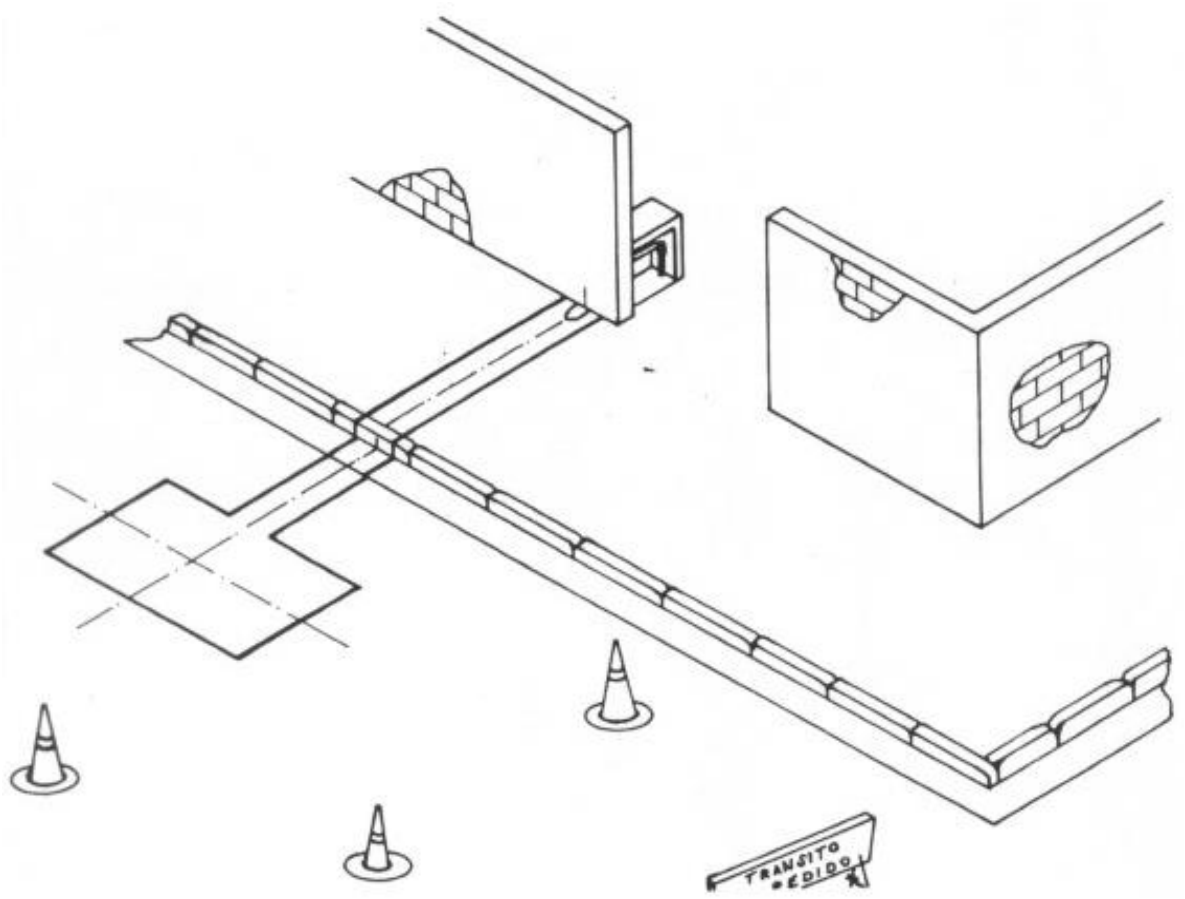

Figura 3.4 - Marcação de vala para ligação de água (ABES, 1978). 
Posteriormente, executa-se o corte do pavimento dentro da área determinada, removendo-se pequenas placas. A largura da faixa de pavimentação a ser removida ao longo da vala deve ser a mínima necessária, de acordo com o tipo da pavimentação. No asfalto, a largura deve ser a largura da vala mais $30 \mathrm{~cm}$; em passeio, a largura da vala mais $20 \mathrm{~cm}$. A pavimentação asfáltica deve ser removida, mecanicamente, através de rompedores pneumáticos ou outro equipamento apropriado. Já os passeios, geralmente de concreto, podem ser removidos mecânica ou manualmente.

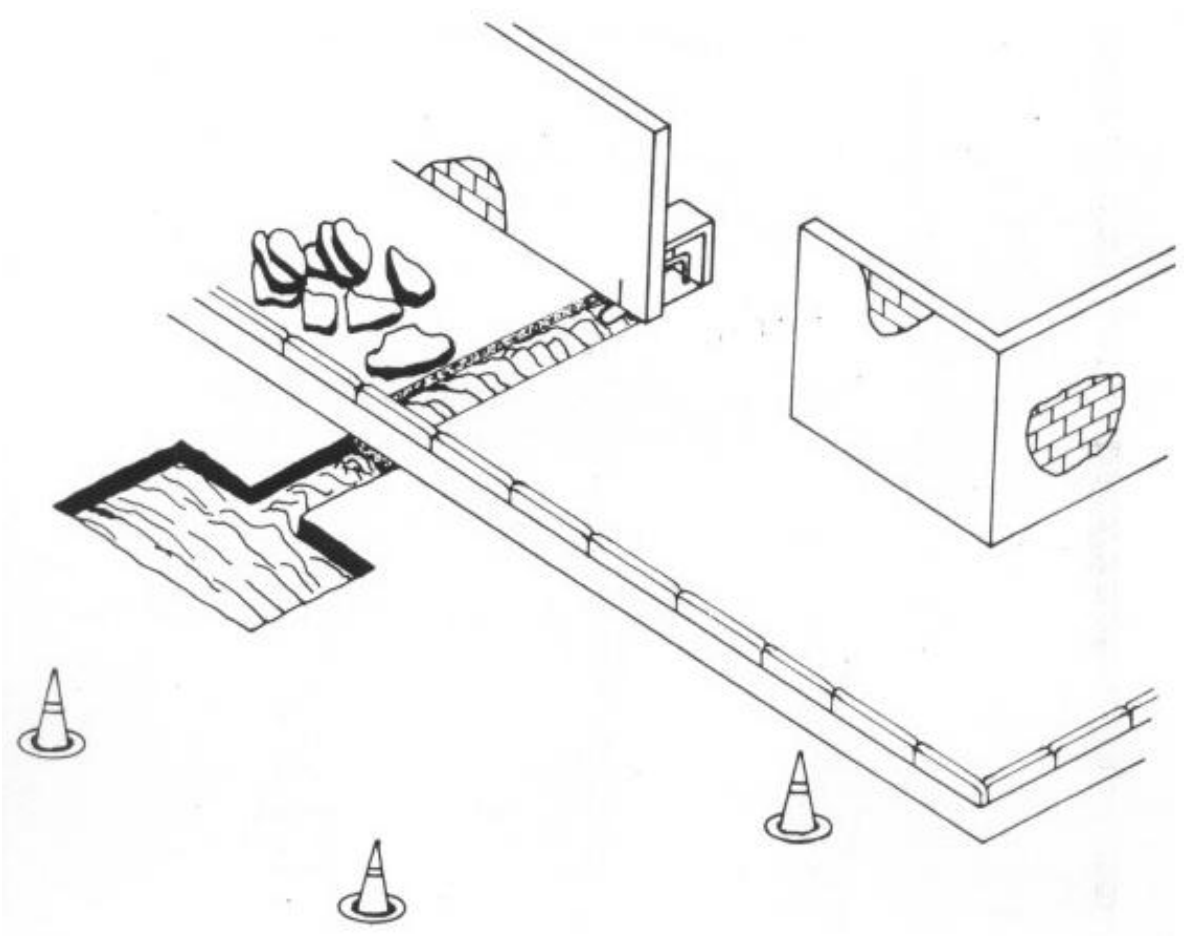

Figura 3.5 - Rompimento e remoção de pavimento (ABES, 1978).

\subsection{3 - ABERTURA DE VALAS}

Para início das escavações devem ser escolhidos métodos e processos de execução, conforme NBR 12266/92, tendo em vista obter o máximo grau de segurança. 
A abertura de valas não é uma tarefa simples, pois, normalmente, a instalação da canalização projetada ocorre em ruas que já possuem calçamento, galerias de águas pluviais, redes de água potável, gás, cabos telefônicos, postes, árvores etc. As valas são cortes a céu aberto e assim permanecem temporariamente.

$\mathrm{Na}$ abertura de valas, os materiais mais diversos são encontrados (argila, areia, silte, piçarra, rocha etc), dessa forma dois processos podem ser utilizados na abertura: o processo mecânico e o processo manual, cuja escolha é, geralmente, em função do tipo de solo e da profundidade.Em alguns casos é necessário escoramento para proteção das paredes laterais contra possíveis desmoronamentos. Somente em casos particulares ou quando as condições do solo permitirem, os taludes poderão ser inclinados.

Os materiais retirados das escavações devem ser depositados a uma distância superior à metade da profundidade, medida a partir da borda do talude. As escavações com mais de 1,25 m de profundidade devem dispor de escadas próxima ao posto de trabalho, a fim de permitir, em caso de emergência, a saída rápida dos trabalhadores.

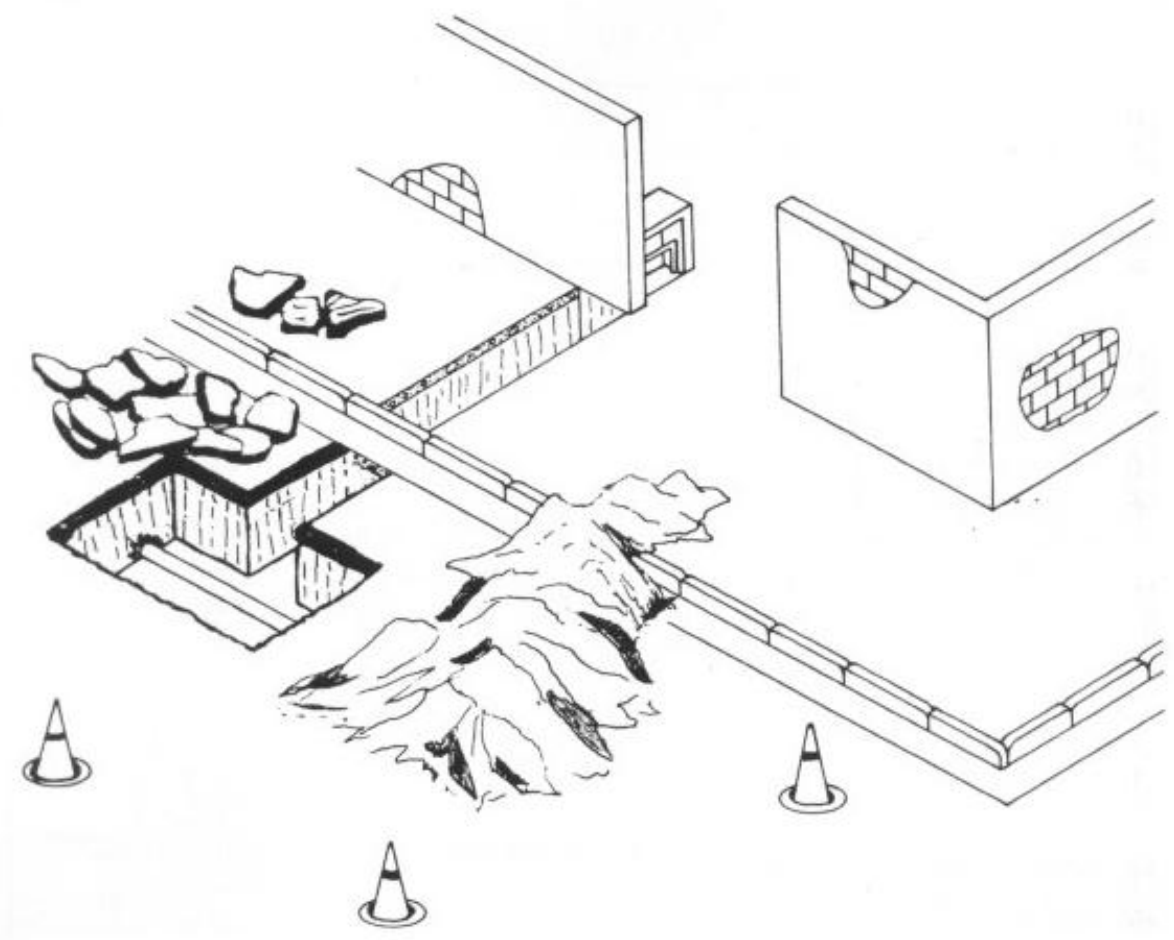

Figura 3.6 - Abertura de vala (ABES, 1978). 


\subsection{4-ESGOTAMENTO}

A água encontrada em valas pode ser conseqüência de chuva, vazamento de outras canalizações e lençóis ou minas de água.

O primeiro caso não apresenta problema, pois uma vez esgotada deixará o terreno seco novamente. Em quantidades pequenas o esgotamento com baldes é muito utilizado.

Os vazamentos são mais complexos, pois a tubulação vazando poderá ser, como normalmente acontece, uma galeria de águas pluviais antiga ou uma tubulação de água ou esgoto com ligações partidas. Quando estas tubulações encontram-se fora da vala, torna-se mais complicada a solução do problema, devido a dificuldade de se localizar o vazamento.

O terceiro caso é, sem dúvida, o que maiores complicações apresenta, pois há que se drenar a vala. A preocupação é localizar pontos mais baixo do "greide" projetado, para onde a água possa correr e acumular, sendo então retirada por meio de bombas (Figura 3.7).

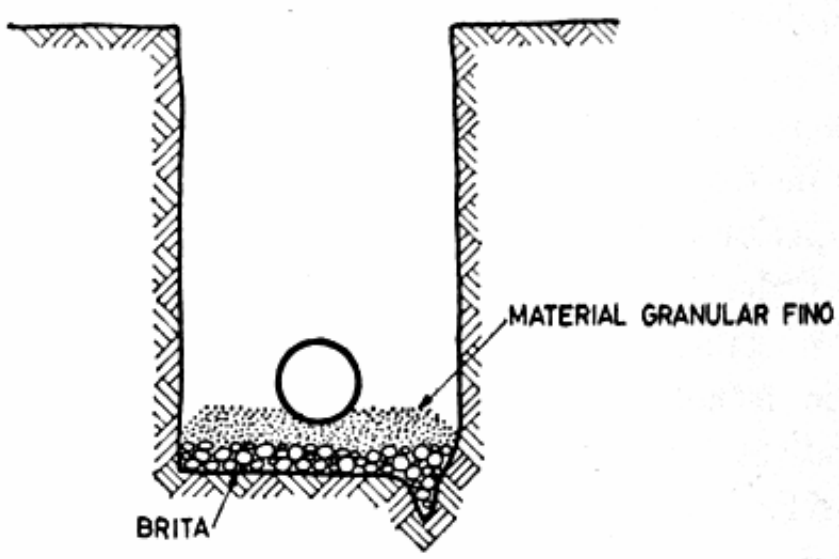

Figura 3.7 - Esgotamento: lastro de brita e canaletas (Nina, 1966).

Sempre que houver esgotamento, deve-se atentar para um fator importantíssimo, que é o solapamento das bases das valas, com o posterior desmoronamento dos taludes. Esta precaução é maior quando a vala estiver 
próxima a muros ou fundações de prédios e posteação. Neste caso, adota-se medida de precaução que é o escoramento.

\subsection{5-ESCORAMENTO}

Escorar é todo e qualquer processo que se destina a manter alguma coisa na posição desejada, quando esta não se pode manter sozinha pelo tempo necessário.

É importante porque age de duas maneiras: tem o fator físico da segurança e também o aspecto psicológico, pois em valas profundas, mesmo em terreno consistente, tal medida produz a sensação de segurança.

Em terrenos firmes pode-se usar um dispositivo como o da Figura 3.8, que protege os homens durante o assentamento dos tubos. A escavação é realizada mecanicamente, não havendo pois necessidade de proteção ao elemento humano durante a escavação.

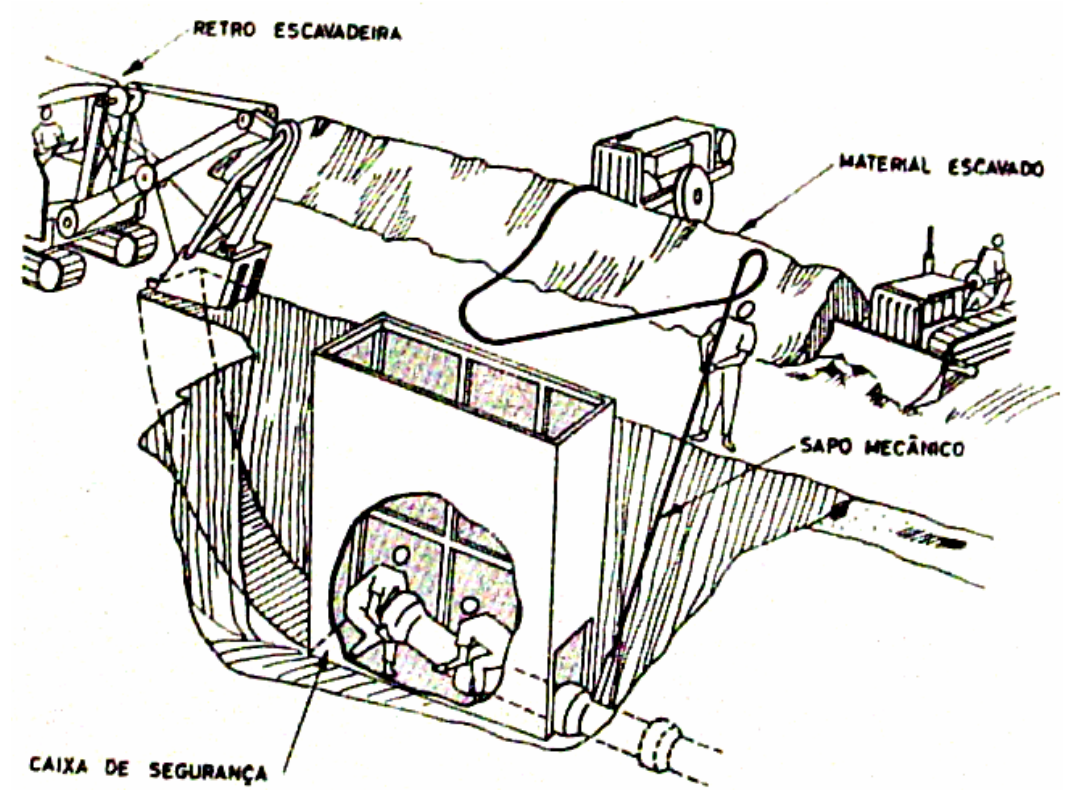

Figura 3.8 - Caixa de segurança (Nina, 1966). 


\subsection{6 - INSTALAÇÃO}

As tubulações devem ser instaladas sobre bases firmes, para evitar que os tubos se desloquem, prejudicando suas juntas e colocando-os sob riscos de quebra. As valas devem ter seu fundo regularizado e apiloado manualmente, recomendando-se colocar uma camada de $15 \mathrm{~cm}$ de areia grossa, formando uma fundação conformada para adaptar-se à parte inferior do tubo, numa largura igual ao seu diâmetro.

\subsection{7 - FECHAMENTO DAS VALAS}

A execução do reaterro é um fator importante, não só por influenciar diretamente na qualidade de reposição do calçamento mas, principalmente, pela influência que exercerá sobre as cargas verticais que atuam sobre as tubulações.

O reaterro deve ser compactado, entendendo-se por compactação de um solo o processo, manual ou mecânico, que visa reduzir o volume de seus vazios e aumentar, em decorrência, sua densidade. Com isso a capacidade de suporte dos solos também é acrescida.

As valas devem ser aterradas com cuidado, para não estragar os tubos e para que o solo não afunde com o passar do tempo. Devem ser utilizados solos com teor de umidade em torno da umidade ótima de compactação, compactados com equipamento adequado ao tipo e dimensões da vala. Durante o reaterro, caso ocorram chuvas, as camadas atingidas devem ser removidas. No caso de ocorrência de solo mole no fundo da vala ou de lençol d'água aflorante, deve-se evitar a saturação das camadas do reaterro mediante execução de drenos.

$\mathrm{Na}$ operação de fechamento deve-se utilizar solo com características iguais ou melhores que as do solo retirado da vala. O reaterro deve ser realizado em camadas. As primeiras camadas devem ser de $10 \mathrm{~cm}$, até que 
essas atinjam $10 \mathrm{~cm}$ acima do tubo. Deve-se respeitar o valor máximo de $20 \mathrm{~cm}$ de espessura de material solto (Figura 3.9).

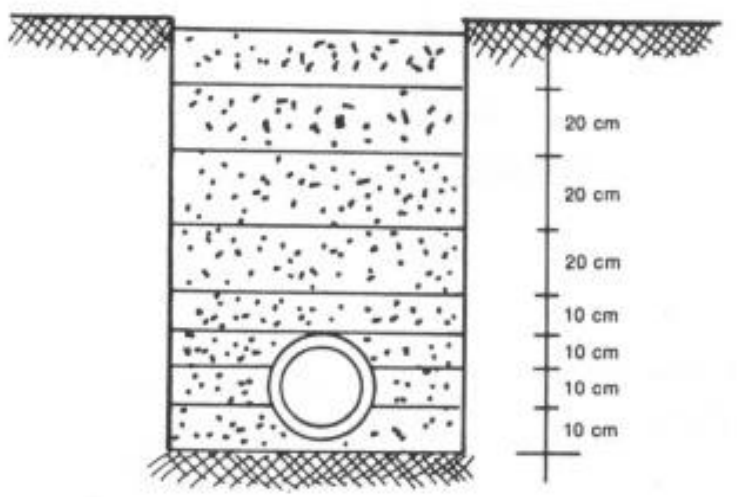

Figura 3.9 - Reaterro de vala (ABES, 1978).

\subsection{8 - RECONSTRUÇÃO DO PAVIMENTO}

A reposição da pavimentação em vias públicas deve objetivar o restabelecimento do pavimento com características estruturais iguais ou superiores às do pavimento original, obedecendo às recomendações e exigências municipais. A superfície acabada deve estar nivelada com o pavimento original.

Grande parte dos problemas dos pavimentos urbanos estão diretamente associados à má qualidade dos serviços de recomposição de valas abertas para instalação ou reparo de redes de infra-estrutura urbana. Portanto, é de grande importância o controle de qualidade dos remendos, que é considerado o método de reparo mais utilizado na manutenção de rodovias e ruas.

Para os usuários, os buracos devem ser reparados de imediato, pois comprometem a segurança e o conforto e aumentam os custos operacionais. Além disso, permitem a entrada de água, que provoca o enfraquecimento da estrutura e acelera a deterioração. 


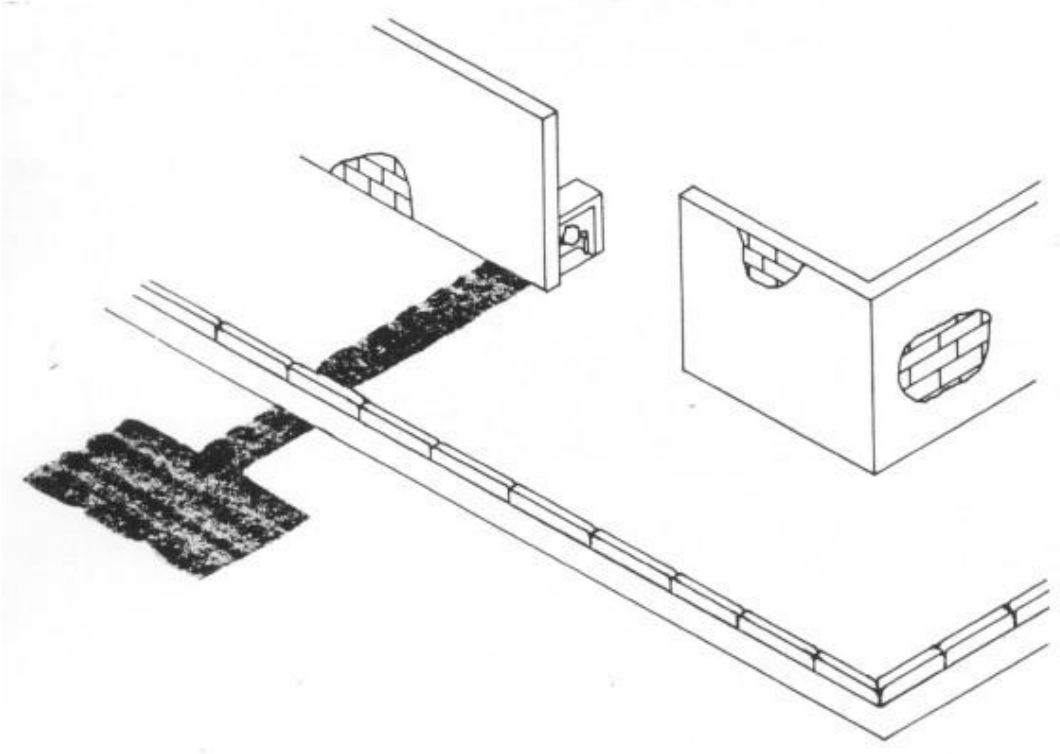

Figura 3.10 - Reposição do pavimento (ABES, 1978).

A decisão sobre o momento da execução dos remendos e, principalmente, a forma de execução são influenciadas por muitos fatores, dentre eles:

- volume de tráfego;

- tempo até a reabilitação ou recapeamento programados;

- disponibilidade de pessoal, equipamentos e materiais.

Em qualquer operação de remendo, os elementos principais são a seleção de materiais e os procedimentos do reparo. Quanto ao tipo de material, podem ser usadas misturas asfálticas usinadas a quente (CBUQ), no caso de reparos permanentes, ou pré-misturados a frio (PMF), no caso de reparos emergenciais, executados sob condições climáticas desfavoráveis.

\section{3 - EXECUÇÃO DE REMENDOS}

Dentre os vários métodos de reparo, os mais tradicionais na maioria das cidades brasileiras são os remendos simples (ou "tapa-buraco"), compactado e permanente. 


\subsection{1 - REMENDO SIMPLES}

É o método de reparo mais utilizado, não só no Brasil. Consiste do simples lançamento da mistura asfáltica, sem cuidados prévios (limpeza e drenagem) ou posteriores (compactação). Embora não represente uma técnica adequada, sua elevada produtividade o torna muito popular entre as equipes de manutenção e reabilitação de pavimentos. Tem o nome popular de "tapaburaco".

\subsection{2 - REMENDO COMPACTADO}

Representa uma transformação do método do remendo simples, capaz de produzir um remendo de melhor qualidade. Consiste no lançamento de material asfáltico sobre uma superfície limpa e seca, seguido de uma compactação executada com os pneus do próprio caminhão transportador da mistura. É necessário deixar uma pequena saliência, da ordem de $3 \mathrm{~m} 5 \mathrm{~m}$, de modo a permitir que o remendo fique nivelado com o pavimento circunvizinho após a compactação adicional proporcionada pelo tráfego.

\subsection{3 - REMENDO PERMANENTE}

Neste método de reparo deve-se remover a água e a sujeira. Se a presença de água for a causa do defeito, deve ser efetuada a instalação de drenagem. O procedimento inicia-se com o corte em forma de retângulo da área a ser remendada. Esta área deve ser delimitada, em torno de $20 \mathrm{~cm}$ além das extremidades do buraco, e sua profundidade deve atingir uma camada com material consistente.

Aplica-se ligante asfáltico nas faces verticais e no fundo da escavação, neste caso para impermeabilizar, caso o material seja granular. Deve-se lançar 
a mistura asfáltica contra as paredes verticais dos cortes, para evitar segregação, e seguir esparramando da extremidade para o centro.

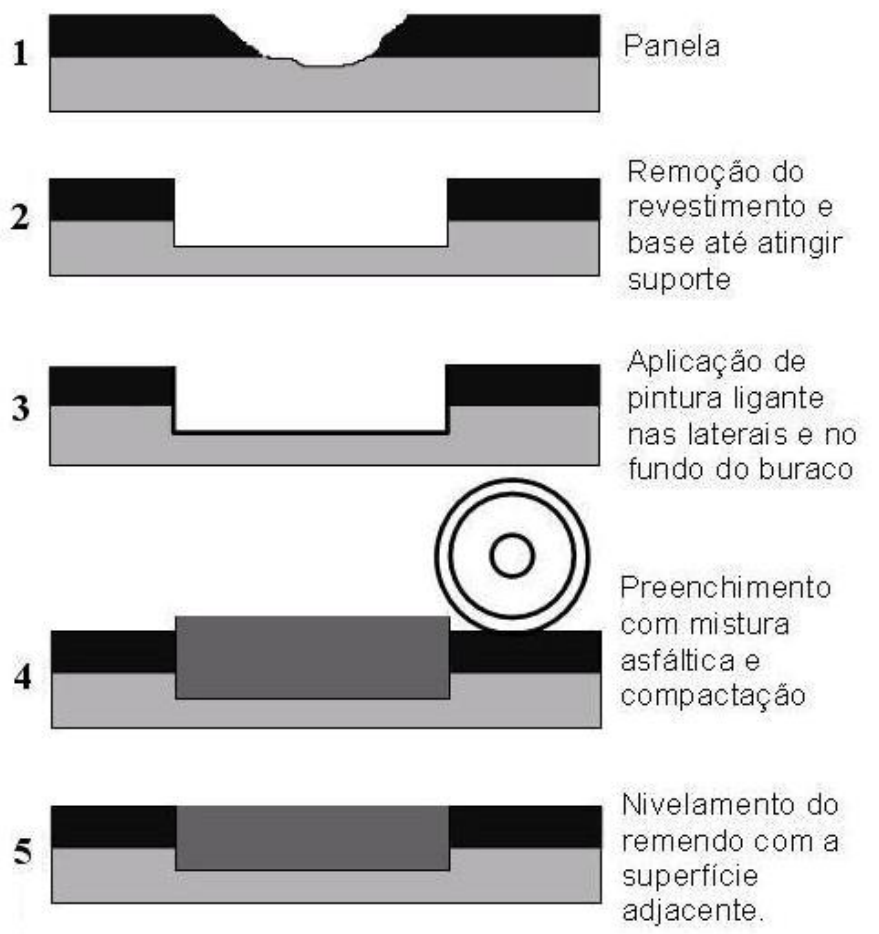

Figura 3.11 - Procedimentos para execução de um remendo permanente (SHRP, 1993a).

Compacta-se com equipamento adequado, menor do que a área do remendo (rolo compactador pequeno ou placa vibratória). Quando a profundidade for superior a $15 \mathrm{~cm}$, a compactação deve ser realizada em camadas, devendo resultar numa superfície perfeitamente nivelada com o pavimento adjacente.

\subsection{4 - AVALIAÇÃO DOS REMENDOS}

A diferença de desempenho entre o tradicional remendo simples e o remendo compactado é muito maior do que o custo adicional, em razão do tempo gasto durante a compactação (geralmente, 1 a 2 minutos). 
O remendo permanente apresenta desvantagem quanto aos custos iniciais envolvidos, pois exige mais trabalhadores e equipamentos e acaba apresentando uma menor produtividade. Se não houver uma compactação adequada, um remendo com mistura asfáltica usinada a quente pode durar tão pouco quanto uma mistura preparada a frio.

O principal problema é que os remendos temporários, na grande maioria das vezes, constituem o único procedimento de reparo executado. Um trabalho desenvolvido pelo Corpo de Engenheiros do Exército dos Estados Unidos em 1981, citado por Evans et al. (1993), comparou os custos de vários métodos de execução de remendos. De forma resumida o estudo concluiu que o procedimento para remendo permanente apresenta um custo por tonelada da ordem de três vezes menor que o custo do procedimento para remendo temporário, levando-se em consideração a relação custo benefício.

Porém, nem sempre é possível a execução de remendos com tempo quente e seco. Freqüentemente, as condições climáticas obrigam a execução de remendos temporários, que têm a finalidade de evitar um dano maior ao pavimento. Nesses casos, deve-se redobrar os cuidados e não se esquecer de que os reparos executados sob condições climáticas desfavoráveis são apenas temporários e apresentam elevado custo por tonelada, em razão de terem vida em serviço muito curta.

\subsection{5 - DESEMPENHO DOS REMENDOS}

Segundo Bertollo (1997), para determinar o tipo de remendo a se executar, as prefeituras deveriam comparar seus desempenhos por um período mínimo de um ano, sendo que a monitorização consiste basicamente em verificar se os remendos executados apresentaram ou não problemas. Os resultados podem ser representados em um gráfico equivalente ao da Figura 3.12, que permite a visualização do tipo de remendo com melhor desempenho (maior área sob a curva). 
Portanto, com a determinação dos custos e a avaliação do desempenho, segundo os procedimentos apresentados, as prefeituras municipais têm condições de confrontar as diferentes formas de execução dos remendos e, assim, quantificar o custo adicional de um "tapa-buraco" em relação a um remendo bem executado.

Curva de Desempenho dos Remendos

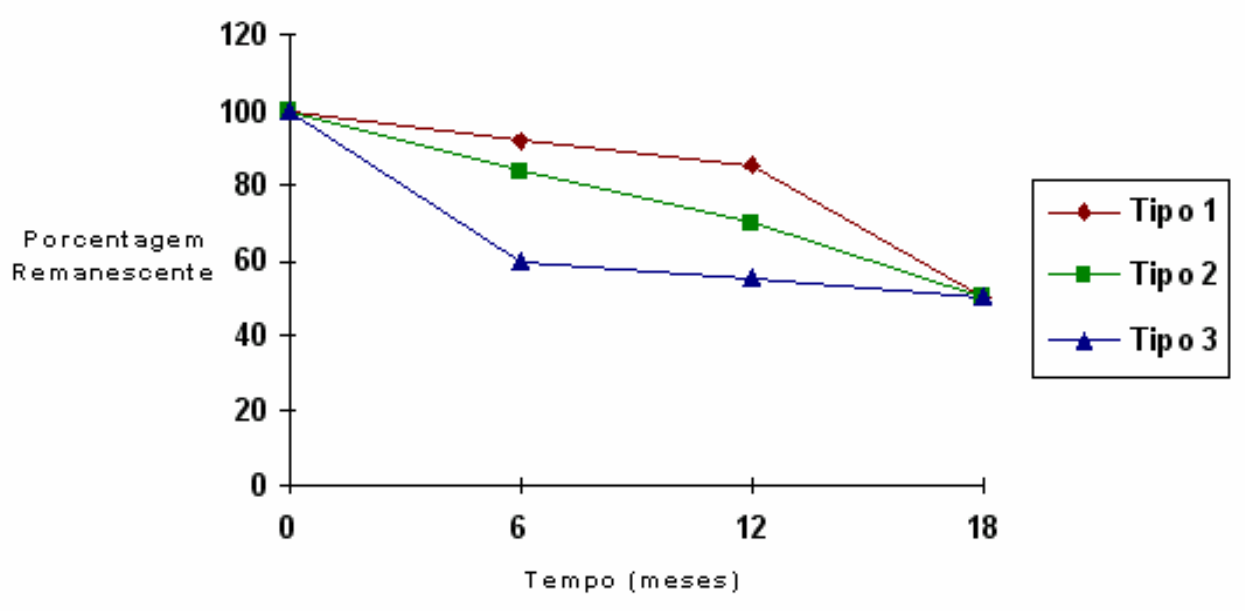

Figura 3.12 - Exemplo de gráfico para comparação do desempenho de diferentes formas de deterioração (SHRP, 1993a).

\section{4 - DEFEITOS DEVIDO À EXECUÇÃO INADEQUADA}

A abertura e o fechamento de valas por concessionárias de serviços de infra-estrutura urbanas, particularmente de água e esgoto, segundo Augusto Jr., Giampaglia e Cunha (1992) podem acarretar muitos problemas à pavimentação, como por exemplo:

- deterioração das áreas do pavimento próximas à vala, devido à demora na recomposição ou não execução de corte das áreas afetadas (Figura 3.13A);

- ruptura do pavimento reconstituído, devido à insuficiência de espessura ou má execução (Figura 3.13B); 
- recalque do pavimento reconstituído, devido ao adensamento do solo de reaterro (Figura 3.13C);

- reconstituição do pavimento em nível acima da superfície do pavimento primitivo, causando grande desconforto aos usuários (Figura 3.13D);

- desagregação do revestimento asfáltico a quente, devido à compactação a baixa temperatura (Figura 3.13E).
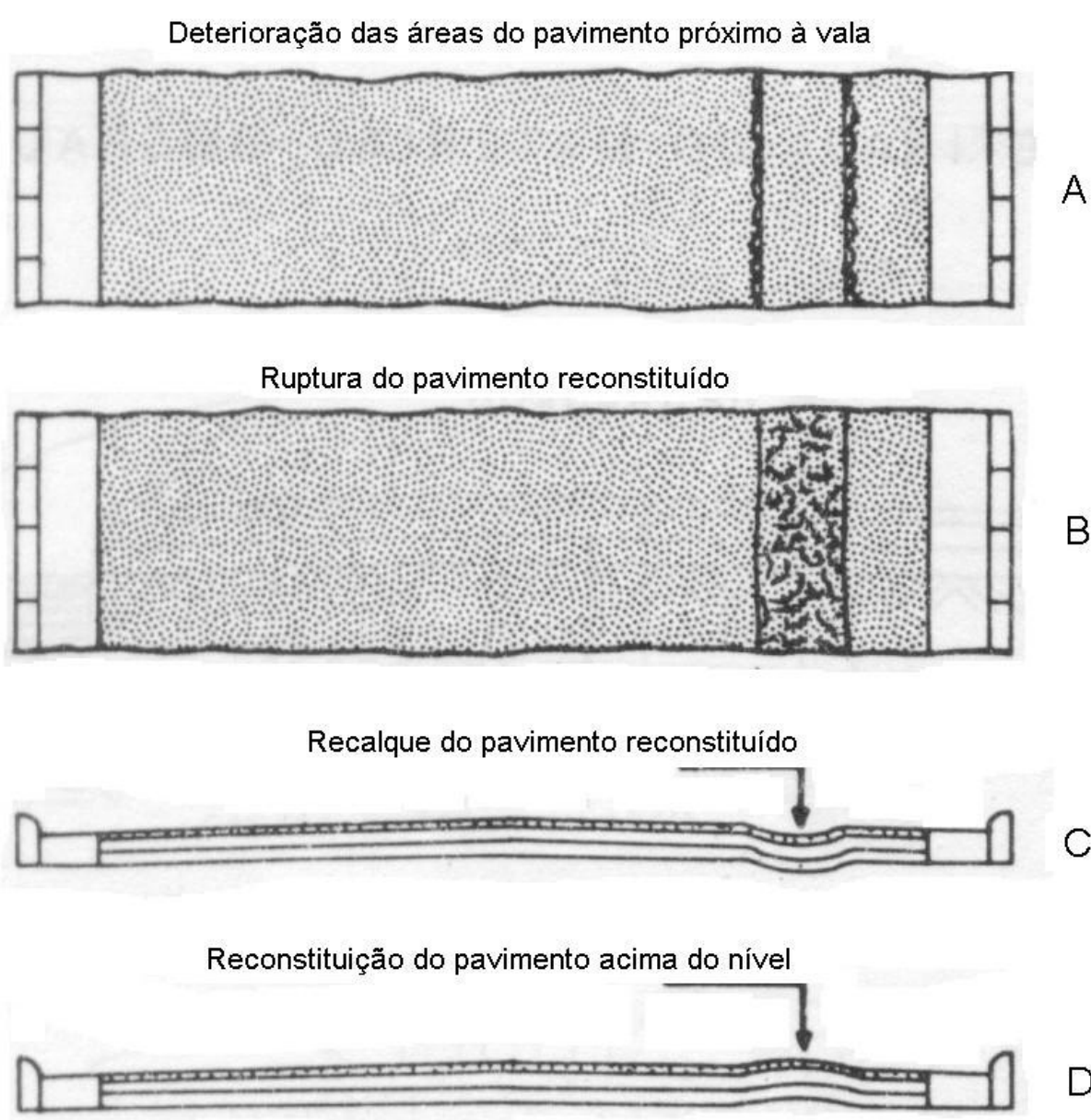

Escamação ou desagregação

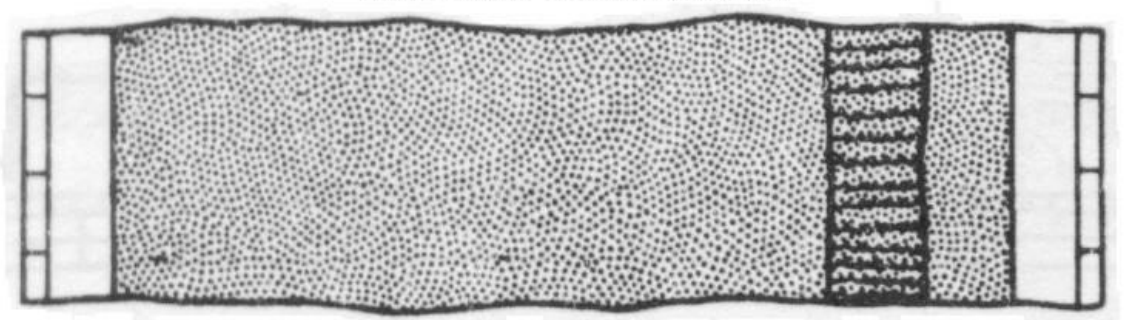

$E$

Figura 3.13 - Defeitos devidos à execução inadequada (Augusto Jr. et al.,1992) 


\section{5 - PROCESSO DE REPARO ADEQUADO}

$\mathrm{Na}$ escolha do processo de reparo, Augusto Jr. et al. (1992) observam que os seguintes fatores devem ser considerados:

- o tempo de execução do reparo deve ser o mais breve possível, pois toda interrupção significa risco para o usuário ;

- os trechos a serem reparados devem ser os mais curtos possíveis, para não causar transtorno aos que utilizam a via;

- as mudanças freqüentes na cor do pavimento, bem como o emprego de materiais diferentes do restante do revestimento, devem ser evitados (conforto visual).

- a superfície do pavimento remanescente deve ter seu reparo nivelado, evitando, deste modo, superfícies irregulares (conforto auditivo); 


\section{4 - GERÊNCIA DE PAVIMENTOS URBANOS}

\section{1 - INTRODUÇÃO}

A gerência de pavimentos, segundo Haas, Hudson e Zaniewski (1994), envolve a identificação de estratégias ótimas nos vários níveis de gerenciamento, assim como a implementação das mesmas, sendo um processo que abrange todas atividades envolvidas com o propósito de fornecer e manter pavimentos em nível adequado de serviço. Suas atividades incluem desde a obtenção inicial de informações para o planejamento e elaboração de orçamento até a monitorização periódica do pavimento em serviço, passando pelo projeto e construção do pavimento e sua manutenção e reabilitação ao longo do tempo (Fernandes Jr.,1996).

As atividades e componentes dos sistemas de gerência de pavimento estão caracterizados, geralmente, em dois níveis administrativos: a gerência em nível de rede e em nível de projeto (Figura 4.1).

A gerência em nível de rede trabalha com informações resumidas, relacionadas à malha inteira das vias, utilizadas para a tomada de decisões, essencialmente administrativas, sobre as atividades de planejamento, programação e orçamento.

A gerência de pavimentos em nível de projeto envolve o dimensionamento, construção, manutenção e reabilitação do pavimento. Trabalha com informações técnicas detalhadas, relacionadas a seções 
específicas do pavimento. A gerência em nível de projeto permite uma análise detalhada da programação de intervenções no pavimento e inclui um diagnóstico detalhado dos defeitos, suas causas prováveis e métodos corretivos alternativos.

Um Sistema de Gerência de Pavimentos completo funciona em todos os níveis, desde o nível de projeto mais fundamental até o nível administrativo mais alto. Em cada um desses níveis, tipos diferentes de decisão são solicitados em função dos dados disponíveis, dos critérios e das restrições. No entanto, o fluxo básico de informações ou seqüência de ações dentro dos níveis é o mesmo.

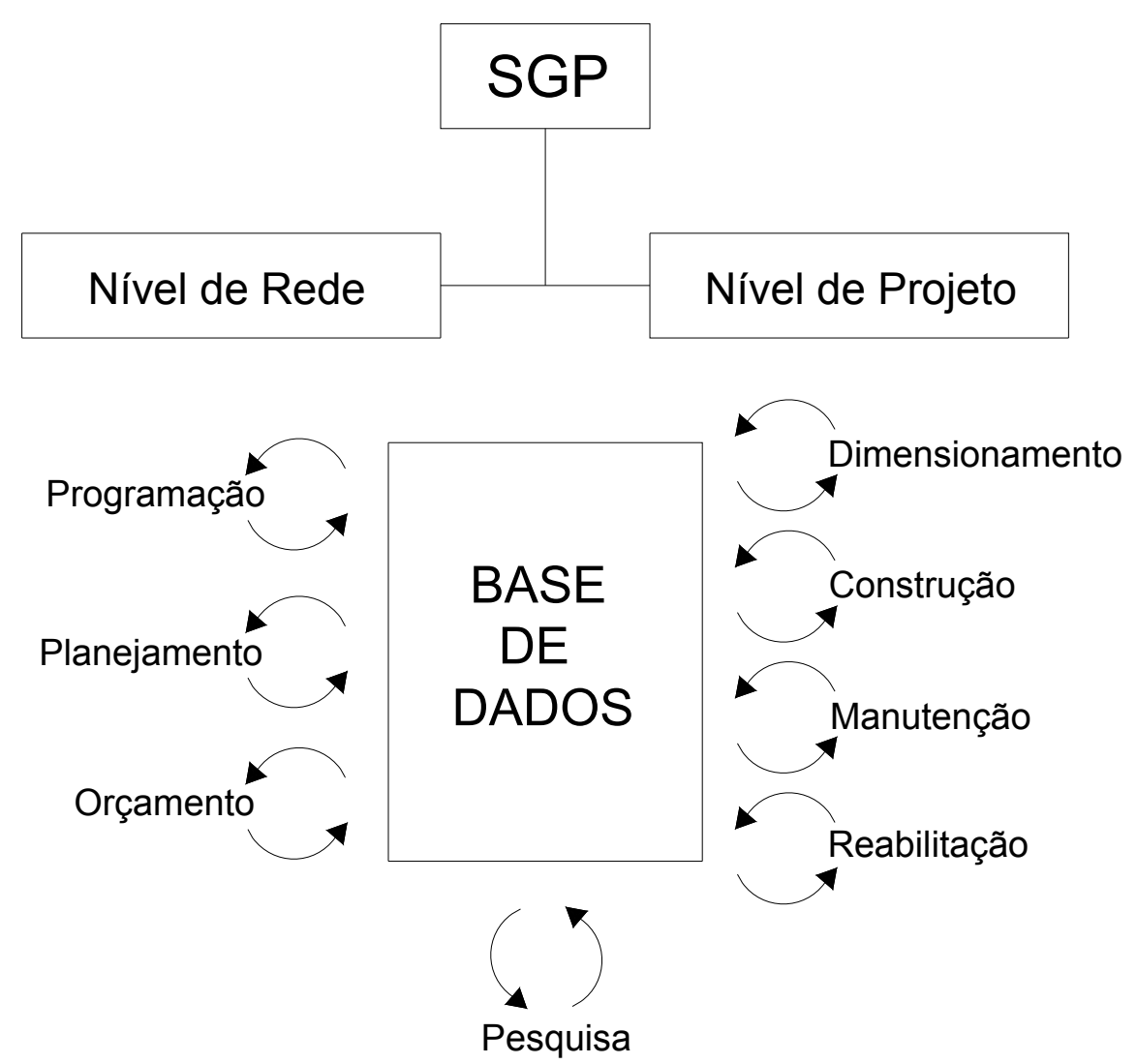

Figura 4.1 - Fluxograma dos componentes de um sistema de gerência de pavimentos em nível de rede e projeto (Haas et al. 1994).

Os Sistemas de Gerência de Pavimentos Urbanos (SGPU) apresentam muitas características distintas das que são apresentadas pelos sistemas de gerência de pavimentos tradicionalmente utilizados pelos organismos rodoviários federais e estaduais. 
Uma das principais diferenças, destacada por Fernandes Jr. e Bertollo (1997), é o grande número de redes de infra-estrutura públicas que correm paralelas ou cruzando o pavimento das vias urbanas, promovendo intervenções no pavimento para sua construção e manutenção.

\section{2 - DESENVOLVIMENTO DE UM SGPU}

Em um país como o Brasil, onde os recursos são escassos e nitidamente inferiores às necessidades, não é admissível que se desperdice dinheiro e, nesse sentido, os sistemas de gerência de pavimentos (SGP) são alternativas para a otimização dos recursos e garantia de boas condições para as vias públicas. Para tanto, é necessária uma abordagem organizada e sistemática, mas ao mesmo tempo compatível com os serviços do dia-a-dia do organismo rodoviário.

Um SGP é uma ferramenta que facilita a tomada de decisão, de maneira que o tempo e o custo sejam otimizados. Porém, às vezes pode parecer complicado, pois utiliza programas computacionais e análises financeiras para a elaboração de relatórios. Essa aparente dificuldade do SGP pode frustrar as pessoas envolvidas e diminuir o entusiasmo para a sua adoção e uso continuado. Além disso, o apoio político é indispensável tanto para a implementação quanto para a manutenção da equipe técnica ao longo do tempo, livre das perturbações causadas pela alternância político-partidária.

As etapas do desenvolvimento de um Sistema de Gerência de Pavimentos para cidades de pequeno e médio porte, segundo MAPC (1986), são mostradas na Figura 4.2. 


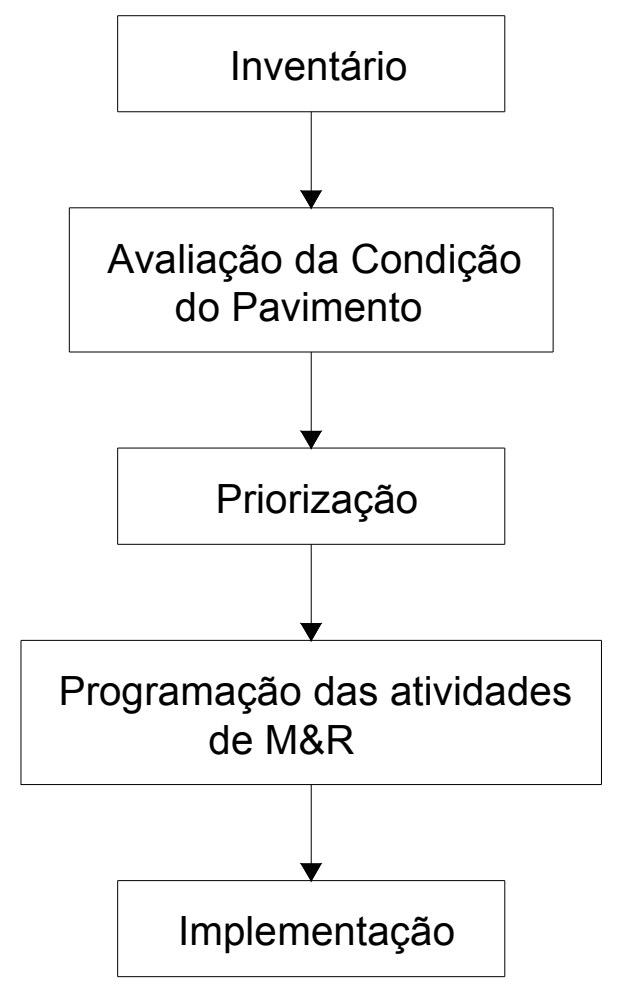

Figura 4.2- Etapas da implantação de um SGPU (MAPC, 1986).

\subsection{1 - INVENTÁRIO}

O inventário é o processo de coleta e organização dos dados para a implementação apropriada de um programa de gerência de pavimentos. Do inventário devem constar mapas com todas as ruas mantidas pelo município e arquivos sobre projetos de construção, datas das intervenções de manutenção e reabilitação, comprimento, largura e tipo de pavimento (FHWA, 1989).

O primeiro passo de um inventário é dividir a malha viária em seções. Segundo Pantigoso (1998), no caso de vias urbanas, estas podem ser divididas em seções usando as interseções ou quarteirões. Uma consideração importante é a forma em que o pavimento é contabilizado dentro da área das interseções. Nas áreas urbanas, as interseções podem significar uma porção importante da área total de pavimento. Existem três métodos para definir a área das interseções, evitando-se a duplicidade de consideração:

- as áreas das interseções devem ser tratadas como seções separadas; 
- em cidades em que a orientação das ruas é uma grelha retangular, uma designação pode ser feita de tal forma que as seções incluam as interseções;

- as classes funcionais das ruas podem ser usadas para definir a que seção pertence a interseção.

No caso das cidades brasileiras de pequeno e médio porte, o inventário deve ser tão simples quanto possível, facilitando a coleta das informações necessárias (Bertollo, 1997). O inventário da rede urbana pavimentada deve conter os seguintes dados:

- descrição das seções: deve incluir o código de identificação, o nome e classe funcional da rua à qual a seção pertence e o tipo de pavimento;

- características geométricas: comprimento, largura, número de faixas, espessura e materiais do pavimento;

- dados históricos: devem conter o ano de construção, datas e tipos de manutenções sucessivas (recapeamentos, reconstruções), assim como dados de custos;

- tráfego: deve incluir a capacidade da via, o tráfego diário médio, a taxa de crescimento e a porcentagem de caminhões.

\subsection{2 - AVALIAÇÃO DA CONDIÇÃO dOS PAVIMENTOS}

A avaliação da condição dos pavimentos pode ser feita tanto por meio de uma avaliação subjetiva quanto por uma avaliação objetiva.

A avaliação subjetiva está baseada no conceito de serventia, apresentado por Carey e Irick (1960) quando do AASHO Road Test. Quando do desenvolvimento deste conceito, consideraram as seguintes hipóteses: 
- o propósito principal de uma rodovia é servir ao público que viaja sobre ela;

- a opinião dos usuários é subjetiva;

- existem algumas características das rodovias que podem ser medidas objetivamente e que podem ser relacionadas com a opinião dos usuários;

- a serventia de uma seção de rodovia pode ser expressa através de avaliações realizadas pelos usuários;

- o desempenho de um pavimento é o histórico de sua serventia ao longo do tempo.

A capacidade de um pavimento servir satisfatoriamente ao tráfego durante um período de tempo é caracterizada como o seu desempenho, que pode ser interpretado como a variação da serventia com o tempo e/ou tráfego (Figura 4.3).

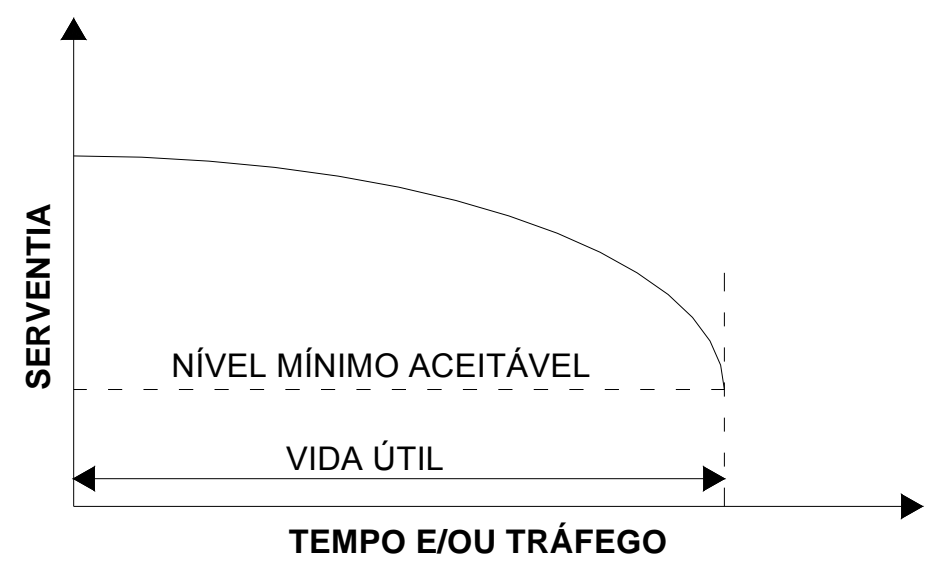

Figura 4.3 - Conceito de serventia-desempenho (CAREY \& IRICK, 1960).

$\mathrm{Na}$ avaliação objetiva, considerando a gerência em nível de rede, os pavimentos urbanos podem ser avaliados apenas por levantamento de defeitos no campo, mediante inspeção visual, conforme apresentado por Bertollo (1997). 
O reconhecimento do tipo de defeito, a quantificação da sua extensão e identificação do nível de severidade e determinação das causas dos defeitos são de vital importância para a seleção das estratégias de intervenção e definição das atividades de manutenção e reabilitação.

Fernandes Jr. e Bertollo (1997) recomendam a adoção do manual de levantamento de campo utilizado no Programa SHRP em virtude da necessidade de uniformização da coleta de dados e, principalmente, do compromisso dos países envolvidos com o programa SHRP para o acompanhamento do desempenho das seções ao longo do tempo.

Dentre os 15 defeitos considerados pelo Programa SHRP (1993b), nem todos são observados com freqüência em vias urbanas, como é o caso das trincas transversais, dos agregados polidos, do desnível pista pavimento e do bombeamento. A Tabela 4.1 apresenta o elenco de defeitos observados em vias urbanas e suas principais características.

\subsection{3 - PRIORIZAÇÃO}

Após o levantamento e avaliação da condição do pavimento, determinadas as necessidades, precisa-se estabelecer prioridades para as atividades de manutenção e reabilitação, pois geralmente os recursos são menores que as necessidades.

As prioridades em gerência de pavimentos podem ser determinadas por vários métodos, que vão da simples hierarquização subjetiva até a otimização, baseada em modelos de programação matemática, passando pelo uso de índices de priorização calculados em função de fatores que condicionam o desempenho dos pavimentos e dos custos.

Para a gerência de pavimentos urbanos em nível de rede, a melhor alternativa é a utilização de índices ou matrizes de priorização, desenvolvidas, muitas vezes, com base na opinião de especialistas, que selecionam os fatores intervenientes e os níveis correspondentes. 
Tabela 4.1 - Identificação de defeitos nos pavimentos (SHRP, 1993b).

\begin{tabular}{|c|c|}
\hline Defeito & Característica \\
\hline $\begin{array}{l}\text { Trincas por fadiga do } \\
\text { revestimento }\end{array}$ & $\begin{array}{l}\text { - Áreas submetidas a cargas repetidas de tráfego. } \\
\text { - Forma: "couro de crocodilo" ou "tela de galinheiro". } \\
\text { - Espaçamento inferior a } 30 \mathrm{~cm} \text {. }\end{array}$ \\
\hline Trincas em blocos & $\begin{array}{l}\text { - Trincas que dividem o pavimento em pedaços } \\
\text { aproximadamente retangulares. } \\
\text { - Tamanho dos blocos: 0,1 a } 10 \mathrm{~m}^{2} \text {. }\end{array}$ \\
\hline Defeitos nos bordos & $\begin{array}{l}\text { - Apenas para pavimentos com acostamentos não } \\
\text { pavimentados. } \\
\text { - Dentro de uma faixa de } 60 \mathrm{~cm} \text { a partir da extremidade } \\
\text { do pavimento. }\end{array}$ \\
\hline Trincas longitudinais & $\begin{array}{l}\text { - Trincas predominantemente paralelas ao eixo, podendo } \\
\text { se localizar dentro ou fora das trilhas de roda. }\end{array}$ \\
\hline Trincas por reflexão & $\begin{array}{l}\text { - Reflexão de trincas ou juntas das camadas inferiores. } \\
\text { - Recapeamento ou pavimentos novos (contração da } \\
\text { base). }\end{array}$ \\
\hline Remendos & $\begin{array}{l}\text { - Porção da superfície do pavimento, maior que } 0,10 \mathrm{~m}^{2} \text {, } \\
\text { removida e substituída ou material aplicado ao } \\
\text { pavimento após a construção inicial. }\end{array}$ \\
\hline Panelas & $\begin{array}{l}\text { - Buracos resultantes de desintegração localizada, sob a } \\
\text { ação do tráfego e em presença de água. } \\
\text { - Fragmentação, causada por trincas por fadiga ou } \\
\text { desgaste, e remoção localizada de partes do } \\
\text { revestimento. }\end{array}$ \\
\hline Deformação permanente & $\begin{array}{l}\text { Depressão longitudinal nas trilhas de roda, em razão de } \\
\text { densificação dos materiais ou ruptura por cisalhamento. }\end{array}$ \\
\hline Corrugação & $\begin{array}{l}\text { - Deformação plástica caracterizada pela formação de } \\
\text { ondulações transversais na superfície do pavimento. } \\
\text { - Causada por esforços tangenciais (frenagem ou } \\
\text { aceleração). }\end{array}$ \\
\hline Exsudação & $\begin{array}{l}\text { - Excesso de ligante betuminoso na superfície do } \\
\text { pavimento. }\end{array}$ \\
\hline Desgaste & $\begin{array}{l}\text { - Perda de adesividade do ligante betuminoso e } \\
\text { desalojamento dos agregados. } \\
\text { - Envelhecimento, endurecimento, oxidação, volatilização, } \\
\text { intemperização. }\end{array}$ \\
\hline
\end{tabular}




\subsection{4 - ATIVIDADES DE MANUTENÇÃO E REABILITAÇÃO}

Fernandes Jr., Oda e Zerbini (2001) salientam que as atividades de manutenção têm por objetivo preservar ou manter o período de projeto do pavimento, aumentando pouco o nível de serventia, mas evitando a deterioração precoce. A reabilitação, por sua vez, tem o propósito de prolongar a vida em serviço do pavimento, elevando o nível de serventia próximo ao valor máximo e criando condições para um novo ciclo de deterioração.

As atividades de manutenção podem ser divididas em duas categorias: preventivas e corretivas. A manutenção preventiva consiste do grupo de atividades realizadas para proteger o pavimento e reduzir a sua taxa de deterioração, enquanto que as atividades corretivas têm como objetivo eliminar um determinado tipo de defeito.

\section{3 - SGPU NA CIDADE DE SÃO CARLOS - SP}

Em estudo de caso realizado na cidade de São Carlos, cidade brasileira de médio porte, Zanchetta (2005) analisa o processo de implantação de um SGPU, tendo sido consideradas apenas as seções com pavimento flexível.

A Tabela 4.2 mostra dados referentes aos valores de ICP (Índice de Condição do Pavimento) subjetivo e calculado e o conceito associado a cada intervalo, o qual varia de muito ruim a muito bom. Apresentam-se, também, as estratégias de manutenção e reabilitação (M\&R) mais indicadas em cada intervalo de variação dos valores de ICP subjetivo.

Com esses resultados pode-se dizer que a malha urbana de São Carlos ainda está num estágio em que a maior parte dos esforços estão na conservação e apenas uma pequena parte realmente necessita de reabilitação. Lima et al. (2004) destacam esse fato, pois os custos de reabilitação são muito maiores do que os de manutenção. 
Tabela 4.2 - Distribuição percentual da condição dos pavimentos da cidade de São Carlos e das estratégias de M\&R (Zanchetta, 2005).

\begin{tabular}{|c|c|c|c|c|c|}
\hline \multirow{2}{*}{\multicolumn{2}{|c|}{ CONDIÇÃO DO PAVIMENTO }} & \multicolumn{2}{|c|}{ ICP } & \multicolumn{2}{|c|}{ M\&R } \\
\hline & & SUBJETIVO & CALCULADO & ESTRATÉGIA & $\%$ \\
\hline $\begin{array}{c}\mathrm{ICP} \geq 90 \\
80 \leq \mathrm{ICP}<90\end{array}$ & $\begin{array}{c}\text { muito boa } \\
\text { boa }\end{array}$ & 82,2 & 89,2 & NF & 85,7 \\
\hline $70 \leq \mathrm{ICP}<80$ & regular & 15,0 & 9,7 & MC e MP & 12,3 \\
\hline $60 \leq \mathrm{ICP}<70$ & ruim & 2,0 & 1,0 & RF & 1,5 \\
\hline $\mathrm{ICP}<60$ & muito ruim & 0,8 & 0,1 & $\mathrm{RC}$ & 0,5 \\
\hline $\begin{array}{l}\mathrm{NF}=\text { não fazer } \mathrm{n} \\
\mathrm{MC}=\text { manutençã } \\
\mathrm{MP}=\text { manutençã }\end{array}$ & $\begin{array}{l}\text { lada } \\
\text { áo corretiva } \\
\text { áo preventiva }\end{array}$ & & $\begin{array}{l}=\text { reforço } \epsilon \\
=\text { reconstr }\end{array}$ & $\begin{array}{l}\text { rutural } \\
\text { ão }\end{array}$ & \\
\hline
\end{tabular}

A Tabela 4.3 mostra, de forma resumida, a condição da malha viária urbana de São Carlos, com dados referentes aos defeitos encontrados. Os desgastes e os remendos são os defeitos mais presentes, sendo que as trincas por reflexão e trincas em blocos, são os menos freqüentes.

Tabela 4.3 - Resumo dos defeitos presentes na malha urbana de São Carlos (Zanchetta, 2005).

\begin{tabular}{lcccc}
\hline \multirow{2}{*}{ Defeitos } & \multicolumn{2}{c}{ Nível de Severidade dos Defeitos } & Total de seções \\
\cline { 2 - 4 } & Baixo & Médio & Alto & com defeito \\
\hline Trinca por fadiga & 1780 & 1321 & 474 & 2257 \\
Trinca em bloco & 38 & 19 & 1 & 58 \\
Defeito nos bordos & 663 & 334 & 185 & 1043 \\
Trinca longitudinal & 213 & 81 & 30 & 292 \\
Trinca por reflexão & 18 & 6 & 3 & 27 \\
Remendo & 3400 & 2763 & 557 & 4548 \\
Panela & 1058 & 709 & 518 & 1843 \\
Deformação permanente & 449 & 241 & 78 & 699 \\
Corrugação & 45 & 27 & 223 & 95 \\
Exudação & 114 & 52 & 16 & 182 \\
Desgaste & 5302 & 3563 & 1800 & 5602 \\
\hline
\end{tabular}


A Figura 4.4 mostra um mapa temático gerado pelo SIG-T, onde se destacam os índices de prioridade. Segundo Zanchetta (2005), essa potencialidade pode ser utilizada pelos administradores públicos para apresentar e justificar para a sociedade os locais que necessitam de maiores investimentos. Deve-se destacar que essa maneira de apresentação dos dados é de fácil entendimento por todos.

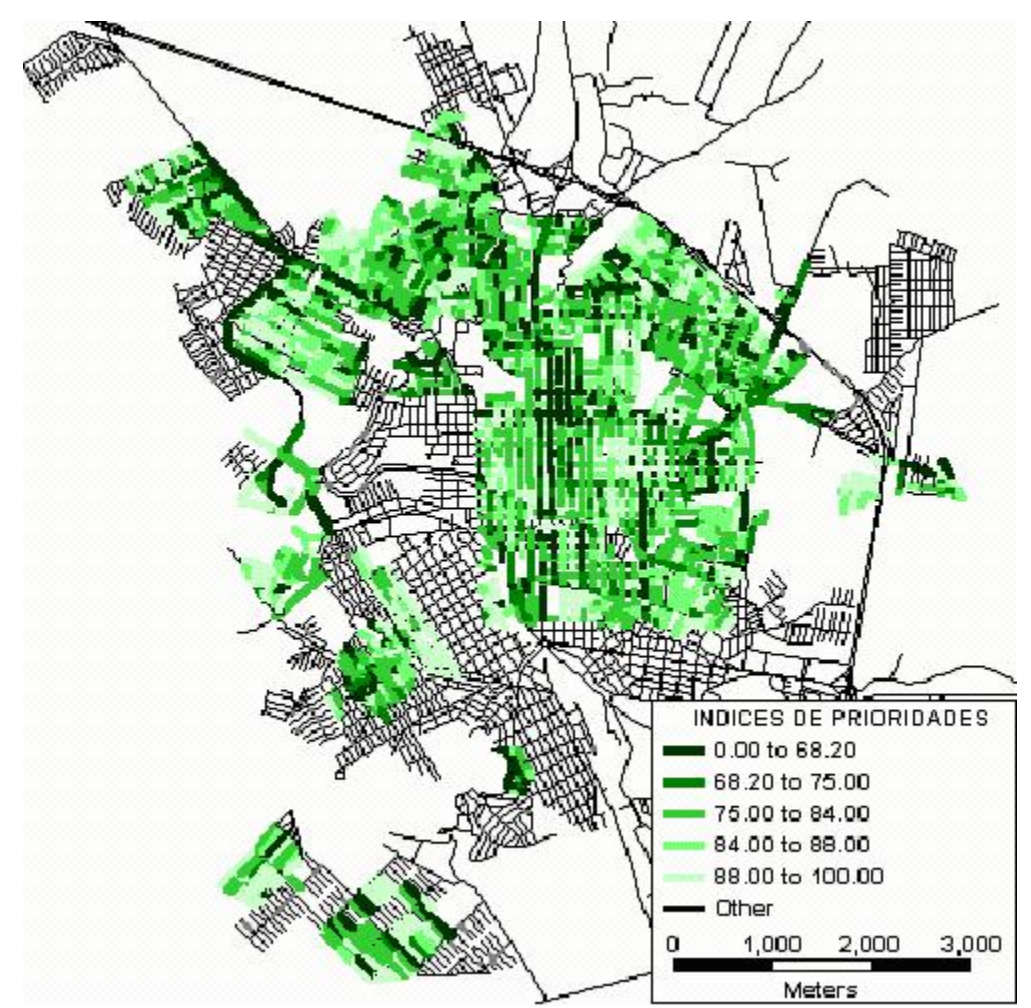

Figura 4.4 - Mapa temático contendo índices de prioridades de algumas seções da cidade de São Carlos (Zanchetta, 2005).

A Tabela 4.4 mostra os resultados referentes às intervenções no pavimento por empresas públicas, autônomas ou privadas, tais como água e esgoto, telefonia e energia elétrica. O grau de interferência é dado da seguinte maneira:

- baixo - para seções com nível de interferência de até $5 \%$ em relação a área total da seção;

- médio - para seções com nível de interferência entre 6 e 10\%;

- alto - para seções com mais de $10 \%$ de interferência. 
Tabela 4.4 - Intervenção no pavimento (Zanchetta, 2005).

\begin{tabular}{ccc}
\hline Grau de Interferência & $\%$ & $\mathrm{n}^{\circ}$ absoluto de seções \\
\hline Baixo (B) & 63,35 & 3674 \\
Médio (M) & 24,05 & 1395 \\
Alto (A) & 12,60 & 731 \\
\hline
\end{tabular}

As intervenções diminuem a serventia da via $e$, nem sempre os remendos são realizados da forma correta, deixando o pavimento com pequenas depressões ou saliências, possibilitando o surgimento precoce de outros defeitos e aumentando o custo para a sociedade.

A Figura 4.5 mostra uma seção de um bairro recém pavimentado, com um alto nível de interferência do SAAE, sendo que várias outras seções no bairro possuem o mesmo problema.

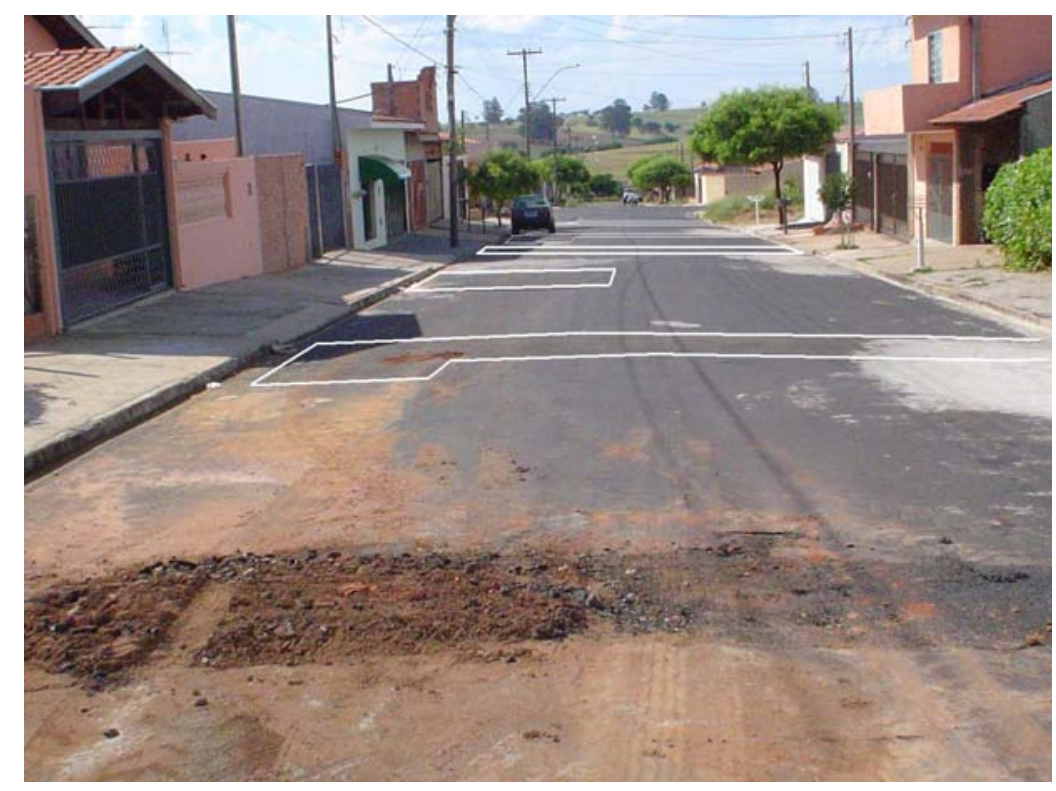

Figura 4.5 - Excesso de interferência do SAAE (Zanchetta, 2005).

Zanchetta (2005) destaca a necessidade de uma maior interação entre a prefeitura e as empresas prestadoras de serviço público, para se evitar a deterioração precoce dos pavimentos por falta exclusiva de comunicação e planejamento. Salienta, ainda, que a implantação de infra-estrutura básica antes da execução dos serviços de pavimentação, embora óbvia, nem sempre ocorre. 


\section{5 - ESTUDO DE CASO}

\section{1 - INTRODUÇÃO}

Esta dissertação tem por objetivo principal investigar alternativas para solucionar os problemas de pavimentação urbana causados por intervenções das redes de abastecimento de água e esgoto. Estudar, em nível de rede, possibilidades de compatibilizar a gerência de pavimentos com a gerência de outras infra-estruturas urbanas. E, em nível de projeto, avaliar as normas de execução dos serviços, os métodos de execução efetivamente utilizados e os critérios de recebimento dos serviços.

Para o desenvolvimento desta pesquisa, o primeiro passo foi o levantamento das práticas usualmente adotadas pela Prefeitura Municipal de São Carlos (PMSC) e pelas concessionárias de serviços públicos da cidade, principalmente do Serviço Autônomo de Água e Esgoto (SAAE), para o estabelecimento de programas de manutenção e reabilitação de pavimentos urbanos. Não existindo um trabalho integrado entre a Secretaria Municipal de Transporte, Trânsito e Vias Públicas (SMTTVP) e as Concessionárias de Serviços Públicos, destacando-se que as concessionárias têm total autonomia sobre seus serviços, estabeleceu-se um contato direto com o SAAE.

Formalizado o acompanhamento das obras de intervenção nos pavimentos feitas ou supervisionadas pelo SAAE, iniciou-se a coleta de 
informações necessárias para o desenvolvimento deste trabalho, sendo analisadas as interferências executadas no período de 2002 a 2004.

Posteriormente, para o enriquecimento do trabalho, foram coletados dados junto ao Departamento Autônomo de Água e Esgoto (DAAE) de Araraquara, com o intuito de comparar os procedimentos de manutenção adotados nestas duas cidades.
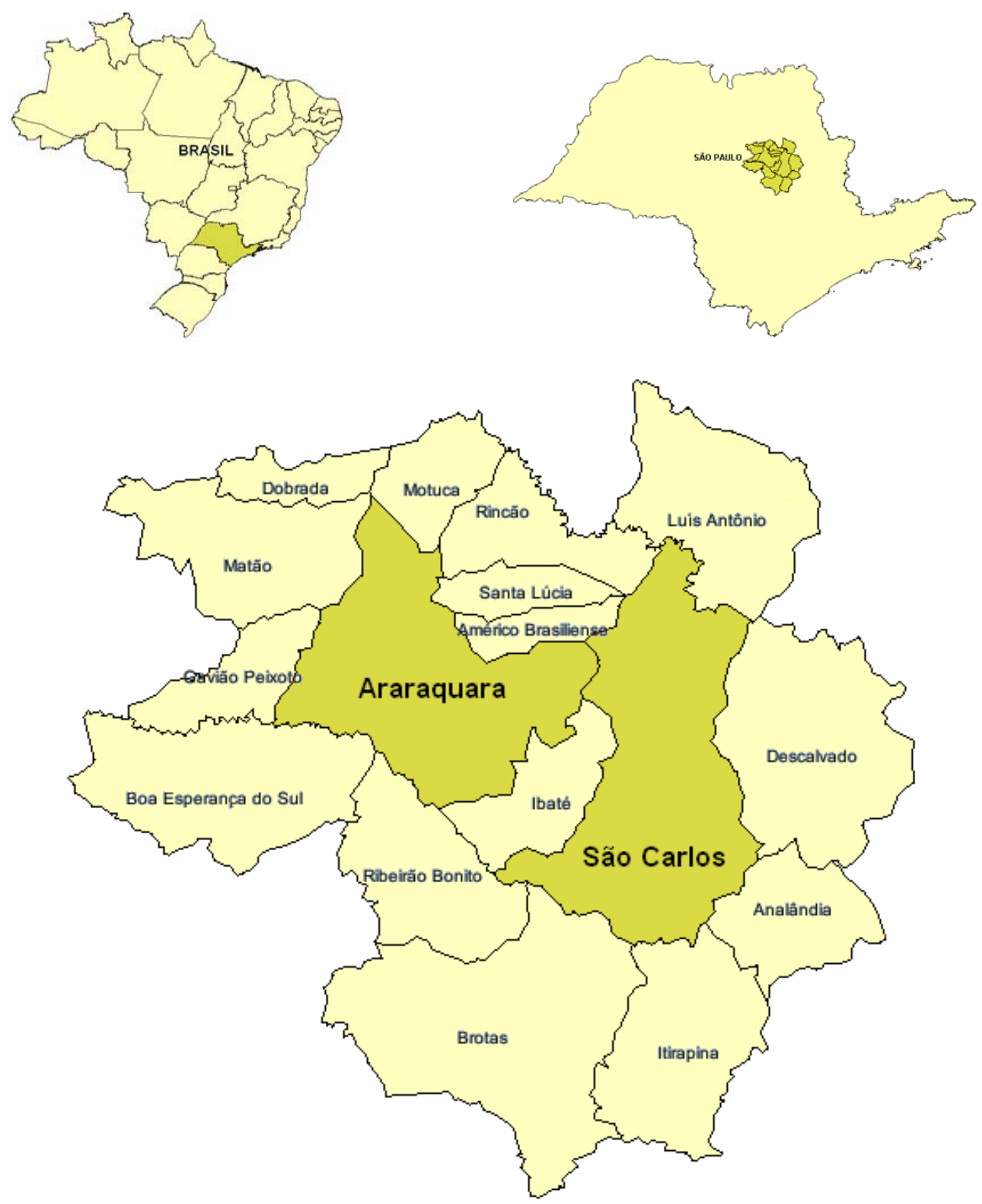

Figura 5.1- Localização das Cidades de São Carlos e Araraquara. 


\section{2 - A CIDADE DE SÃO CARLOS}

São Carlos localiza-se na região central do estado de São Paulo, a 225km da capital, na Região Sudeste do Brasil (Figura 5.1), possuindo uma área total de $1.141 \mathrm{~km}^{2}$. Tem aproximadamente 200.000 habitantes. Possui clima predominantemente tropical, com temperaturas médias variando entre $16,2^{\circ} \mathrm{C}$ (mínima) e $26,9^{\circ} \mathrm{C}$ (máxima), estando posicionada na latitude $22,02^{\circ}$ sul e longitude $47,89^{\circ}$ oeste (IBGE, 2000).

A situação da cidade de São Carlos, provavelmente igual à da maioria das cidades brasileiras, geralmente a cada nova administração não se procura dar continuidade ao trabalho desenvolvido anteriormente. Há, sempre, uma enorme dificuldade para obtenção de informações junto aos órgãos competentes. Atualmente existe um banco de dados específico para a malha viária, mas os mapas, que constituem uma importante fonte de informação, estão quase todos desatualizados.

\subsection{1 - Secretaria Municipal de Transporte, Trânsito e Vias PÚBLICAS}

A Secretaria Municipal de Transporte, Trânsito e Vias Públicas (SMTTVP) atua na construção e conservação de vias públicas urbanas, na execução das várias modalidades de transporte público e na operação, fiscalização e coordenação do sistema de trânsito, sendo responsável pela sinalização viária. Também executa a abertura e conservação de estradas e caminhos municipais, o transporte escolar urbano e rural e a fiscalização dos serviços de transporte público, de ônibus, táxi e outros. Desenvolve projetos de educação para o trânsito, em conjunto com a Secretaria Municipal de Educação e Cultura e ainda administra a Usina de Asfalto que produz material de pavimentação e da usina de pré-moldados que produzem materiais para atendimento da demanda da Secretaria. 
Com o objetivo de alcançar segurança, confiabilidade e eficiência, o Departamento de Transportes Públicos estuda, planeja e opera o sistema de transportes do município, além de administrar, controlar e fiscalizar a execução do contrato de concessão do transporte coletivo.

O ordenamento do trânsito na cidade é a proposta de trabalho do Departamento de Trânsito. Para isso, realiza operações de trânsito, desenvolve projetos de intervenção de segurança viária, implanta sinalização e gerencia o pátio municipal de recolhimento de veículos. Realiza também ações de conscientização e educação e disponibiliza banco de dados sobre estatísticas de acidentes.

Entre as atribuições do Departamento de Infra-Estrutura Viária estão fiscalizar e executar os serviços gerais da manutenção das vias e o levantamento da situação da rede viária. A autorização para ocupação das vias públicas também é responsabilidade deste órgão, assim como a organização do cadastro de instalações e equipamentos.

Atualmente, há um elevado grau de insatisfação por parte dos usuários da malha viária de São Carlos, devido, principalmente, à falta de manutenção periódica. Quanto à gerência das atividades de pavimentação, a seleção das ruas para manutenção e reabilitação geralmente ocorre a partir da reclamação dos moradores.

A prefeitura municipal de São Carlos procura iniciar os serviços pelos corredores com maior intensidade de trânsito e, em seguida, passa às vias secundárias. A definição do tipo de serviço a executar é feita por funcionários mais antigos, que já conhecem bem a malha viária. Os serviços executados consistem, basicamente, de "tapa-buracos" e recapeamentos, executados por empresas terceirizadas. Geralmente não é feito controle tecnológico e não há um acompanhamento dos custos ao longo do tempo.

No momento, não existe um trabalho coordenado entre a prefeitura e as concessionárias de serviços públicos. Dessa forma, as valas abertas para manutenção, remodelação e ampliação da rede de água e esgoto são de inteira responsabilidade do SAAE. A Figura 5.2 mostra o mapa viário da cidade de São Carlos. 


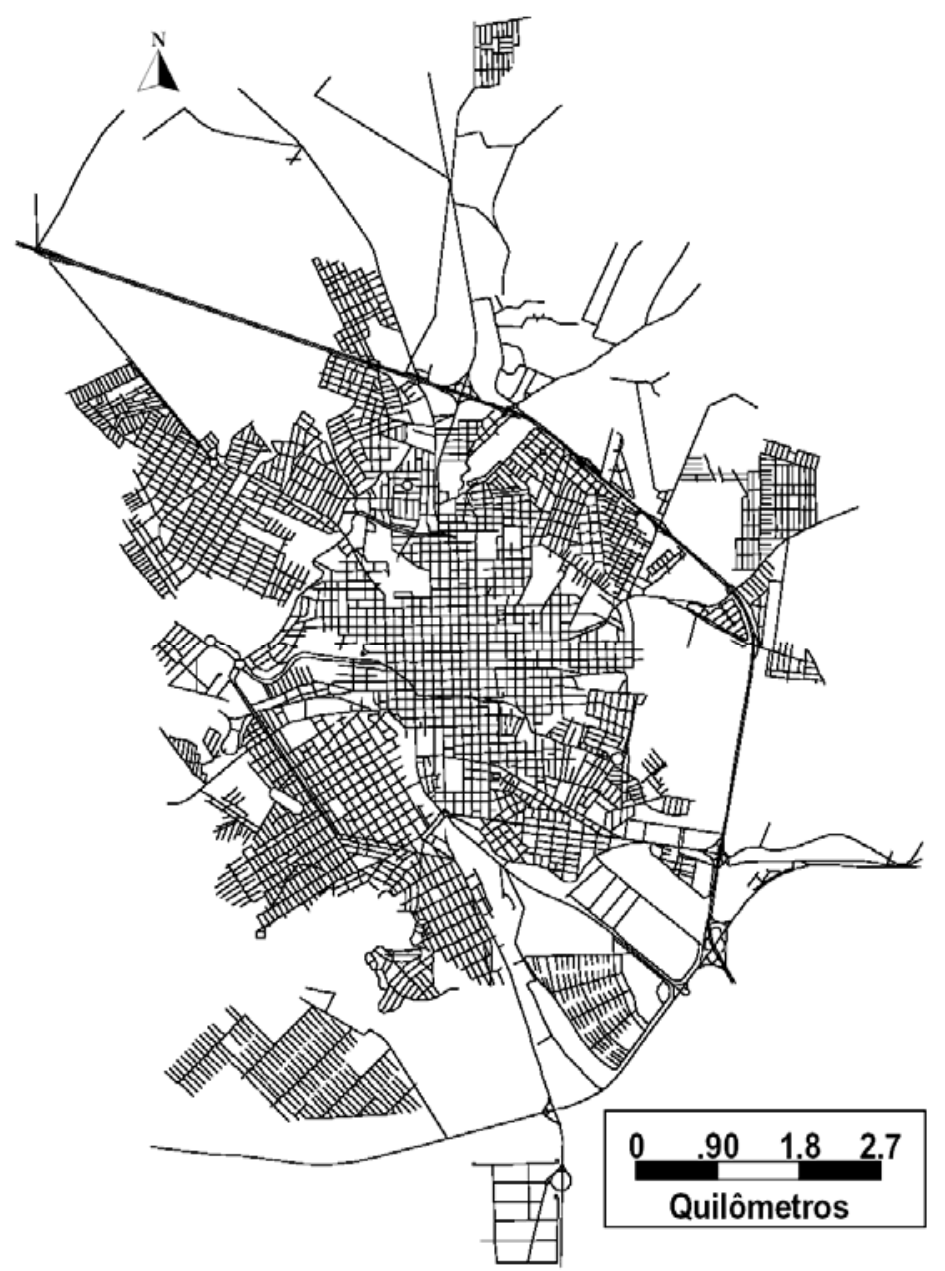

Figura 5.2- Sistema viário de São Carlos.

\subsection{2 - Serviço Autônomo de Água e Esgoto}

O Serviço Autônomo de Água e Esgoto (SAAE) de São Carlos foi criado pela Lei Municipal n. 6199, de 26/06/69, exercendo a sua ação em todo o município de São Carlos, sendo que Ihe compete estudar, projetar e executar, diretamente ou mediante contrato com organizações especializadas em engenharia sanitária, as obras relativas à construção, ampliação ou remodelação dos sistemas públicos de abastecimento de água potável e de esgotos sanitários que não forem objetos de convênio entre a Prefeitura e os Órgãos Federais ou Estaduais específicos.

O SAAE também atua como órgão coordenador e fiscalizador da execução dos convênios firmados entre o Município e os Órgãos Federais ou 
Estaduais para estudos, projetos e obras de construção, ampliação ou remodelação dos serviços públicos de abastecimento de água e esgotos sanitários.

Além disso, o SAAE opera, mantém, conserva e explora, diretamente, os serviços de água potável e de esgotos sanitários; lança, fiscaliza e arrecada as tarifas dos serviços de água e esgotos e as tarifas de contribuição que incidirem sobre os terrenos beneficiados com tais serviços, exercendo, também, quaisquer outras atividades relacionadas com os sistemas públicos de água e esgotos, compatíveis com leis gerais e especiais.

O SAAE atualmente possui o cadastro das redes de água e esgoto da cidade de São Carlos, em forma de mapas, em escala 1:2000, contendo localizações das redes, poços de inspeção e diâmetros. Porém, o cadastro da rede de distribuição encontra-se desatualizado. Não existe registro de idade, principalmente das tubulações mais antigas do centro da cidade.

Os mapas cadastrais das redes de distribuição de água e esgoto foram confeccionados com base em informações de funcionários e cobrem cerca de 98\% da área urbana. Por não se encontrarem referenciados a nenhum sistema de coordenadas geográficas, esses mapas não apresentam os recursos necessários para uma localização precisa dos seus componentes.

O cadastro da rede é feito, atualmente, quando da abertura de valas para ligações de água e esgoto, sendo conferida a condição da rede, sua localização, tipo de material, profundidade e estado de conservação.

Não existe um planejamento de manutenção da rede, que é feita através de reclamações da população. As atividades de manutenção consistem, basicamente, em reparos de vazamentos, trocas de registros, mudanças de ligações, substituições de redes de água e esgoto, conjuntos eletro-mecânicos e proteção de mananciais.

Os principais problemas, que provocam as reclamações da população, são: vazamento de água na rede; vazamento de água na calçada; esgoto entupido; retorno de esgoto; falta de água; pouca pressão de água; qualidade da água; e, principalmente, o serviço de tapa buraco. 


\subsection{3 - COLETA DOS DADOS - SAAE SÃo CARLOS}

O serviço de tapa buraco do SAAE decorre do reparo, melhoramento ou novas instalações de redes e de ligações de água e esgoto. Optou-se, neste trabalho, por utilizar apenas informações referentes às ligações prediais de água e esgoto, por ser um serviço muito freqüente.

Atualmente, são utilizadas duas equipes formadas por funcionários do próprio SAAE que são responsáveis pelos serviços de ligações. Cada equipe é constituída por uma retro-escavadeira equipada com pá-carregadeira, seu respectivo operador, além de um encanador e um ajudante. As equipes trabalham simultaneamente e são responsáveis pelas seguintes solicitações:

- mudança de ligação de água;

- mudança de ligação de esgoto;

- mudança de ligação de água e esgoto;

- ligação de água;

- ligação de esgoto; e

- ligação de água e esgoto.

A mudança das ligações consiste na modificação do local das instalações ou na modificação dos materiais empregados nas ligações. No caso das ligações de água, geralmente ocorre a substituição de tubo galvanizado para tubo em PEAD (polietileno de alta densidade), enquanto nas ligações de esgoto substituem-se as manilhas cerâmicas pelo tubo ocre.

Levando-se em consideração a posição da rede, as ligações podem ocorrer com ou sem corte do pavimento. No caso das ligações sem corte, a rede pode encontrar-se na calçada ou com espera preparada na calçada e também em ruas de terra. Já as que ocorrem com corte de pavimento podem ser consideradas ligações longas ou curtas. As longas cortam o pavimento até o lado oposto à rua onde é feita a ligação (rede contra), enquanto nas curtas o corte é próximo (rede a favor). As Tabelas 5.1 a 5.3 apresentam os dados referentes às ligações executadas pelo SAAE, respectivamente nos anos de 2002, 2003 e 2004. 
Tabela 5.1 - Ligações executadas pelo SAAE em 2002

\begin{tabular}{|c|c|c|c|c|c|}
\hline \multirow{2}{*}{ SOLICITAÇÃO } & \multicolumn{2}{|c|}{ COM CORTE ASFÁLTICO } & \multicolumn{2}{|c|}{ SEM CORTE ASFÁLTICO } & \multirow{2}{*}{ TOTAL } \\
\hline & LONGO & CURTO & CALÇADA & TERRA & \\
\hline MUD. ÁGUA & 270 & 271 & 66 & 6 & 613 \\
\hline MUD. ESGOTO & 8 & 20 & 4 & 3 & 35 \\
\hline MUD. ÁG/ESG & 16 & 16 & 1 & 0 & 33 \\
\hline LIG. ÁGUA & 52 & 33 & 84 & 13 & 182 \\
\hline LIG. ESGOTO & 14 & 23 & 12 & 3 & 52 \\
\hline LIG. ÁG/ESG & 267 & 139 & 665 & 58 & 1129 \\
\hline TOTAL & \multicolumn{2}{|c|}{1129} & \multicolumn{2}{|c|}{915} & 2044 \\
\hline & \multicolumn{2}{|c|}{$55,2 \%$} & \multicolumn{2}{|c|}{$44,8 \%$} & $100,0 \%$ \\
\hline
\end{tabular}

Tabela 5.2 - Ligações executadas pelo SAAE em 2003

\begin{tabular}{|c|c|c|c|c|c|}
\hline \multirow{2}{*}{ SOLICITAÇÃO } & \multicolumn{2}{|c|}{ COM CORTE ASFÁLTICO } & \multicolumn{2}{|c|}{ SEM CORTE ASFÁLTICO } & \multirow{2}{*}{ TOTAL } \\
\hline & LONGO & CURTO & CALÇADA & TERRA & \\
\hline MUD. ÁGUA & 241 & 211 & 36 & 2 & 490 \\
\hline MUD. ESGOTO & 6 & 23 & 9 & 3 & 41 \\
\hline MUD. ÁG/ESG & 21 & 16 & 0 & 0 & 37 \\
\hline LIG. ÁGUA & 51 & 61 & 81 & 15 & 208 \\
\hline LIG. ESGOTO & 9 & 14 & 14 & 6 & 43 \\
\hline LIG. ÁG/ESG & 169 & 165 & 534 & 42 & 910 \\
\hline TOTAL & \multicolumn{2}{|c|}{987} & \multicolumn{2}{|c|}{742} & 1729 \\
\hline & \multicolumn{2}{|c|}{$57,1 \%$} & \multicolumn{2}{|c|}{$42,9 \%$} & $100,0 \%$ \\
\hline
\end{tabular}

Tabela 5.3 - Ligações executadas pelo SAAE em 2004

\begin{tabular}{|c|c|c|c|c|c|}
\hline \multirow{2}{*}{ SOLICITAÇÃO } & \multicolumn{2}{|c|}{ COM CORTE ASFÁLTICO } & \multicolumn{2}{|c|}{ SEM CORTE ASFÁLTICO } & \multirow{2}{*}{ TOTAL } \\
\hline & LONGO & CURTO & CALÇADA & TERRA & \\
\hline MUD. ÁGUA & 236 & 211 & 51 & 2 & 500 \\
\hline MUD. ESGOTO & 15 & 27 & 9 & 5 & 56 \\
\hline MUD. ÁG/ESG & 9 & 18 & 8 & 0 & 35 \\
\hline LIG. ÁGUA & 59 & 56 & 97 & 7 & 219 \\
\hline LIG. ESGOTO & 7 & 16 & 6 & 2 & 31 \\
\hline LIG. ÁG/ESG & 156 & 167 & 384 & 32 & 739 \\
\hline TOTAL & \multicolumn{2}{|c|}{977} & \multicolumn{2}{|c|}{603} & 1580 \\
\hline & \multicolumn{2}{|c|}{$61,8 \%$} & \multicolumn{2}{|c|}{$38,2 \%$} & $100,0 \%$ \\
\hline
\end{tabular}


O SAAE informa à Prefeitura sobre os trabalhos de manutenção que devem ser feitos, geralmente abertura de valas nos pavimentos, mas sem que exista um trabalho coordenado entre eles. A abertura de vala para reparos ou ligações de água e esgoto é feito por duas equipes formadas por funcionários do próprio SAAE. A grande maioria das valas são abertas com auxilio de retroescavadeira, ocasionando um maior estrago ao pavimento.

O trabalho de reparo no pavimento, devido à abertura de valas, é feito por uma equipe contratada, com supervisão técnica de um engenheiro do SAAE. Cabe a esse engenheiro fazer a vistoria dos serviços, indicar as correções necessárias e fazer a aprovação final.

Conforme especificações do SAAE, o material a ser utilizado na capa é o concreto betuminoso usinado a quente (CBUQ), cuja granulometria deve enquadrar-se na faixa C do DER-SP. A execução da base é feita com aplicação de brita graduada, com adição de 4\% de cimento Portland em volume, cuja faixa granulométrica recomendada é a faixa B do DER-SP.

Inicialmente é feita a marcação da área a ser cortada, sendo que o requadramento da abertura deve ser em formato de quadrilátero (Figura 5.3), sendo o corte executado com utilização de fresa ou rompedor pneumático (Figura 5.4).

Após remoção do material (Figura 5.5) e a regularização da área (Figura 5.6), efetua-se a melhoria do subleito com grau de compactação de no mínimo 95\% em relação ao Proctor normal.

No caso de reforço do subleito deve ser feita escavação com reposição do mesmo solo ou importação de solo se necessário e compactação em camadas de $15 \mathrm{~cm}$ (pelo menos 95\% do Proctor simples).

Executa-se a base de brita graduada com espessura de $15 \mathrm{~cm}$ com adição de 4\% de cimento em volume (Figura 5.7), fazendo-se a compactação com pelo menos 95\% do Proctor modificado (Figura 5.8).

Posteriormente, é feita a aplicação da pintura de ligação com emulsão de ruptura rápida, tipo RR-1C (Figura 5.9). 
A camada de rolamento é feita com CBUQ, graduação C do DER-SP, com espessura de $4 \mathrm{~cm}$. Desta forma, é efetuado o lançamento (Figura 5.10), seguido de sua regularização (Figura 5.11).

A compactação do revestimento é praticada com rolo compactador (Figura 5.12), enquanto que nas laterais é feita com placa vibratória (Figura 5.13). Desta forma verifica-se a qualidade do serviço final (Figura 5.14). Caso o reparo seja reprovado pela fiscalização, a empresa fica obrigada a refazer o serviço até que se atinja a qualidade desejada. 


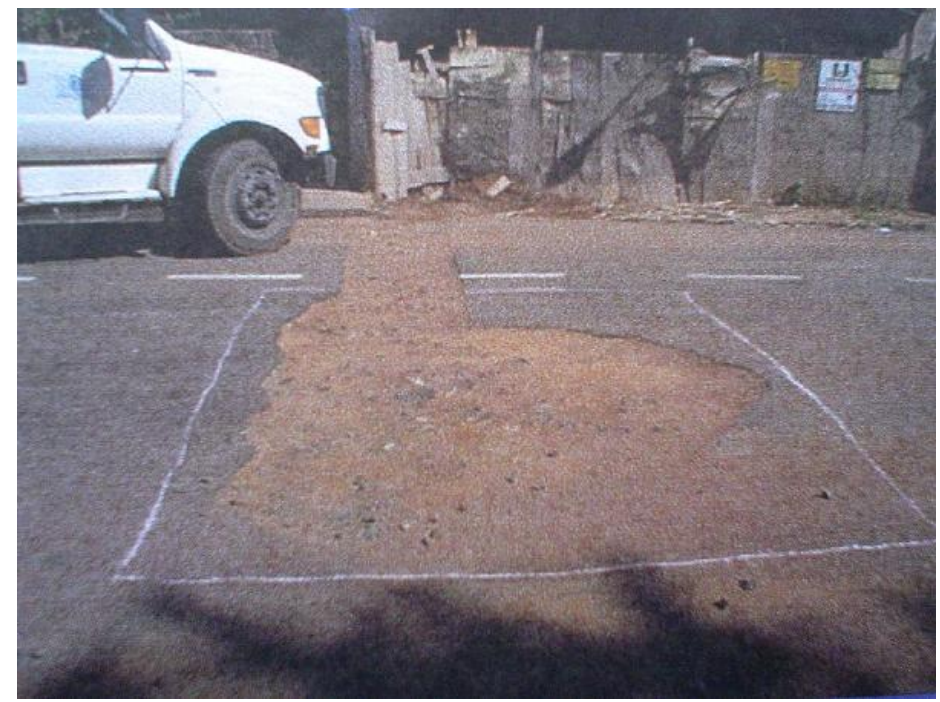

Figura 5.3 - Demarcação do corte.

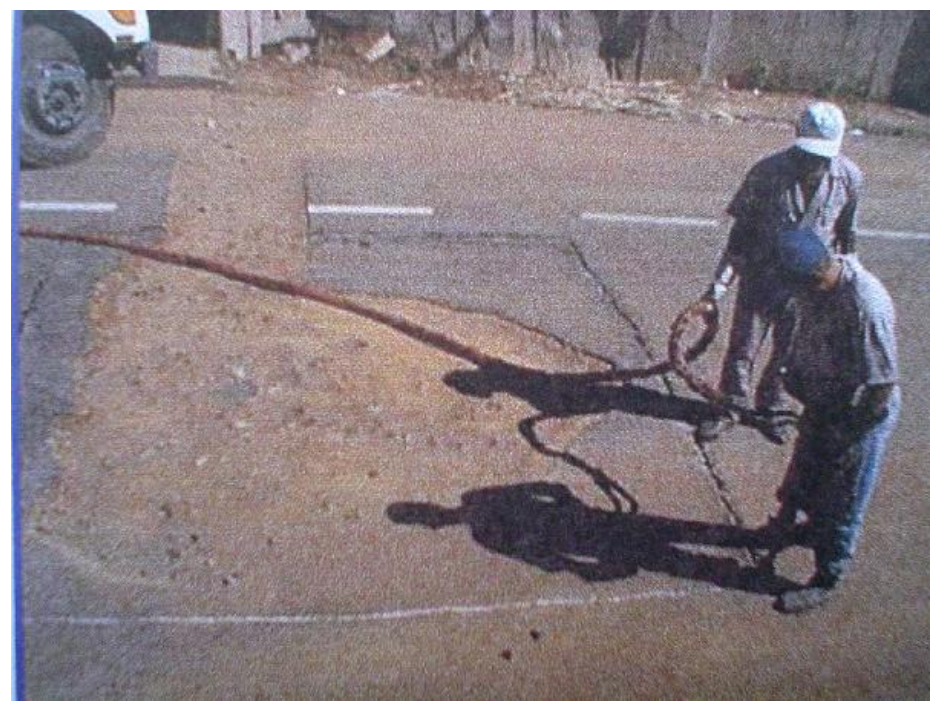

Figura 5.4 - Corte do revestimento asfáltico.

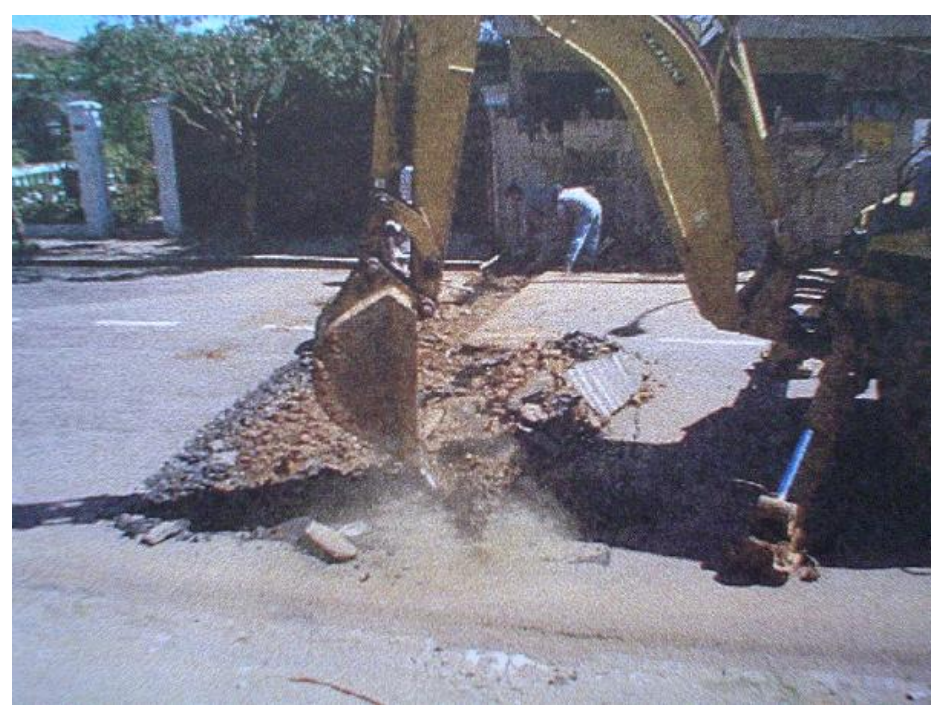

Figura 5.5 - Remoção do material existente. 


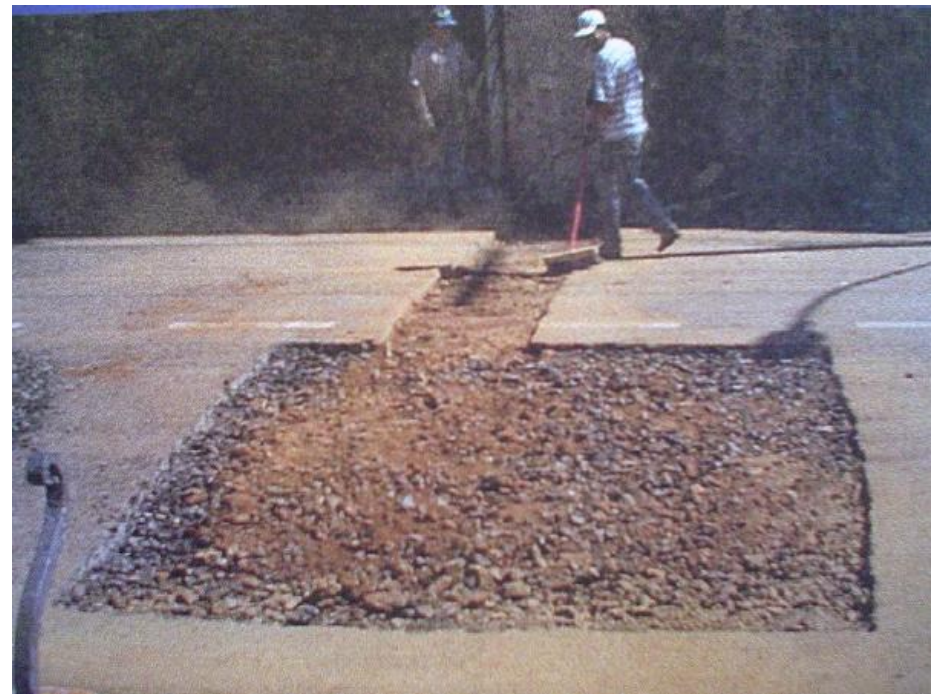

Figura 5.6 - Regularização da área.

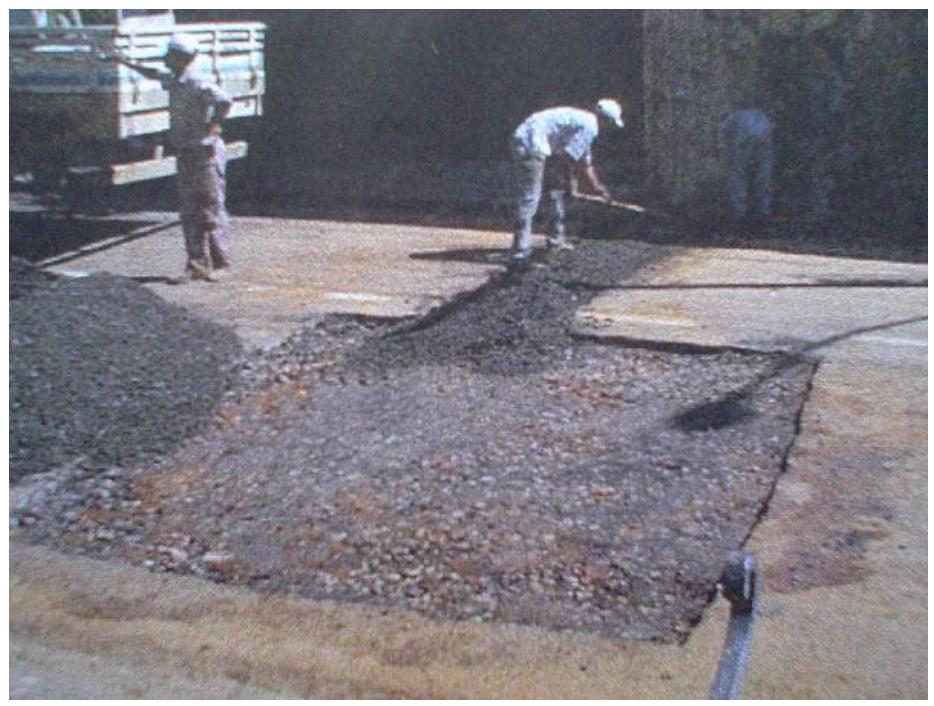

Figura 5.7 - Colocação da brita, após compactação.

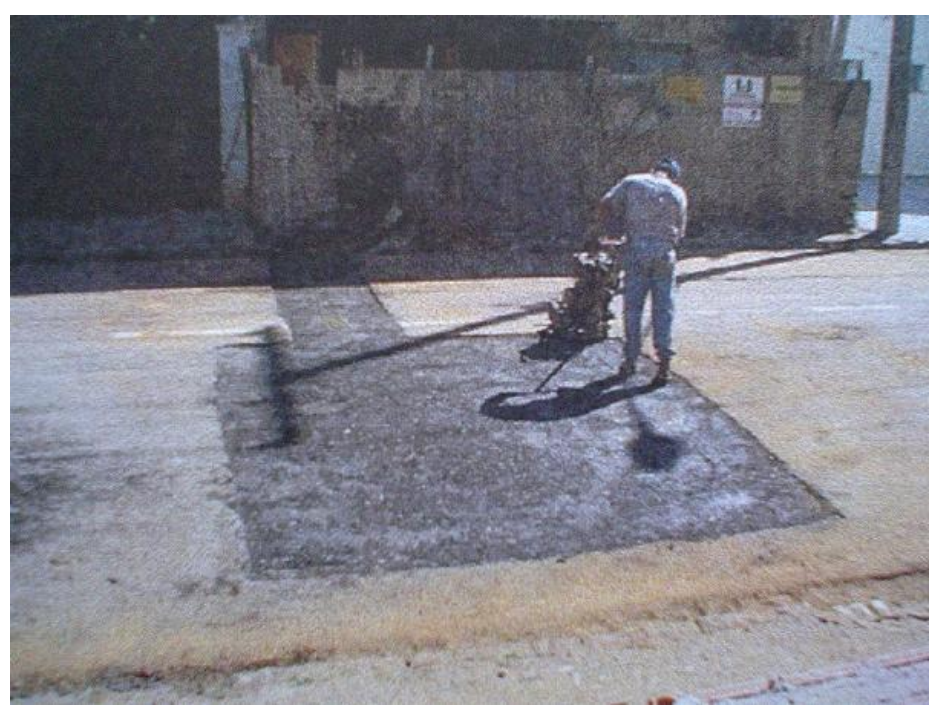

Figura 5.8 - Compactação da brita graduada. 


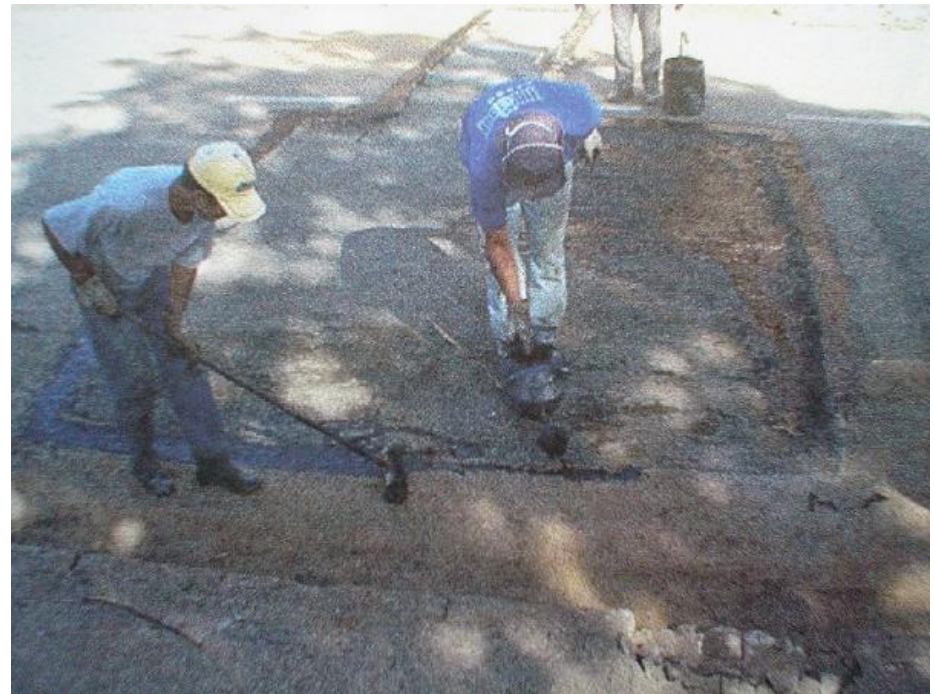

Figura 5.9 - Aplicação da pintura de ligação.

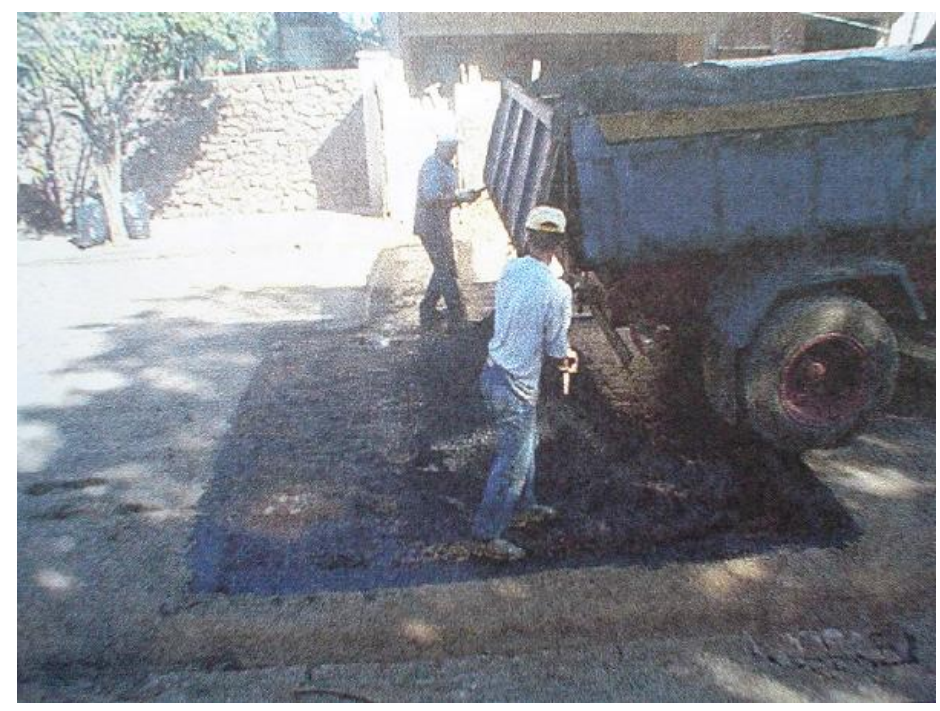

Figura 5.10 - Aplicação do revestimento.

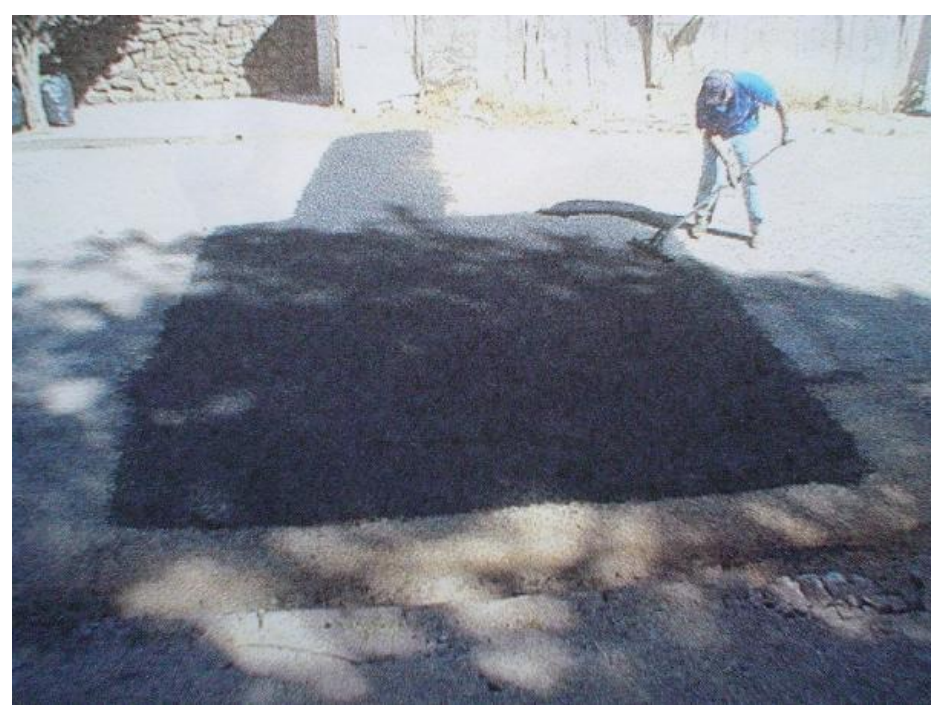

Figura 5.11 - Regularização do revestimento. 


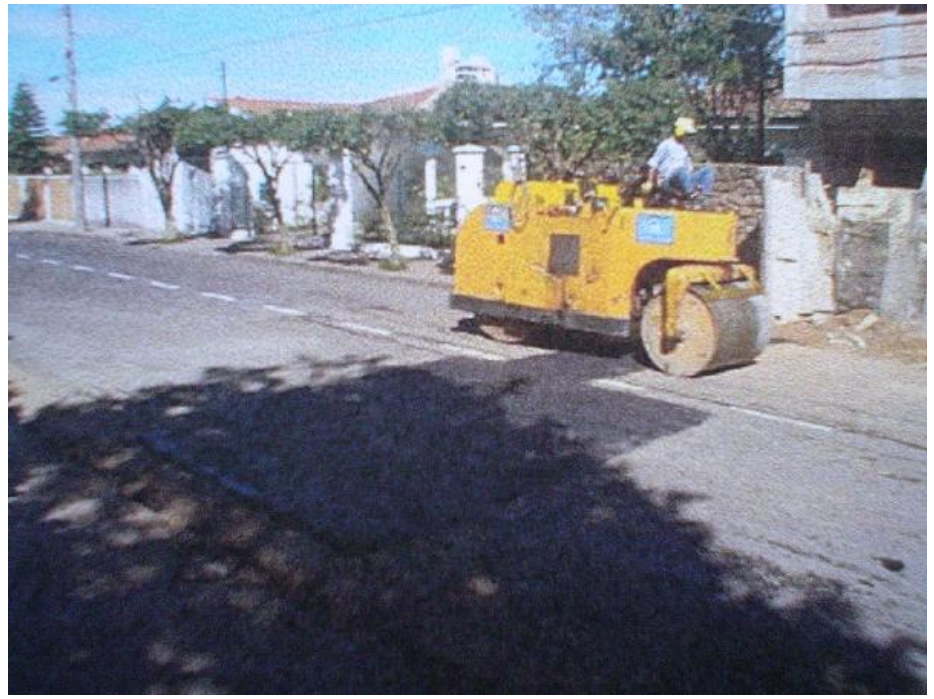

Figura 5.12 - Compactação do revestimento.

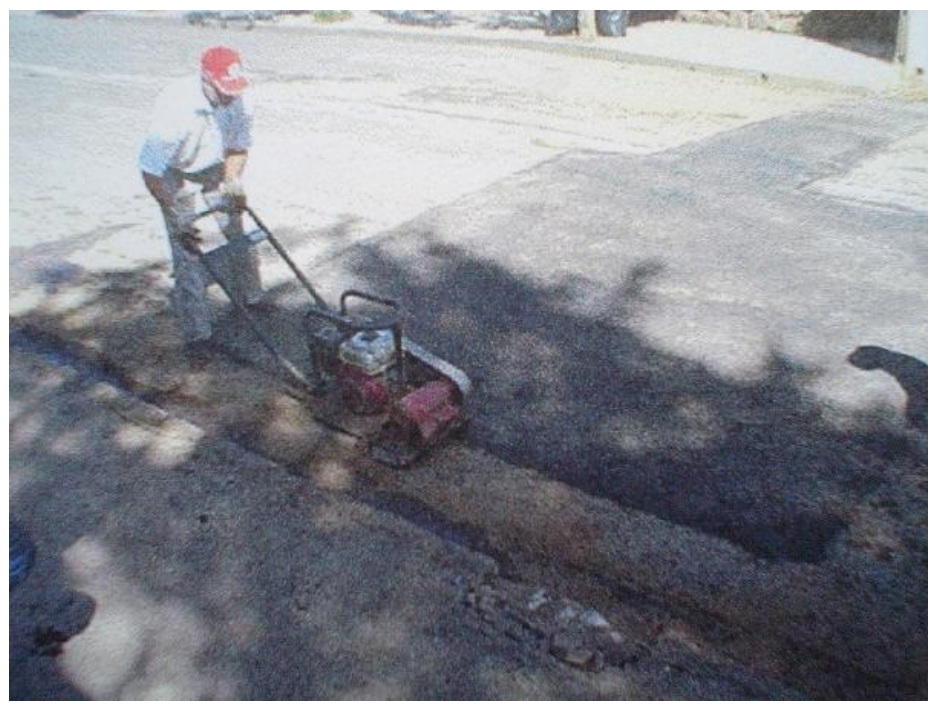

Figura 5.13 - Compactação das laterais do revestimento.

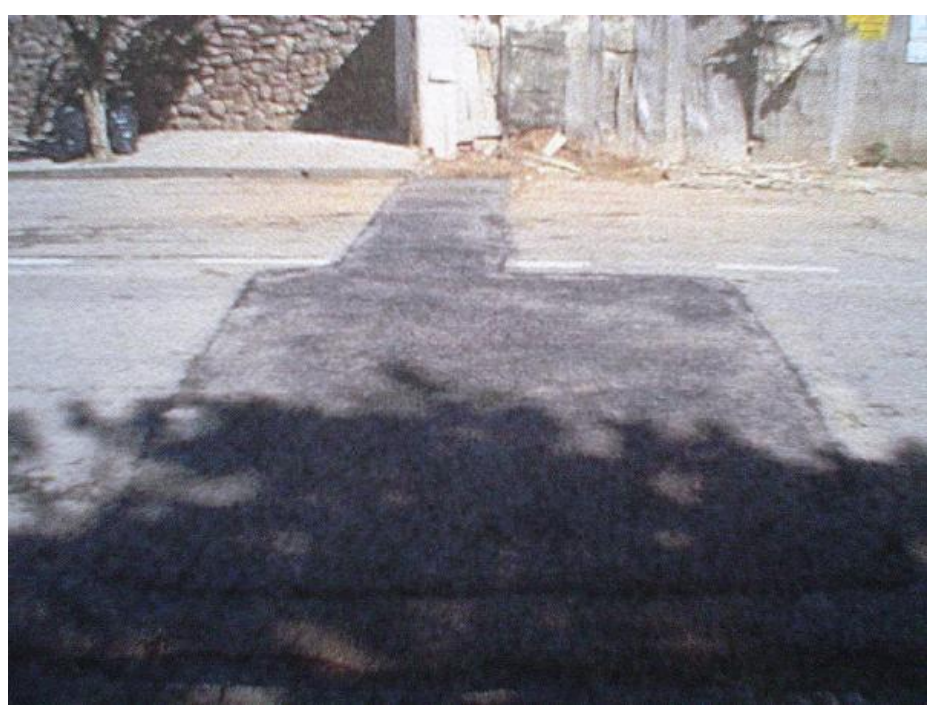

Figura 5.14 - Resultado final da execução. 


\section{3 - A CIDADE DE ARARAQUARA}

Araraquara localiza-se na região central do estado de São Paulo, a 270km da capital, na Região Sudeste do Brasil (Figura 5.1), possuindo uma área total de $1.312 \mathrm{~km}^{2}$. Tem aproximadamente 200.000 habitantes. Possui clima predominantemente tropical, com temperatura média de $31^{\circ} \mathrm{C}$, estando posicionada na latitude $21^{\circ} 47^{\prime}$ sul e longitude $48^{\circ} 10^{\prime}$ oeste (IBGE, 2000).

Notável pelo planejamento de sua área urbana, Araraquara possui grande parte de suas ruas pavimentadas. A Figura 5.15 mostra o mapa viário da cidade de Araraquara. $\mathrm{O}$ acesso aos bairros é rápido e eficiente por meio de avenidas e vias expressas. O planejamento do tráfego urbano da cidade mostrou ótimos resultados após a instalação de modernos semáforos sincronizados.

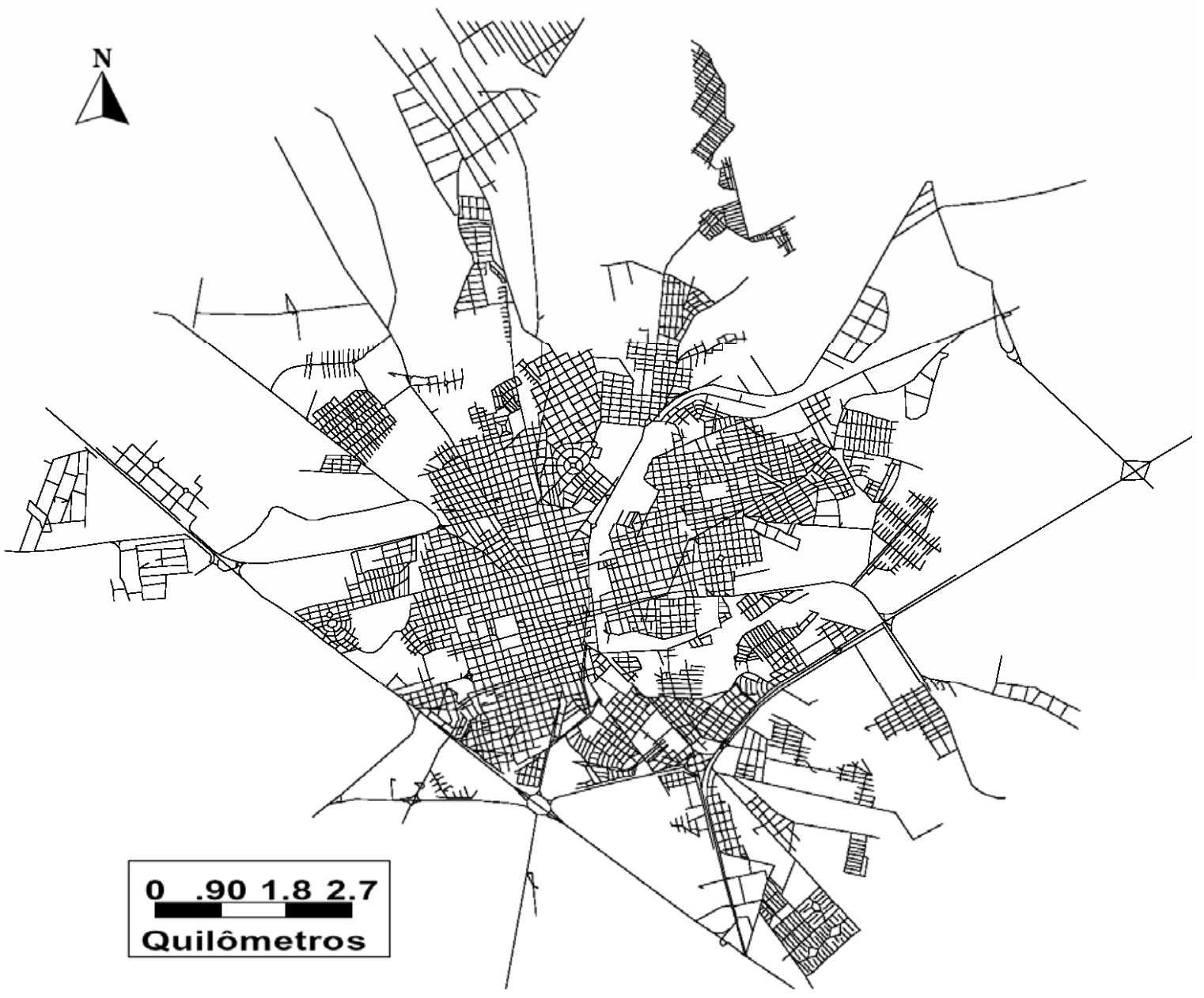

Figura 5.15- Sistema viário de Araraquara. 


\subsection{1 - Departamento AutônOMO de Água e Esgoto}

O abastecimento de água em Araraquara é realizado pelo Departamento Autônomo de Águas e Esgotos (DAAE), que atende a 100\% da população através da captação de águas superficiais e de poços profundos.

O Município é sede do Departamento de Águas e Energia Estadual (DAEE), responsável pelo atendimento a todo o Estado de São Paulo, no tocante a águas subterrâneas, sendo um referencial em pesquisa e tecnologia.

Com relação às águas subterrâneas, a localização é privilegiada, encontrando-se sobre o Aqüífero Guarani, que é o maior reservatório de água subterrânea do Mundo, que se estende por cinco Estados brasileiros e 4 países do cone Sul. É possível obter água de boa qualidade e com excelente vazão através da perfuração de poços com 350 a 450 metros. As ligações de esgoto atendem a 99\% da população.

A Estação de Tratamento de Efluentes (ETE) atende a 100\% da população, com capacidade instalada para 270 mil habitantes e projeto para 400 mil habitantes, demonstrando a preocupação e a iniciativa permanentes na preservação do meio ambiente.

Para execução de reparos de vazamentos em redes de distribuição e ramais domiciliares de água, conserto de pavimentos provenientes dos reparos, serviços complementares, em todos os setores da cidade de Araraquara, o DAAE contrata empresa especializada.

A empresa contratada deve garantir os serviços pelo prazo mínimo de 3 meses e os consertos de pavimentos por 6 meses, responsabilizando-se pelos reparos necessários nesse período, sempre que determinados pelo DAAE.

Os materiais utilizados em cada reparo são minuciosamente anotados e, semanalmente, apresenta-se uma relação de todos os que foram usados, além dos croquis de localização, endereço completo, material, diâmetro e profundidade da rede. Este procedimento além de gerar um controle dos materiais, propicia a aferição do cadastro das redes. 
Todo serviço é precedido da devida sinalização, de acordo com as normas de trânsito, utilizando-se placas de advertência, cones e fita zebrada. Quando existe necessidade de interrupção do tráfego para realização do serviço, deve-se comunicar, antecipadamente. Nas áreas centrais da cidade e nas vias de grande circulação de veículos ou de trafego de ônibus, a sinalização é reforçada, podendo requerer a programação de sua execução para o período noturno ou para os finais de semana.

O DAAE está unificando os sistemas de atendimento ao consumidor, logística, manutenção e planejamento de ações e obras, através da implantação do projeto de modernização, chamado Sistema Integrado de Planejamento, Projetos e Cadastro de Rede, com a utilização do AcquaGIS.

O AcquaGIS é o primeiro sistema de informações geográficas (SIG) desenvolvido para atender as demandas de informações das empresas de saneamento. O Sistema integra dados das várias áreas, proporcionando o apoio necessário ao desenvolvimento dos processos que envolvem a informação georreferenciada dentro das empresas de saneamento estaduais e municipais.

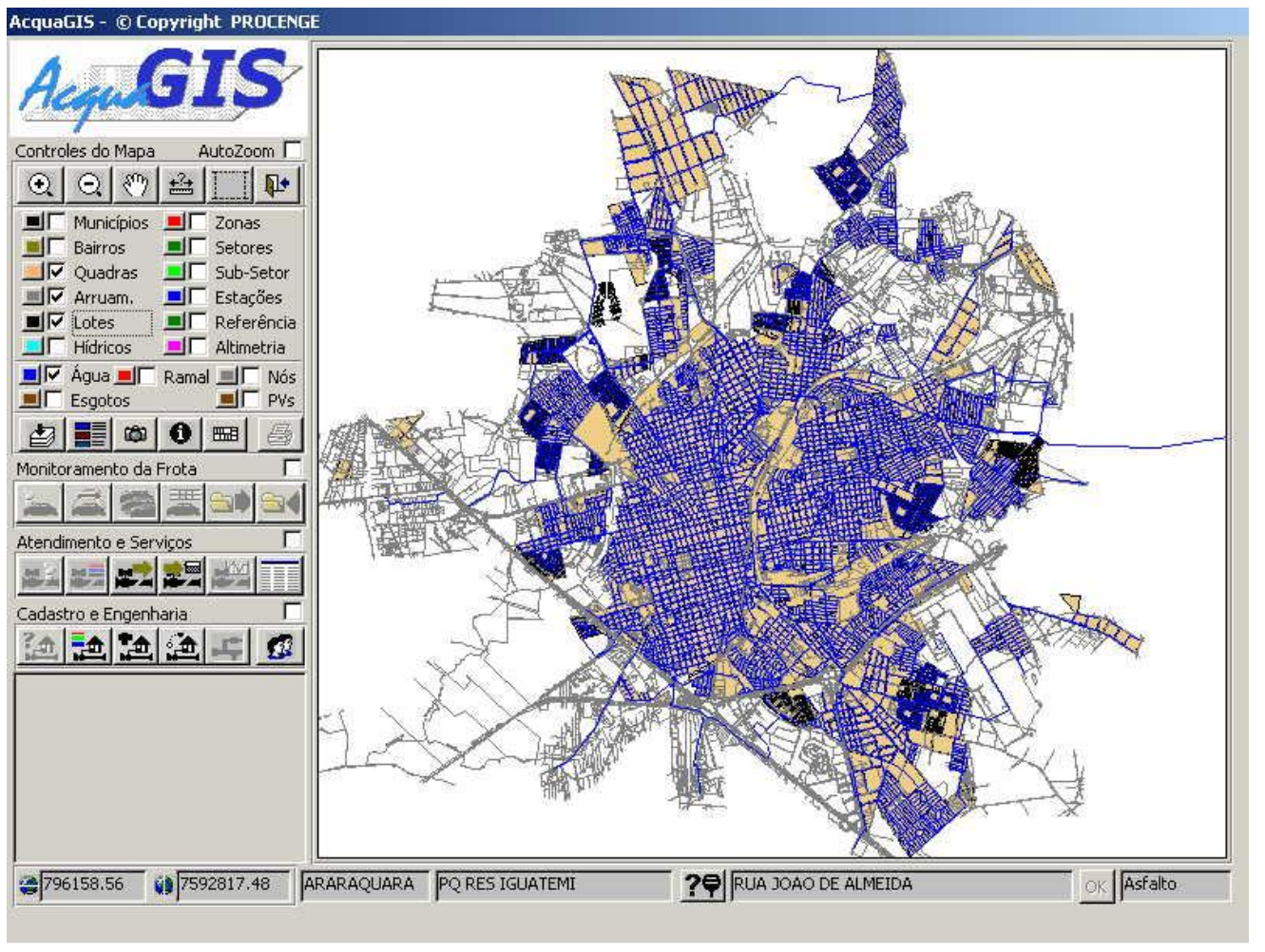

Figura 5.16 - Sistema de Informações Geográficas para Empresas de Saneamento (Geoprocessamento). 
Dentre suas principais funções podem ser destacadas:

- lançamento de redes de água e esgotos de forma estruturada e georreferenciada;

- importação de dados direto do AutoCad;

- lançamento automático das ligações de água a partir do cadastro de consumidores;

- geração automática de "overlays" (planta-quadra) sem a intervenção do desenhista (Figura 5.17);

- cadastro de nós, peças e componentes das redes armazenados no banco de dados corporativo;

- visualização dos nós da rede, com fotos das peças e ou símbolos ABNT (Figura 5.18);

- geração automática de ordens de serviço com dados do cadastro técnico e comercial (dados das redes, situação do consumidor, ruas do contorno, croqui da área);

- transmissão automática de Ordens de Serviço para a frota, via rádio ou celular GSM;

- baixa da ordem de serviço em campo, através de terminal móvel de dados;

- visualização de ortofotocartas (Figura 5.19);

- rastreio de veículos operacionais e administrativos via GPS (Figura 5.20);

- geração de mapas temáticos em tempo real:

- Serviços em execução (por tipo, por equipe);

- Serviços concluídos;

- Serviços programados;

- Veículos ociosos (localização e status);

- Situação de consumidores (cortados, lidos, média, pendências);

- Situação de hidrômetros (idade, número de ocorrências, classe);

- Mapa de Consumidores por Classe (tipo);

- Mapa de Consumo Médio ou Absoluto;

- Mapa de Cadastro de Rede (por material, por idade, por diâmetro); 
- visualização da localização do consumidor e redes disponíveis;

- visualização dos dados de consumo e pendências de um consumidor, a partir da localização no mapa (Figura 5.21);

- zoom-in, zoom-out, pan e medição de distâncias diretamente no mapa digital;

- interface com layers selecionáveis pelo usuário (município, bairro, setor, quadras, logradouros, redes).

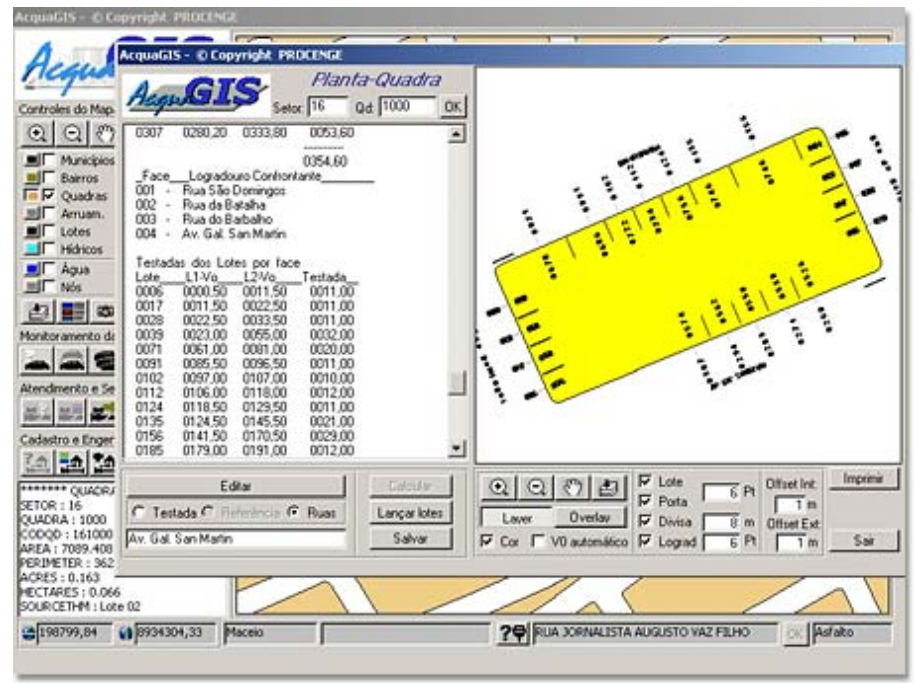

Figura 5.17 - Geração automática de Overlays (planta-quadra).

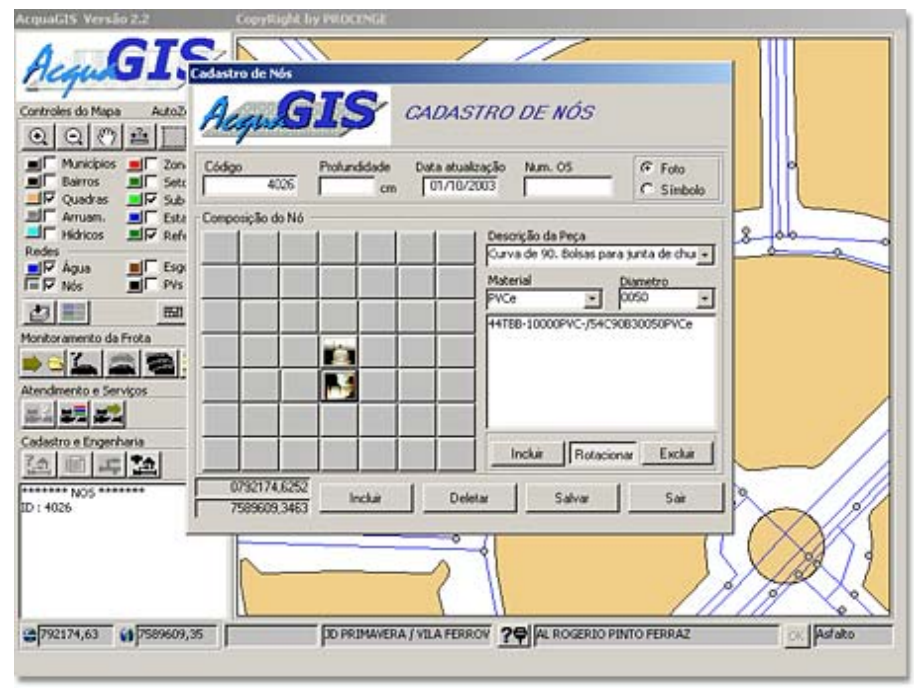

Figura 5.18 - Nós de rede com fotos das peças e ou símbolos ABNT. 


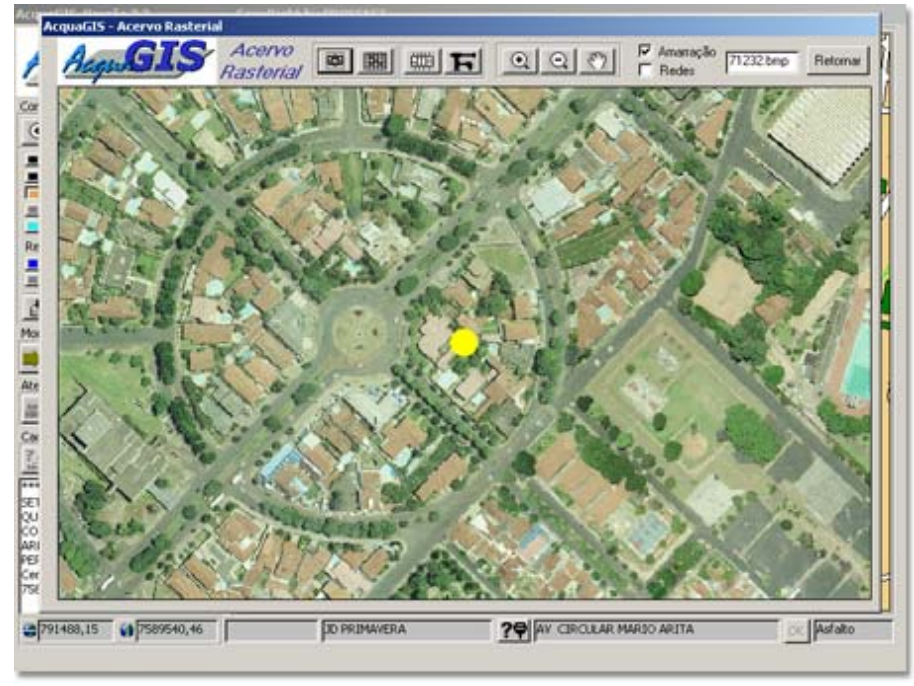

Figura 5.19 - Visualização de ortofotocartas.

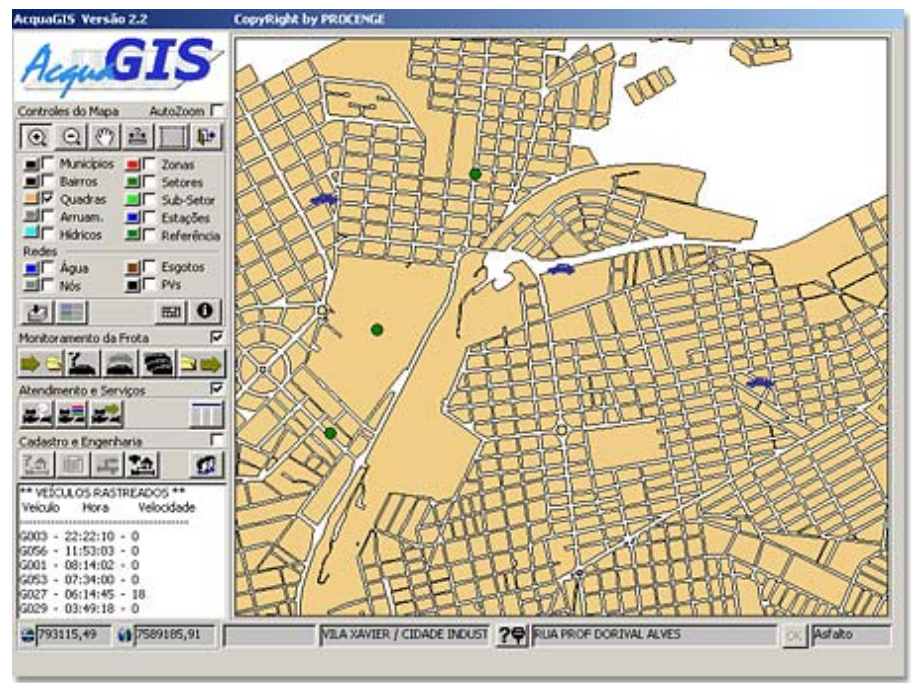

Figura 5.20 - Rastreio de veículos operacionais e administrativos via GPS.

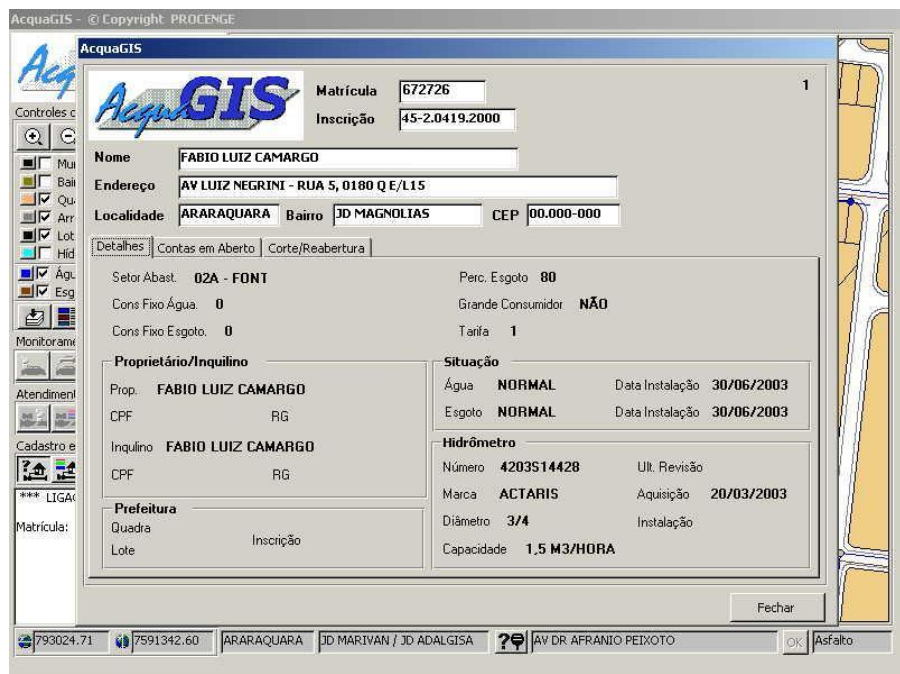

Figura 5.21 - Visualização dos dados de consumo e pendências de um consumidor a partir da localização no mapa. 
Atualmente, todas as viaturas possuem um computador de bordo e uma antena satélite, pelos quais as indicações de serviço são passadas. Através de um cadastro digital, o funcionário do DAAE pode encontrar o veículo que está mais próximo do local da ocorrência e saber se ele está disponível e com material suficiente e adequado.

Anteriormente, o funcionário chegava ao local sem saber o tipo de tubulação e medida que iria encontrar, nem mesmo a que distância da calçada a rede seria encontrada. Dessa forma o trabalho é agilizado, tornando-se mais eficiente.

A integração com dados de rastreio (GPS) de frotas e leituristas e a comunicação remota de dados completam o sistema, que conta com equipamentos específicos fornecidos junto com o software.

Com relação à alimentação dos dados cadastrais referentes à cidade de Araraquara, encontra-se em fase avançada. Os dados dos bairros encontramse praticamente $100 \%$ cadastrados, sendo que as quadras e ruas estão totalmente atualizadas pela Prefeitura Municipal. As redes de água estão 100\% cadastradas e em fase de revisão. Quanto ao esgoto, 30\% das redes já encontram-se digitalizadas.

\subsection{2 - COLETA DOS DADOS - DAAE ARARAQUARA}

Segundo procedimento fixado pelo DAAE, a empresa contratada deve estar atenta para as possíveis interferências junto a CPFL, Telefônica, DAAE, Prefeitura Municipal de Araraquara (PMA) e empresa de distribuição de gás natural, pois a inobservância das referidas interferências acarreta sanção para a empresa contratada.

A abertura da vala deve ser feita atendendo-se às condições da NR 18, aprovadas pela Portaria 3214. Deve-se fazer a sondagem do terreno para que não haja rompimento das interferências, anteriormente constatadas. O local deve estar isento de vegetação e detritos. 
Ocorrendo o corte do asfalto, o descarte do pavimento removido é feito de maneira que não entre em contato com a água retirada da vala através da bomba de sucção, evitando assim fazer sujeira além do necessário. O material retirado (solo) não pode ser reaproveitado.

Após a abertura da vala e a execução do reparo, deve-se remover o barro, inclusive das paredes laterais e do fundo da vala, sendo desta forma providenciado o reaterro, devidamente compactado, deixando o local o mais limpo possível. Nas valas ou buracos de pequenas dimensões, em que não é possível a compactação mecânica, deve-se utilizar o soquete manual.

Acima da tubulação, é depositada uma camada de solo de aproximadamente $50 \mathrm{~cm}$, sendo compactado com equipamento mecânico tipo "sapo". Prossegue-se o aterro em camadas de 20 a $30 \mathrm{~cm}$, mantendo-se a compactação até a superfície do terreno. O DAAE não permite o uso de retroescavadeira para compactação da última camada.

Cada camada deve ser compactada com no mínimo 3 "passagens" do compactador. A compactação deve ser realizada com solo na umidade adequada, próxima ao teor ótimo. Se necessário, pode-se molhar com carro pipa ou equivalente.

Com a remoção da terra junto à borda do pavimento onde foi realizado o corte, coloca-se uma camada de 8 a $10 \mathrm{~cm}$ de brita $\mathrm{n}^{\circ} 3$ e compacta-se com equipamento tipo "sapo". Posteriormente, coloca-se o pó de pedra sobre a brita, sendo o mesmo espalhado com escovão, até o total travamento. A compactação é feita novamente. Procedida a imprimadura em toda a extensão da vala, com utilização de emulsão asfáltica de ruptura rápida, tipo RR-1C, 0 acabamento é feito com 3 a $4 \mathrm{~cm}$ de concreto betuminoso usinado a quente (CBUQ), classificação DER tipo "D". Todo reparo de pavimento deverá ser precedido da regularização das bordas laterais, utilizando ferramentas manuais, tornando-as regulares com ângulo de $90^{\circ}$.

Nas áreas centrais da cidade e nas vias de grande circulação de veículos ou de tráfego de ônibus, não se dispondo de CBUQ, mediante autorização da fiscalização do DAAE, a contratada deverá executar o reparo do 
pavimento com asfalto misturado a frio, seguindo as características de preparação descritas no item acima.

Os consertos em paralelepípedos, blocos de concreto, guias, sarjetas e calçadas, quando a rede passar sob a mesma, são executados pelo DAAE.

Todas as valas e buracos devem ser aterrados no mesmo dia, devidamente compactados. O empedramento e a imprimadura das valas são executados dentro de no máximo 1 dia útil após a conclusão do reparo dos vazamentos. Os reparos nos pavimentos com CBUQ devem ser executados em 5 dias úteis, a contar da data de conclusão do vazamento. Os reconsertos, depois de comunicado pela fiscalização, têm prazo de 5 dias para serem executados, ficando a empresa obrigada a refazer tantas vezes quantas forem necessárias, até que o serviço fique de acordo com as especificações exigidas.

São considerados reconsertos os reparos de pavimentos reprovados pela fiscalização do DAAE, pelo motivo de estar abaixo ou acima do greide da rua, ou devido à ocorrência de "borrachudo" provocado por umidade ou em condição insatisfatória. Tais reconsertos são executados removendo-se todo o asfalto anterior, até atingir a base de brita. Refaz-se a compactação mecanicamente, aplicando novo acabamento com CBUQ. Quando o reparo se encontra na área central ou em vias de grande circulação, deve ser executado no mesmo dia e, se necessário, utilizando massa fria.

\section{4 - ANÁLISE dOS DADOS}

Com o intuito de facilitar o entendimento, a análise dos dados é apresentada separadamente. Primeiramente, em nível de rede, sendo avaliadas as possibilidades de compatibilização da gerência de pavimentos com a gerência de outras infra-estruturas urbanas.

Em seguida, em nível de projeto, fazendo-se uma análise das normas de execução dos serviços, dos métodos de execução efetivamente utilizados e dos critérios de recebimento dos serviços. 


\subsection{1 - NíVEL DE REDE}

Considerando que a interface de um SIG com uma planilha eletrônica simplifica a entrada de dados, iniciou-se a digitação das 5.353 solicitações de ligações executadas pelo SAAE São Carlos no período de 2002 a 2004, com o intuito de integrar o sistema de gerência das atividades de infra-estruturas de água e esgoto com o Sistema de Gerência de Pavimentos Urbanos (SGPU), estudado por Zanchetta (2005).

Esses dados foram organizados a partir da listagem diária das ligações executadas (Figura 5.22), onde se destacavam as seguintes informações: data, nome da rua, número da casa, setor, quadra, posição da rede, solicitação e, principalmente, se são executadas com ou sem corte do pavimento asfáltico.

Como a ordem de serviço chega ao funcionário do SAAE já com os campos de endereço (nome da rua e número), setor e quadra devidamente preenchidos, cabe apenas atestar no local o posicionamento da rede (se com corte no asfalto longo ou curto, se na terra ou calçada) e a solicitação prestada (ligação de água, esgoto ou ambas, ou mudança de água, esgoto ou ambas).

\begin{tabular}{|c|c|c|c|c|c|c|}
\hline \multicolumn{7}{|c|}{ S.M.R. - DOS } \\
\hline \multicolumn{7}{|c|}{ RELAÇÃO DAS LIGAÇÕES EXECUTADAS NO DIA 15/12/2004 } \\
\hline \multicolumn{7}{|c|}{ COM CORTE ASFÁLTICO } \\
\hline PL.NÚMERO & ENDEREÇO & N. & Setor & Qd. & Pos.rede & Solicitação \\
\hline 36382 & Rua Francisco Pelegrini & 170 & 15 & 1 & curto & LIG. AG/ESG \\
\hline 36732 & Rua Luiz Rodrigues Sampaio & 164 & 12 & 345 & longo & LIG. AG \\
\hline 37622 & Rua Quinze de Nevembro & 2011 & 2 & 102 & curto & MUD. AG \\
\hline \multicolumn{7}{|c|}{ SEM CORTE ASFÁLTICO } \\
\hline PL.NÚMERO & ENDEREÇO & N. & Setor & Qd. & Pos.rede & Solicitação \\
\hline 36949 & Rua Sophia Bagnato & 192 & 5 & 260 & terra & LIG. AG/ESG \\
\hline 37082 & Rua Aldo Germano Klein & 42 & 5 & 252 & terra & LIG. AG/ESG \\
\hline 37580 & Rua Peru & 466 & 14 & & calçada & LIG. AG \\
\hline
\end{tabular}

Figura 5.22 - Informações constantes da lista de execução diária de ordens de serviços (SAAE). 
Inicialmente, alguns pontos importantes puderam ser observados (Tabelas 5.4 e 5.5). Dentre todas as solicitações, a ligação de água simultânea com a de esgoto representa 51,9\% do total das ligações. Dentre essas, 32,1\% do total são executadas sem corte asfáltico, que correspondem, principalmente, à obrigatoriedade de se deixar, nos novos loteamentos, uma espera de esgoto e água em cada lote, para a execução das ligações sem causar danos ao pavimento. Mesmo assim, com a falta de planejamento nos loteamentos antigos 19,8\% do total das solicitações acabam ocasionando corte no pavimento asfáltico.

As solicitações de mudança de água também são significativas. Com $29,9 \%$ do total de solicitações, apenas 3,1\% desses não ocasionam corte asfáltico. Esses $26,8 \%$ de solicitações com corte asfáltico surgem, principalmente, por vazamento nas ligações antigas, devido à deterioração dos tubos galvanizados, que exigem a substituição por tubo em PEAD.

Tabela 5.4 - Ligações executadas pelo SAAE (2002-2004).

\begin{tabular}{lccccc}
\hline \multirow{2}{*}{ SOLICITAÇÃO } & \multicolumn{2}{c}{ COM CORTE ASFÁLTICO } & \multicolumn{2}{c}{ SEM CORTE ASFÁLTICO } & \multirow{2}{*}{ TOTAL } \\
\cline { 2 - 5 } & LONGO & CURTO & CALÇADA & TERRA & \\
\hline MUD. ÁGUA & $\mathbf{7 4 7}$ & $\mathbf{6 9 3}$ & 153 & 10 & $\mathbf{1 6 0 3}$ \\
MUD. ESGOTO & 29 & 70 & 22 & 11 & 132 \\
MUD. ÁG/ESG & 46 & 50 & 9 & 0 & 105 \\
LIG. ÁGUA & 162 & 150 & 262 & 35 & 609 \\
LIG. ESGOTO & 30 & 53 & 32 & 11 & 126 \\
LIG. ÁG/ESG & $\mathbf{5 9 2}$ & $\mathbf{4 7 1}$ & $\mathbf{1 5 8 3}$ & 132 & $\mathbf{2 7 7 8}$ \\
\hline TOTAL & 1606 & 1487 & 2061 & 199 & 5353 \\
\hline
\end{tabular}

Tabela 5.5 - Porcentagem de ligações executadas pelo SAAE (2002-2004).

\begin{tabular}{lccccc}
\hline \multirow{2}{*}{ SOLICITAÇÃO } & \multicolumn{2}{c}{ COM CORTE ASFÁLTICO } & \multicolumn{2}{c}{ SEM CORTE ASFÁLTICO } & \multirow{2}{*}{ TOTAL } \\
\cline { 2 - 4 } & LONGO & CURTO & CALÇADA & TERRA & \\
\hline MUD. ÁGUA & $\mathbf{1 3 , 9 \%}$ & $\mathbf{1 2 , 9} \%$ & $2,9 \%$ & $0,2 \%$ & $\mathbf{2 9 , 9 \%}$ \\
MUD. ESGOTO & $0,5 \%$ & $1,3 \%$ & $0,4 \%$ & $0,2 \%$ & $2,4 \%$ \\
MUD. ÁG/ESG & $0,9 \%$ & $0,9 \%$ & $0,2 \%$ & $0,0 \%$ & $2,0 \%$ \\
LIG. ÁGUA & $3,0 \%$ & $2,8 \%$ & $4,9 \%$ & $0,7 \%$ & $11,4 \%$ \\
LIG. ESGOTO & $0,6 \%$ & $1,0 \%$ & $0,6 \%$ & $0,2 \%$ & $2,4 \%$ \\
LIG. ÁG/ESG & $\mathbf{1 1 , 0} \%$ & $\mathbf{8 , 8} \%$ & $\mathbf{2 9 , 6} \%$ & $2,5 \%$ & $\mathbf{5 1 , 9 \%}$ \\
\hline TOTAL & $29,9 \%$ & $\mathbf{2 7 , 7} \%$ & $38,6 \%$ & $3,8 \%$ & $100,0 \%$ \\
\hline
\end{tabular}


Em síntese, pode-se notar, na Figura 5.23, que ainda existe um grande número de solicitações executadas com corte asfáltico (57,6\%). Dessa forma, é necessário salientar, mais um vez, que as infra-estruturas básicas, como redes de água e esgoto devem ser implantadas antes da execução dos serviços de pavimentação asfáltica, evitando-se, assim, o excesso de remendos desnecessários em ruas recém pavimentadas.

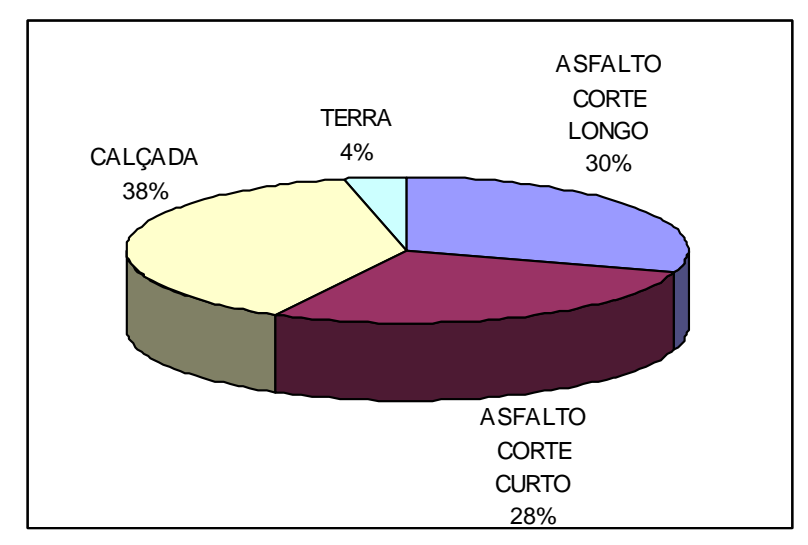

Figura 5.23 - Localização das ligações do SAAE (2002-2004).

$\mathrm{Na}$ organização dos dados que seriam transferidos para o SIG, com a intenção de compatibilizar a gerência de pavimentos com a gerência de infraestrutura de água e esgoto, alguns problemas foram identificados. A grande maioria das solicitações estava com a informação das localizações (setor e quadra) desencontradas, sendo que, em muitos casos, os setores, quadras e endereços das ruas não combinavam. Ao investigar esse problema, identificouse que o erro surgiu no preenchimento da liberação da ordem de serviço, sendo assim tornou-se totalmente inviável a transferência desses dados para análise no SIG, considerando que a posição dos serviços é o dado de maior importância dentro de um sistema de informação geográfica.

Em contrapartida, como descrito anteriormente, o DAAE Araraquara utiliza atualmente o AcquaGIS, que é um sistema de informações geográficas (SIG) que integra dados das várias áreas, proporcionando o apoio necessário ao desenvolvimento dos processos que envolvem a informação georreferenciada dentro das empresas de saneamento. 


\subsection{2 - Nível DE PROJETO}

Tanto o SAAE São Carlos como o DAAE Araraquara, atualmente, não seguem nenhuma norma específica de execução dos serviços, mas ambos planejam a elaboração dessas instruções internas. O SAAE não possui nenhum plano atual para essa implementação, em contrapartida o DAAE encontra-se em uma fase avançada de preparação desse material, sendo que cada um de seus departamentos está definindo diretrizes e especificações técnicas necessárias para elaboração desses normativos.

Com o intuito de atingir esse objetivo, pode-se considerar como um caso bem sucedido a elaboração dos normativos ocorrida na Secretaria de Infra-Estrutura Urbana (SIURB) da Prefeitura Municipal de São Paulo (PMSP). A partir da análise de materiais pré-existentes, normas antigas, novas diretrizes e instruções de projeto, o Grupo de Trabalho instituído pela portaria 248/SIURB/2002 organizou normas relativas à pavimentação urbana.

A função das Instruções, Normas e Manuais Técnicos nas atividades da Divisão de Projetos de Pavimentação e Divisão de Obras de Pavimentação da Secretaria de Infra-Estrutura Urbana da Prefeitura Municipal de São Paulo é de orientar as fases de projeto, construção e conservação das Vias Públicas, quer sejam executados pela própria Secretaria, quer por outros órgãos da Prefeitura Municipal de São Paulo (PMSP), ou mesmo por particulares, a fim de garantir a qualidade dos serviços.

Esse objetivo é alcançado através da definição de diretrizes e requisitos técnicos na elaboração de projetos, execução e conservação das obras de pavimentação. Como apoio às atividades de Fiscalização, as normas e manuais técnicos devem ser periodicamente revistos e atualizados, para incorporar a evolução tecnológica no projeto e construção.

São apresentadas, nos Anexos A, B e C as Instruções de Reparação da PMSP para Pavimentos Flexíveis (IR-01), Pavimentos de Concreto (IR-02) e Pavimentos Articulados (IR-03) danificados por Abertura de Valas. Essas Instruções têm como objetivo fixar o modo pelo qual se executa a reparação de pavimentos danificados em decorrência da abertura de valas na via pública. 
Apesar de não possuírem suas normas, tanto no SAAE São Carlos como no DAAE Araraquara os serviços são executados obedecendo algumas especificações descritas nos editais de contratação das empresas terceirizadas.

Embora o SAAE apresente o serviço de reposição asfáltica de uma forma contínua, não é exatamente o que ocorre. Primeiramente, compete ao SAAE a abertura da vala, execução dos serviços de água e esgoto e o seu aterramento. Em seguida, cabe à empresa contratada efetuar a restauração asfáltica, sendo que esse serviço é dividido em duas etapas.

Levando-se em consideração os métodos de execução efetivamente utilizados, o fechamento da vala é feito de forma descuidada. Apesar de serem aterradas no mesmo dia, todas as valas e buracos geralmente não são devidamente compactados e, na maioria das vezes o solo saturado das paredes laterais e do fundo da vala não é removido. Dessa forma, a qualidade final do pavimento reconstituído é diretamente afetada, originando recalque devido ao adensamento do solo de reaterro (Figura 5.24).

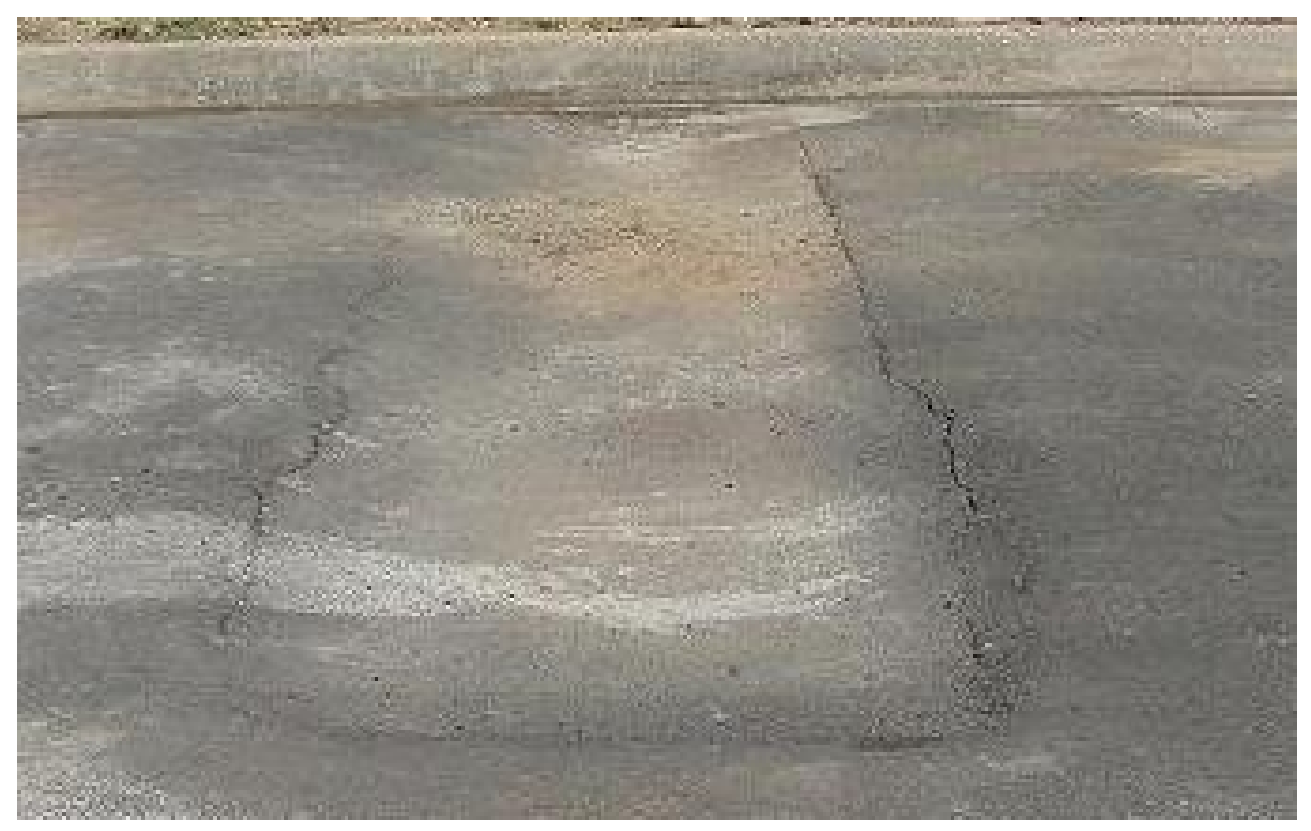

Figura 5.24- Recalque do pavimento reconstituído. 
Por não haver nenhuma obrigatoriedade de tempo máximo de execução do reparo, existe uma grande demora entre o reaterro e o início da execução da base. São muito freqüentes os casos em que valas ficam abertas por um período maior que 30 dias. Esse atraso, além de causar deterioração do pavimento próximo à vala (Figura 5.25), gera um grande transtorno aos que utilizam a via, além de significar risco para o usuário.

É observada, também, uma demora entre a execução da base e a aplicação da camada de rolamento. Devido ao contato direto com o tráfego, freqüentemente, se faz necessário o melhoramento da base de brita graduada anteriormente à aplicação da imprimadura de ligação.

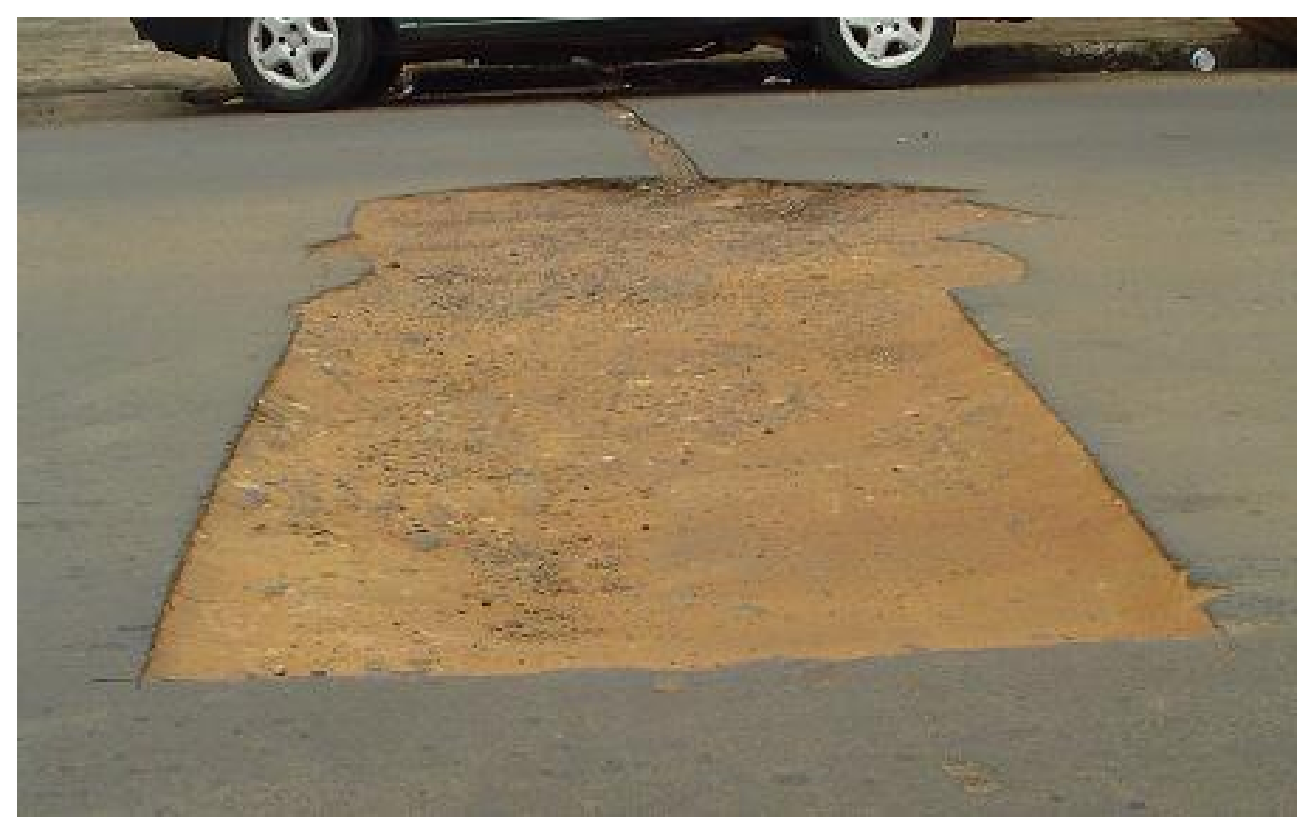

Figura 5.25 - Deterioração das áreas do pavimento próximo à vala.

Um ponto a ser destacado é que o DAAE Araraquara estabelece prazos rigorosos para os intervalos de execução dos reparos de vazamentos, das ligações, dos tapa buracos e, principalmente, dos consertos de pavimentos. Esses prazos acabam proporcionando um grau de desconforto praticamente imperceptível aos usuários das vias públicas, pois dessa forma as valas acabam permanecendo abertas por um período muito curto. $\mathrm{O}$ descumprimento desses prazos acaba acarretando à contratada uma multa para cada serviço. 
Considerando-se os critérios de recebimento dos serviços, a fiscalização do DAAE analisa se o remendo coincide com greide da rua, ou se ocorre algum indício de "borrachudo" provocado por umidade. Caso exista alguma condição insatisfatória, tais reconsertos são executados, removendo-se todo o asfalto anterior, até atingir a base de brita. O índice de reconserto (IR) aceito é de apenas $10 \%$ do total de serviços executados. Caso o número venha a ultrapassar esse limite, a Contratada sofre uma multa para cada serviço que for necessário executar o reconserto.

Cabe ao fiscal do SAAE São Carlos avaliar apenas o recebimento final dos serviços, dessa forma, apenas a capa de rolamento é avaliada. Caso exista algum erro de execução no subleito ou mesmo na base, inicialmente não é observado, pois geralmente aparecem com o tempo. O único caso de reconcerto considerado é na condição em que o remendo encontra-se abaixo do greide da rua, sendo exigida apenas a complementação da capa. 


\section{6 - Conclusões E Sugestões PARA TrabalHos FUTUROS}

\section{$6.1-$ CONCLUSÕES}

Este trabalho analisou os problemas de pavimentação urbana causados por intervenções dos sistemas de infra-estrutura, através do estudo de caso nas cidades paulistas de São Carlos e Araraquara. Foram estudadas basicamente, as interferências de obras de serviço de água e esgoto sobre o desempenho de pavimentos urbanos. Avaliaram-se os serviços executados pelo SAAE em São Carlos e pelo DAAE em Araraquara. Em nível de rede, foram analisadas as possibilidades de compatibilizar a gerência de pavimentos com a gerência de outras infra-estruturas urbanas. E, em nível de projeto, as normas de execução dos serviços, os métodos de execução efetivamente utilizados e os critérios de recebimento dos serviços.

Na maioria das cidades do Estado de São Paulo e também do Brasil verifica-se a inexistência de sistemas racionais para o gerenciamento das infraestruturas públicas (pavimento, água, esgoto, energia elétrica, telefone, gás). Além da inexistência desses sistemas dentro das prefeituras e concessionárias de serviços públicos, outro problema que se pode destacar é a falta de comunicação entre os setores de administração pública municipal, os quais fazem uso de uma forma independente do espaço físico da malha viária. 
Não se deve esperar por um momento ideal para a implantação de um sistema de gerência, seja de pavimento ou de qualquer outra infra-estrutura urbana. Deve-se destacar que é possível começar a qualquer hora, sendo que o primeiro passo consiste na obtenção de apoio administrativo, o que não é uma tarefa fácil, pois, de início, ninguém se sente confortável com mudanças, e a implementação de um sistema de gerência requer alterações na maneira como os profissionais pensam, reagem e executam seu trabalho diário.

Grande parte dos remendos nos pavimentos é causada pelas concessionárias de serviço de água e esgoto, sendo assim, indispensável a compatibilização da gerência de pavimentos com a gerência de outras infraestruturas urbanas. A integração desses sistemas poderá ser facilitada com a utilização de Sistemas de Informação Geográfica (SIG). Mas não devem ser utilizados somente como um banco de dados e sim para transformar dados em informações, processando-os, executando análises e realizando simulações. Quanto mais informação disponível, melhores as previsões da condição futura, sendo assim maiores as chances de acerto nas decisões tomadas pela gerência em nível de rede.

Compete às prefeituras e concessionárias de serviços públicos a elaboração de instruções, normas ou manuais, definindo diretrizes e requisitos técnicos necessários para execução e conservação das obras de pavimentação, sendo que os mesmos devem, periodicamente, ser revistos e atualizados, para incorporar a evolução tecnológica no projeto e construção.

É indispensável que haja, além de tudo, um controle mais rigoroso por parte da fiscalização, quando da execução das obras de reposição asfáltica no fechamento das valas. Tais exigências proporcionam uma maior qualidade de execução e, conseqüentemente, uma maior durabilidade dos serviços, não gerando gastos de manutenção e reabilitação antes do tempo previsto. 


\section{2 - SugESTÕES PARA TRABALHOS FutUROS}

Como sugestões para o desenvolvimento de trabalhos complementares, pode-se destacar:

- dar continuidade à compatibilização da gerência de pavimentos com a gerência de infra-estrutura de água e esgoto;

- estender as análises do estudo piloto desenvolvido neste trabalho (infraestrutura de água e esgoto) a outras infra-estruturas urbanas (energia elétrica, gás, telefonia);

- estudar formas não destrutivas de se instalar as infra-estruturas urbanas;

- avaliar a evolução da condição das intervenções ao longo do tempo, levando-se em consideração os custos envolvidos;

- analisar os problemas (patologias) mais freqüentemente identificados nas reposições de valas e estudar suas causas. 


\section{REFERÊNCIAS BIBLIOGRÁFICAS}

ABES (1978). Manual do instalador de redes públicas de água. Vol.1: Abertura e fechamento de valas. Associação Brasileira de Engenharia Sanitária e Ambiental. Rio de Janeiro, RJ.

ABES (1979a). Manual do instalador de ramais prediais de água. Vol.1: Abertura e fechamento de valas. Associação Brasileira de Engenharia Sanitária e Ambiental. Rio de Janeiro, RJ.

ABES (1979b). Manual do instalador de redes de esgotos sanitários. Vol.1: Abertura e fechamento de valas. Associação Brasileira de Engenharia Sanitária e Ambiental. Rio de Janeiro, RJ.

ABES (1979c). Manual do instalador de ramais prediais de esgotos sanitários. Vol.1: Abertura e fechamento de valas. Associação Brasileira de Engenharia Sanitária e Ambiental. Rio de Janeiro, RJ.

ABIKO, A.K. (1995). Serviços Públicos Urbanos. Texto Técnico da Escola Politécnica da USP. Departamento de Engenharia de Construção Civil. São Paulo: EPUSP. 21p.

ABNT - ASSOCIAÇÃO BRASILEIRA DE NORMAS TÉCNICAS. NBR 12266/92. Projeto e Execução de Valas para Assentamento de Tubulação de Água, Esgoto ou Drenagem Urbana . 
AUGUSTO JR., F.; GIAMPAGLIA, H.R.; CUNHA, M.A. (1992). Manual de Pavimentação Urbana. Instituto de Pesquisa Tecnológico. São Paulo, SP.

AL-SWAILMI, S. (1994). Framework for Municipal Maintenance Management Systems. Transportation Research Record 1442. TRB. National Reserch Council . Washington, D.C., p.03-10.

AMERICAN ASSOCIATION OF STATE HIGHWAY AND TRANSPORTATION OFFICIALS (1986). Aashto Guide for Design of Pavement Structures. Apêndice K: Tipical Pavement Distress Type-Severity Descriptions. Washington, D.C.

BALBO, J.T. (1997). Pavimentos Asfálticos: Patologias e Manutenção. São Paulo: Editora Plêiade.

BERTOLLO, S.A.M. (1997). Considerações sobre a gerência de pavimentos urbanos em nível de rede. 194p. Dissertação (Mestrado em Transporte) Escola de Engenharia de São Carlos, Universidade de São Paulo. São Carlos, SP.

CAREY, W.N.; IRICK, P.E. (1960). The Pavement Serviceability-Performance Concept. Highway Research Board Bulletin 250, p.40-58.

COMGAS (2004). Plano de Prevenção de Danos. Companhia de Gás de São Paulo. Departamento de Integridade de Ativos e Conformidade. São Paulo, SP.

EVANS, L.D.; MOJAB, C.G.; PATEL, A.J.; ROMINE, A.R.; SMITH, K.L.; WILSON, T.P. (1993). Innovative Materials Development and Testing. Vol.2: Pothole Repair. SHRP-H-353. Washington, D.C.

FERNANDES Jr., J.L. (1996). Sistemas de Gerência de Pavimentos. Apostila. Escola de Engenharia de São Carlos, USP, São Carlos. 
FERNANDES Jr., J.L. (1997). Considerações sobre a implementação de sistemas de gerência de pavimentos. $9^{\circ}$ Congresso Ibero-Latinoamericano del Asfalto. Asunción-Paraguay. Tomo 2, p.1123-1136.

FERNANDES Jr., J.L.; BERTOLLO, S.A.M. (1997). Considerações sobre a gerência de pavimentos urbanos em nível de rede. $9^{\circ}$ Congresso IberoLatinoamericano del Asfalto. Asunción-Paraguay. Tomo 2, p.1123-1136.

FERNANDES Jr., J.L.; MARGARIDO, S.A.; ZERBINI, L.F. (1996). Priorização em Sistema de Gerência de Pavimentos Urbanos. $7^{\mathrm{a}}$ Reunião de Pavimentação Urbana, ABPv, São José dos Campos, SP. p.327-342.

FERNANDES Jr., J.L.; ODA, S.A.; ZERBINI, L.F. (2001). Defeitos e atividades de manutenção e reabilitação em pavimentos asfálticos. Apostila. Escola de Engenharia de São Carlos, Universidade de São Paulo, São Carlos, SP.

FHWA (1989). Road Surface Management for Local Governments. Course Workbook. U. S. Department of Transportation. Federal Highway Administration. Austin, Texas, dec.

HAAS, R.; HUDSON, W.R.; ZANIEWSKI, J. (1994). Modern Pavement management. Krieger Publishing Co. Malamar, Florida.

IBGE - INSTITUTO BRASILEIRO DE GEOGRAFIA E ESTATÍSTICA. Censo 2000.. Disponível em: <http://www.ibge.gov.br>.

LIMA, J.P., LOPES, S.B., ZANCHETTA, F., ANELLI, R.L.S., FERNANDES Jr., J.L. (2004). Uso de SIG para Gerência de Infraetruturas de Transportes: Estudo de Caso em São Carlos-SP. In: Planejamento Integrado: em busca de desenvolvimento sustentável para cidades de pequeno e médio portes, 2004, Braga. Planejamento Integrado. 
MAPC (1986). Pavement Management - A Manual for Communities. U. S. Department of Transportation. Metropolitan Área Planning Council, Boston, MA.

MASCARÓ, J.L. (1994). Manual de Loteamentos e Urbanizações. Porto Alegre, SAGRA/D.C. Luzzatto, 1994.

MASCARÓ, J.L. (1987). Desenho urbano e custos de urbanização. Brasilia, MHU/SAM, 1987.

MASSARA, V.M. (2002). O perfil da infra-estrutura no Município de São Paulo e sua relação com as transformações de uso do solo: o centro expandido e a região de São Miguel Paulista. 178p. Dissertação (Mestrado) - Escola Politécnica da Universidade de São Paulo. Departamento de Engenharia de Construção Civil. São Paulo, SP.

MASI, A.; ALMEIDA, J.I.S. (1994). Interferência das Concessionárias de serviços Públicos na Pavimentação Urbana. $5^{a}$ Reunião de Pavimentação Urbana, ABPv, Natal, RN. p.330-346.

MISAWA, T.; FONSECA, E.A.M.; MARTINS, J.A.; MELLO, H.B.; SALOMON, J.B.F.; CECÍLIO, W. (1975). Construção de sistemas de distribuição de água. São Paulo: CETESB.

MOTTA, L.M.G. (1995). Considerações a Respeito de Pavimentos e Tráfego nas Vias Urbanas. 6 ${ }^{a}$ Reunião de Pavimentação Urbana, ABPv, Santos, SP. p.25-52.

NINA, E.D. (1966). Construção de redes urbanas de esgoto. Rio de Janeiro,1966. AO LIVRO TÉCNICO. 
PANTIGOSO, J.F.G. (1998). Uso dos sistemas de informação geográfica para a integração da gerência de pavimentos urbanos com as atividades das concessionárias de serviços públicos. 163p. Dissertação (Mestrado) Escola de Engenharia de São Carlos, Universidade de São Paulo. São Carlos, SP.

PAOLUCCI, H.V.N.; CARVALHO, J.C. (1995). A realidade da grande maioria de nossos pavimentos urbanos. 29a Reunião Anual de Pavimentação, ABPv, Cuiabá, MT. vol.2, p.432-463.

PENTEADO, S.R. (1994). Uma proposta para determinação de prioridades em transportes e infra-estruturas de pequenos municípios - o caso de Jaguariúna-SP. 109p. Dissertação (Mestrado) - Escola de Engenharia de São Carlos, Universidade de São Paulo. São Carlos, SP.

PUPPI, I.C. (1981). Estruturação Sanitária das Cidades. Curitiba, Universidade Federal do Paraná/São Paulo, CETESB.

SÃO CARLOS Oficial - A cidade: Geografia (2004). Disponível em: <http://www.saocarlosoficial.com.br/acidade/>. Acesso em: 13 jun

SHRP (1993a). Asphalt Pavement Repair Manual of Practice. The Strategic Highway Research Program. National Academy of Science. SHRP-H-348. Whashington, D.C.

SHRP (1993b). Distress Identification Manual for the Long-Term Pavement Performace Studies. The Strategic Highway Research Program. National Academy of Science. Whashington, D.C.

TONI, G. (1995). Informação Elimina Distâncias. Folha de São Paulo, São Paulo. 13-abril-95. Especial: A Era da Informação. 
ZANCHETTA, F. (2005). Aquisição de dados sobre a condição dos pavimentos visando a implementação de sistemas de gerência de pavimentos urbanos. 111p. Dissertação (Mestrado) - Escola de Engenharia de São Carlos, Universidade de São Paulo. São Carlos, SP.

ZHANG, Z.; DOSSEY, T.; WEISSMANN, J.; HUDSON, W.R. (1994). GIS Integrated Pavement and Infrastructure Management in Urban Areas. Transportation Research Record 1429. TRB. National Research Council. Washington, D.C., p.84-89.

ZMITROWICZ, W. (1997). Planejamento territorial urbano. Texto Técnico da Escola Politécnica da USP. Departamento de Engenharia de Construção Civil. São Paulo: EPUSP. 20p.

ZMITROWICZ, W.; ANGELIS NETO, G.D. (1997). Infra-estrutura urbana. Texto Técnico da Escola Politécnica da USP. Departamento de Engenharia de Construção Civil. São Paulo: EPUSP. 36p.

ZORZAL, F. M. B. (2003). Gerência de Cidades: Infra-estrutura - Com estudo de caso para a Cidade de Curitiba. Tese (Doutorado) - Universidade Federal de Santa Catarina, Programa de Pós-graduação em Engenharia de Produção. Florianópolis, SC.

ZUPPOLINI NETO, A.; MERIGHI, J.V.; FORTES, R.M. (1993). Controle de Qualidade em Obras de Pavimentação Urbana - Algumas Sugestões. $27^{a}$ Reunião Anual de Pavimentação, ABPv, Teresina, PI. vol.2, p.142-159.

ZUPPOLINI NETO, A. (1994). Pavimentação urbana no estado de São Paulo: novas considerações. 125p. Dissertação (Mestrado) - Escola de Engenharia de São Carlos, Universidade de São Paulo. São Carlos, SP. 